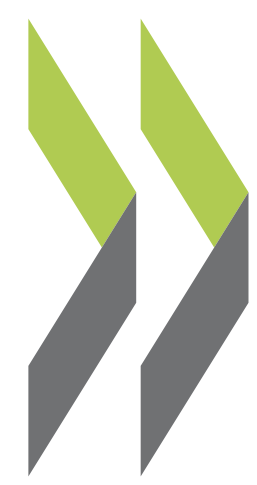

OECD Economics Department Working Papers No. 1450

\author{
Deepening regional \\ integration within \\ the Southern African \\ development community
} Falilou Fall, Boingotlo Gasealahwe 
Organisation de Coopération et de Développement Économiques

Organisation for Economic Co-operation and Development

11-Dec-2017

ECONOMICS DEPARTMENT

English - Or. English

\section{DEEPENING REGIONAL INTEGRATION WITHIN THE SOUTHERN AFRICAN DEVELOPMENT} COMMUNITY (SADC)

ECONOMICS DEPARTMENT WORKING PAPERS No. 1450

By Falilou Fall and Boingotlo Gasealahwe

OECD Working Papers should not be reported as representing the official views of the OECD or of its member countries. The opinions expressed and arguments employed are those of the author(s).

Authorised for publication by Alvaro Pereira, Director, Country Studies Branch, Economics Department.

All Economics Department Working Papers are available at www.oecd.org/eco/workingpapers

JT03424589

This document, as well as any data and map included herein, are without prejudice to the status of or sovereignty over any territory, to the delimitation of international frontiers and boundaries and to the name of any territory, city or area. 
OECD Working Papers should not be reported as representing the official views of the OECD or of its member countries. The opinions expressed and arguments employed are those of the author(s).

Working Papers describe preliminary results or research in progress by the author(s) and are published to stimulate discussion on a broad range of issues on which the OECD works.

Comments on Working Papers are welcomed, and may be sent to OECD Economics Department, 2 rue André-Pascal, 75775 Paris Cedex 16, France, or by e-mail to eco.contact@ oecd.org.

All Economics Department Working Papers are available at www.oecd.org/eco/workingpapers.

This document and any map included herein are without prejudice to the status of or sovereignty over any territory, to the delimitation of international frontiers and boundaries and to the name of any territory, city or area.

The statistical data for Israel are supplied by and under the responsibility of the relevant Israeli authorities. The use of such data by the OECD is without prejudice to the status of the Golan Heights, East Jerusalem and Israeli settlements in the West Bank under the terms of international law.

ou can copy, download or print OECD content for your own use, and you can include excerpts from OECD publications, databases and multimedia products in your own documents, presentations, blogs, websites and teaching materials, provided that suitable acknowledgment of OECD as source and copyright owner is given. All requests for commercial use and translation rights should be submitted to rights@oecd.org 
ECO/WKP(2017)82

\section{ABSTRACT/RÉSUMÉ}

\section{Deepening regional integration within the Southern African Development Community (SADC)}

Deepening regional integration within the Southern African Development Community (SADC) will raise potential growth for all member countries. Integrated economies will increase market size, trade opportunities and improve resource allocation across member countries. Key pillars of functioning regional integration are the free circulation of goods and services, mobility of workers and interconnected infrastructure. To boost regional integration, remaining tariff barriers and non-tariffs barriers should be removed. Ensuring greater compliance to agreements by SADC members will also facilitate intra-regional trade and cross-investments. More co-operation between competition authorities should facilitate harmonisation of competition rules in particular in services and transport-related services which would ease circulation of good and services. The other key pillars of regional integration (industrial policy, infrastructure, investment, financial integration and tax) are also reviewed.

This Working Paper relates to the 2017 OECD Economic Survey of South Africa (http://www.oecd.org/eco/surveys/economic-survey-south-africa.htm).

JEL classification: F13, F15, F53, O24, O25

Keywords: South Africa, regional integration, SADC, trade, trade agreements, infrastructure

\section{Approfondir l'intégration régionale de la Communauté de Développement d'Afrique Australe}

L'approfondissement de l'intégration régionale dans la Communauté de développement d'Afrique australe augmentera la croissance potentielle pour tous les pays membres. Les économies intégrées augmenteront la taille du marché, des opportunités commerciales et amélioreront l'allocation des ressources parmi les pays membres. Les piliers clés d'une intégration régionale fonctionnelle sont la libre circulation des biens et services, la mobilité des travailleurs et des infrastructures interconnectées. Pour stimuler l'intégration régionale, les barrières tarifaires et non tarifaires restantes devraient être éliminées. Assurer un plus grand respect et une meilleure application des accords par les états membres faciliteraient le commerce intra régional et les investissements croisés. Une plus grande coopération entre les autorités de concurrence des différents pays faciliterait l'harmonisation des règles concurrentielles, en particulier celles concernant les services et les services liés au transport pour une meilleure circulation des biens. Les autres piliers clés de l'intégration régionale (politique industrielle, l'investissement, l'intégration financière et la taxation) sont également analysés.

Ce Document de travail se rapporte à l'Étude économique de l'OCDE de l'Afrique du Sud 2017 (http://www.oecd.org/fr/eco/etudes/etude-economique-afrique-du-sud.htm).

Classification JEL: F13, F15, F53, O24, O25

Mots clefs: Afrique du Sud, intégration régionale, commerce, accord commercial, infrastructure, Communauté de développement d'Afrique australe 


\section{TABLE OF CONTENTS}

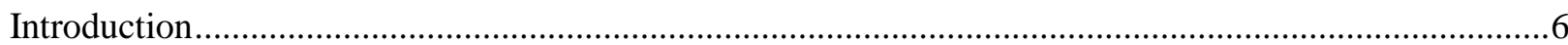

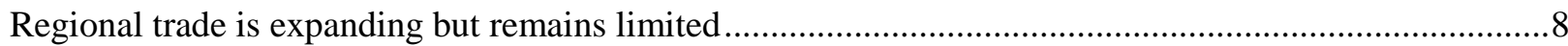

SADC intra-regional trade is low compared to other regional communities .........................................8

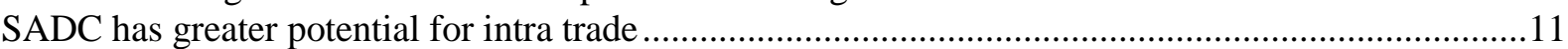

Greater participation in regional value chains could boost intra-trade................................................11

The development of regional value chains is hindered by structural factors .......................................13

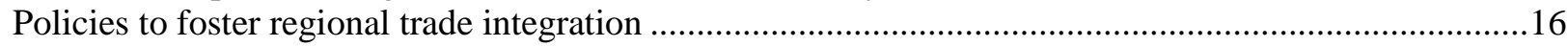

Strengthening the institutional framework to achieve SADC objectives .............................................16

Reducing tariffs and non-tariff barriers would foster regional trade integration ...................................17

Broadening the scope of the trade agreements could boost regional trade and integration ...................20

Reforming the Southern African Customs Union (SACU) to foster regional integration ......................26

Reforming the enabling environment to strengthen regional integration ..............................................27

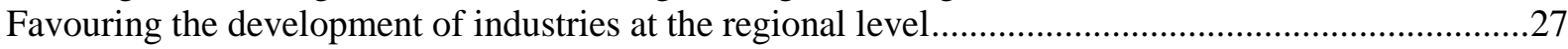

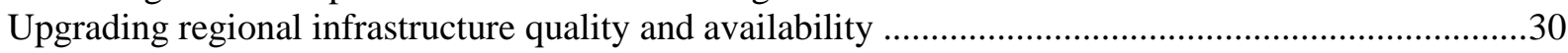

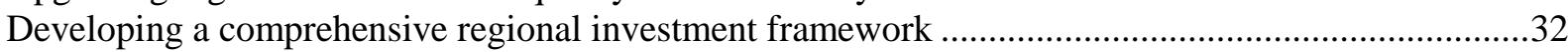

Further integration of the financial system will ease financing conditions across countries ..................35

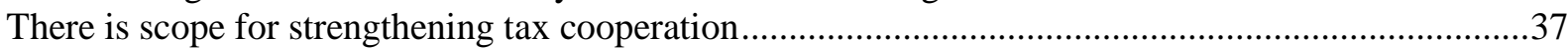

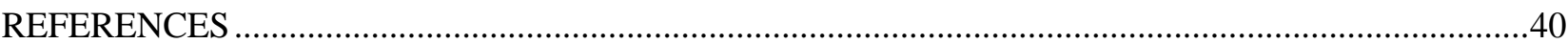

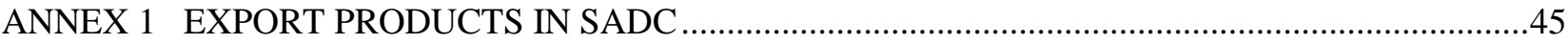

ANNEX 2 ESTIMATES OF DETERMINANTS OF TRADE FLOWS ….............................................46

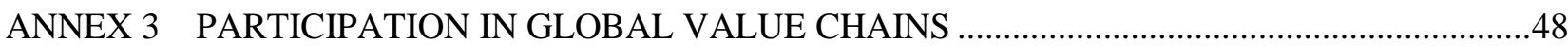

ANNEX 4 ROAD INFRASTRUCTURE NEEDS IN SADC ..............................................................50

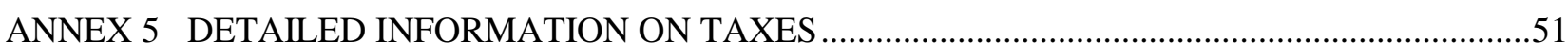

\section{Tables}

Table 1. Revealed comparative advantages of top 10 export products of SADC countries ......................10

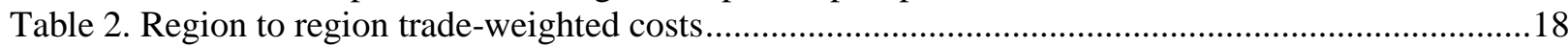

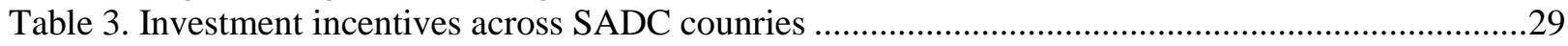

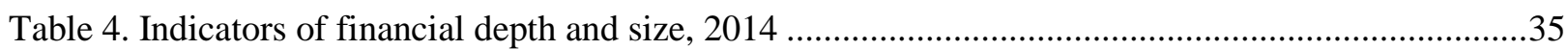

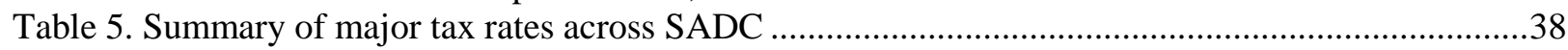

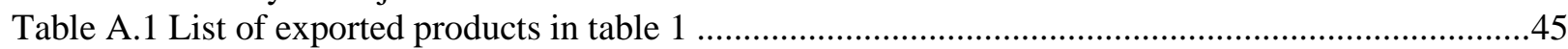

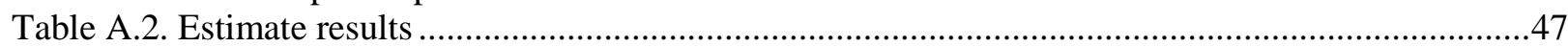

Table A.3. The origin of value added in exports - backward participation, .............................................48

Table A.4 Destination of value added used by trading partners for exports ............................................49 


\section{Figures}

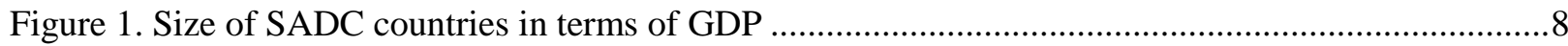

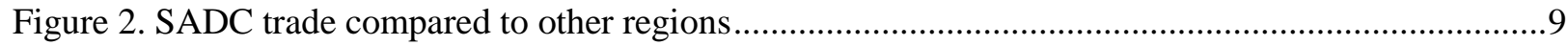

Figure 3. Intra and extra-regional participation in Global Value Chains ................................................12

Figure 4. GVC participation and contribution to trade policies .............................................................13

Figure 5. First-tier suppliers in SADC and their headquarters............................................................

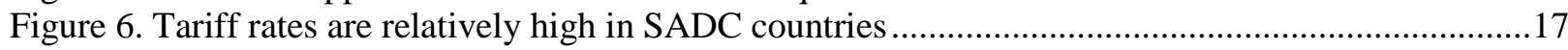

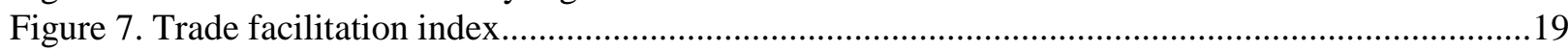

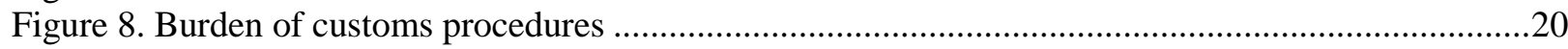

Figure 9. Service export is sizeable in many SADC countries .......................................................21

Figure 10. Restrictions on foreign provision of some services are high relative to other countries ..........22

Figure 11. Trade between SADC and the European Union ................................................................26

Figure 12. Contribution of SACU revenue to member countries' government budget, 2014/15 .............27

Figure 13. Degree of industrialisation and competitiveness of SADC countries....................................28

Figure 14. Transport infrastructure compared to OECD average .......................................................... 31

Figure 15. SADC experienced a rapid increase of inward investment over the past 15 years...................32

Figure 16. FDI position of SADC relative to other regional economic communities ................................34

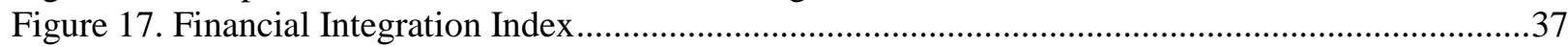




\title{
DEEPENING REGIONAL INTEGRATION WITHIN THE SOUTHERN AFRICAN DEVELOPMENT COMMUNITY (SADC)
}

\author{
by Falilou Fall and Boingotlo Gasealahwe ${ }^{1}$
}

\section{Introduction}

South Africa has been an active participant of regional partnerships in Southern Africa. Deeper regional integration can raise potential growth and create more quality jobs in participating countries. Key pillars are free circulation of goods and services, mobility of workers and interconnected infrastructure. Regional economic integration can be particularly beneficial in Southern Africa, where seven out of 15 countries are landlocked and fragmentation into many small countries is important. Greater integration brings larger markets, more jobs, more trade opportunities, and higher productivity from better resource allocation across member countries (Schiff and Winters, 2003). South Africa has been identified as gaining from greater trade and as being a key driver of regional value chains as a market and as a source of inputs (AfDB et al. 2014). However, it can take time to strengthen integration and develop regional policies to overcome national interests and barriers.

The Southern African Development Community (SADC) was established in 1992 with strong political commitments to integration (Box 1). SADC initially has prioritised trade and after long negotiation a free trade area was completed in 2008 with tariffs eliminated on $85 \%$ of traded goods among 13 of the 15 members. Angola and the Republic Democratic Congo are still outside the free trade area. South Africa, the largest member (Figure 1), has also formed a customs union, SACU, with some members of the SADC, and a monetary union with Lesotho, Namibia and Swaziland. South Africa has also been active in developing pan-African integration that aims at unifying various existing trade agreements.

In practice, economic integration in the SADC has been slow. Integration has not been able to overcome domestic structural constraints such as small market size, skills constraints, undiversified economies, or sectoral policies that protect certain industries such as automobiles or textiles. Also, national policies have remained more important than regional ones for the members explaining slow progress towards fuller regional integration. In recent years, SADC aimed at reviving integration among members by adopting a Revised Regional Indicative Strategic Development Plan for 2015-2020, which contains a clear vision for greater regional integration and sectoral strategies. South Africa should take the leadership in implementing agreed agreements and protocols and in strengthening the institutional framework.

This article focuses on SADC, which is South Africa's most important and growing market, and where further integration can have an important boost to growth for its members. It assesses the state of the key pillars of the SADC regional integration process to identify remaining bottlenecks for deeper integration and policy recommendations. The first section assesses the degree of trade integration and its potential as trade has been the most important element of integration, so far. The second section analyses

1. Falilou Fall is a Senior Economist at the OECD Economics Department (falilou.fall@oecd.org). Boingotlo Gasealahwe was on secondment from the South African National Treasury when working on this paper. The authors would like to thank Aida Caldera Sanchez, Christine Lewis, Robert Ford, Alvaro Pereira and Piritta Sorsa (Economics Department), Iris Mantovani and Iza Lejarraga (directorate for Financial and Enterprise Affairs), Charles Cadestin (Directorate for Trade and Industry), Ania Thiemann (Directorate for Financial and Enterprise Affairs), Bert Brys (Centre for Tax Policy and Administration) for useful comments on earlier drafts and helpful contributions. The paper has also benefitted from comments by South African officials and by members of the OECD Economic Development Review Committee. Special thanks go to Taejin Park and Pedro Herrera Gimenez for statistical assistance and Anthony Bolton, Raquel Paramo and Heloise Wickramanayake for editorial assistance (all from the Economics Department). 
the institutional framework and the principal remaining trade barriers and provides recommendations to boost regional trade integration. The last section covers the other key pillars (industrial policy, infrastructure, investment, financial integration and tax) of regional integration.

\section{Box 1. History of Regional Integration in Southern Africa}

SADC: Close collaboration among Southern African countries started already in 1975 when Angola, Botswana, Mozambique, Tanzania and Zambia were meeting regularly to coordinate effort, resources and support to the different liberation movements in the region. In April 1980 in Lusaka (Zambia) the nine independent states of Southern Africa - Angola, Botswana, Lesotho, Malawi, Mozambique, Swaziland, Tanzania, Zambia and Zimbabwe created the Southern African Development Coordination Conference (SADCC) to reduce economic dependence on South Africa and enhance regional integration. In 1992, at Windhoek (Namibia) the member countries decided to transform "SADCC" from a coordination conference into SADC, the Community. Specifically, they decided to move from an association into a legally binding arrangement. The economic dimension was put forward with the aim to deepen economic co-operation and integration. Membership increased to 15 with the accession of Namibia in 1990, South Africa in 1994, Mauritius in 1995, Seychelles and the Democratic Republic of Congo in 1997, and Madagascar in 2005.

SACU. The Southern African Customs Union (SACU) was established in 1910 between the Union of South Africa and the three so-called High Commission Territories of Bechuanaland (now Botswana), Basutoland (now Lesotho) and Swaziland. A new agreement was signed in 1969 between South Africa, Botswana, Lesotho and Swaziland. Namibia joined SACU in 1990 upon its independence from South Africa. The SACU Agreement was renegotiated in 2002 and entered into force in 2004.

The three main features of SACU are: the free movement of goods and services between member countries; the common external tariff; and revenue sharing of the common pool of duties and trade taxes. The revenue-sharing formula has three components: custom, excise and development. The custom revenue is distributed on the basis of each country's share in intra-SACU imports. The excise distribution depends on each country's share of GDP. The development component, which is fixed at $15 \%$ of total excise revenue, is distributed according to the inverse of each country's GDP per capita.

Tripartite Free Trade Area (TFTA). A Tripartite Free Trade Area initiative was launched in 2008 between members of the East African Community (EAC), Common Market for Eastern and Southern Africa (COMESA) and Southern African Development Community (SADC). A complementary objective was to solve the complications created by overlapping membership of the different regional economic communities. All members belong to more than one FTA, for instance, eight members of COMESA are simultaneously members of SADC. Overlapping membership creates legal uncertainty, unnecessary costs, and delays in the implementation of reforms.

After four years of negotiations, the TFTA was signed in June 2015 by 24 countries. However, South Africa and SACU members have not signed. The parties committed to conclude outstanding issues on rules of origin, trade remedies and tariff offers by June 2016. However, the deadline was not met, and the start of Phase II negotiations trade in services and other trade-related matters - has been delayed waiting for the conclusion of negotiations on Phase I.

Source: the Regional Indicative Strategic Development Plan (2002) and http://www.sadc.int/about-sadc/overview/history-and-treaty/ 
Figure 1. Size of SADC countries in terms of GDP

A. Share of SADC GDP volume, 2015

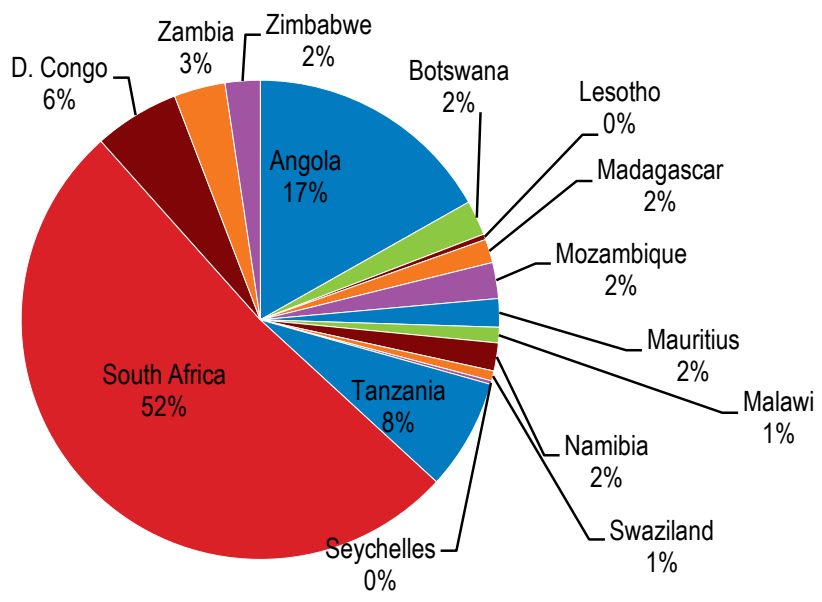

B. GDP per capita, 2015

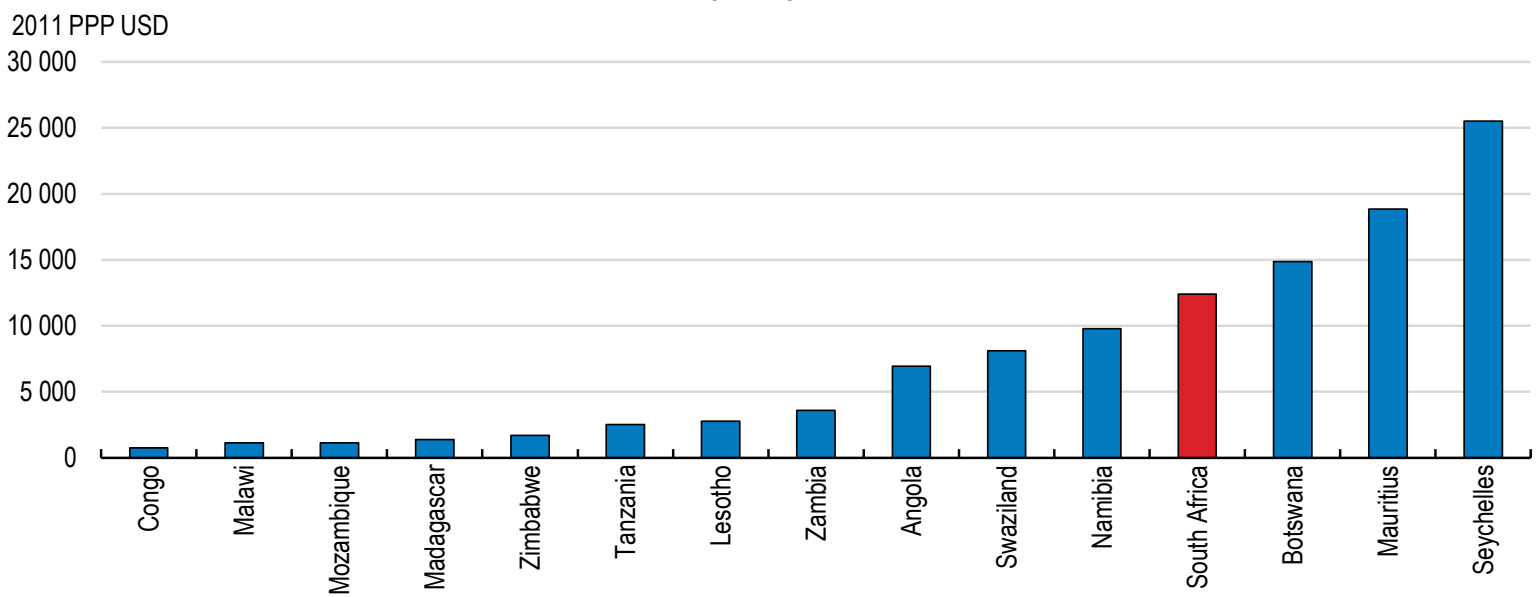

Source: World Bank World Development Indicators database.

\section{Regional trade is expanding but remains limited}

\section{SADC intra-regional trade is low compared to other regional communities}

Intra-regional trade in the SADC is only $10 \%$ of the regional total exports compared to about $25 \%$ in the ASEAN or $40 \%$ in the European Union (Figure 2). This is similar to ECOWAS in Africa and somewhat below MERCOSUR. SADC intra-regional trade has increased only modestly since the establishment of the free trade area in 2008 (Figure 2, Panel A). SADC trade is also dominated by its largest member, South Africa, which accounts for about half of the group's GDP (Figure 1). This makes SADC trade closely dependent on South Africa's economy and interest in fostering more co-operations with SADC countries. South Africa's imports from SADC are low compared to its exports toward SADC countries which creates a structural trade imbalance with the regional partners (Figure 2, Panel B). Thus, SADC region is a non-negligible market for South Africa. 
Figure 2. SADC trade compared to other regions

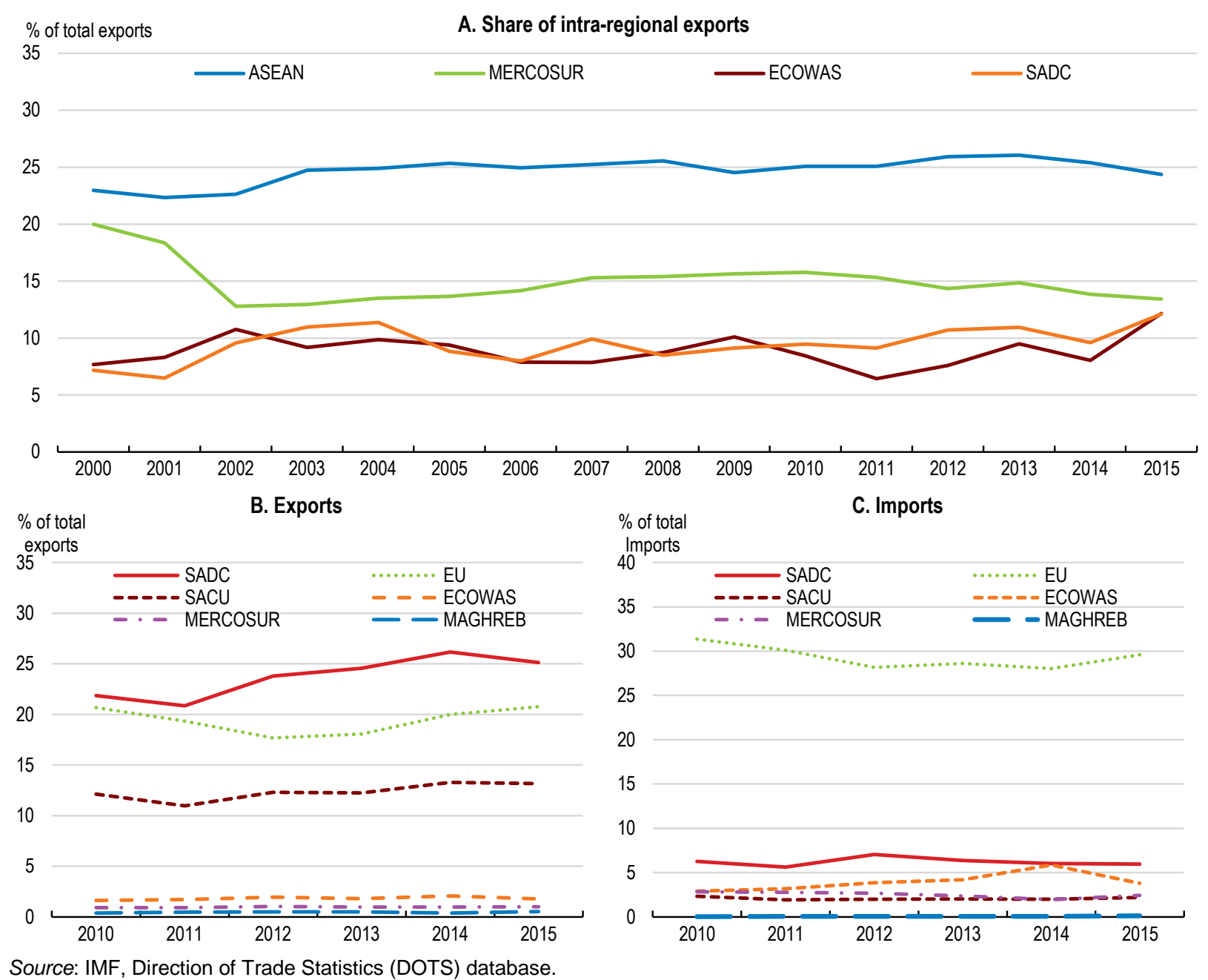

The relatively weak performance of SADC intra-trade is, in part, explained by the similar economic structures of its members. However, similarity of products or endowments should not limit trade because countries have different costs of production for the different products and therefore different comparative advantages. Tariffs and non-tariffs barriers are rather the obstacle to trade developments (see below). Only five of the members have a revealed comparative advantage (over 100), at the world level in one product (Table 1). Their exports are also dominated by non-processed goods, such as crops, minerals and other natural resource products.

Few countries are exporting manufactured or sophisticated industrial products (Table 1). This also limits potential for intra-industry trade in which similar or slightly differentiated goods or services (e.g. quality or choice), often manufactures, are exchanged between countries (Krugman, 1979 and 1980). Therefore, trade in manufactured goods between member countries rest on differences in costs of production. For instance, ten out of the fifteen countries are exporting natural or cultured pearls, precious or semi-precious stones, and precious metals in their top 10 export products. Manufacturing exports are also very similar, for instance machinery and mechanical appliances. Estimations by Fall et al. (2014) show that while the development of manufacturing increased intra-regional trade in ECOWAS, it had negative effects in SADC, confirming the low complementarity of SADC countries. The difference of 
manufacturing effects on intra-trade between SADC and ECOWAS is explained by the impact of Nigeria, ECOWAS leader, which produces more manufacturing goods for the region.

Table 1. Revealed comparative advantages of top 10 export products of SADC countries

\begin{tabular}{|c|c|c|c|c|c|c|c|}
\hline \multicolumn{2}{|r|}{ Angola } & \multicolumn{2}{|r|}{ Botswana } & \multicolumn{2}{|r|}{ Congo } & \multicolumn{2}{|r|}{ Lesotho } \\
\hline RCA & Product & $\mathrm{RCA}$ & Product & RCA & Product & $\mathrm{RCA}$ & Product \\
\hline 8.5 & Mineral fuels, oils (1) & 32.5 & Nickel & 127.0 & Other base metals & 36.2 & Wood \\
\hline 0.9 & Pearls, precious stones & 22.2 & Pearls, precious stones & 62.7 & Copper & 20.4 & Apparel and clothing (1) \\
\hline 0.2 & Fish and crustaceans & 2.6 & Meat & 19.5 & Ores & 12.6 & Apparel and clothing (2) \\
\hline 0.1 & Salt; sulphur & 1.5 & Salt; sulphur & 7.3 & Inorganic chemicals & 11.0 & Products milling industry \\
\hline 0.0 & Wood & 0.9 & Ores & 2.4 & Wood & 9.2 & Pearls, precious stones \\
\hline \multirow[t]{5}{*}{0.0} & Coffee, tea & 0.8 & Inorganic chemicals & 1.0 & Pearls, precious stones & 6.7 & Cotton \\
\hline & & 0.1 & Electrical machinery & 0.9 & Coffee, tea & 3.4 & Articles of leather \\
\hline & & 0.1 & Plastics & 0.8 & $\begin{array}{l}\text { Cocoa and cocoa } \\
\text { preparations }\end{array}$ & 1.7 & Footwear \\
\hline & & 0.1 & Vehicles & 0.5 & Mineral fuels, oils & 1.2 & Furniture; bedding \\
\hline & & 0.1 & Machinery and nuclear reactors & 0.5 & Commodities (3) & 0.3 & Electrical machinery \\
\hline \multicolumn{2}{|r|}{ Madagascar } & \multicolumn{2}{|r|}{ Malawi } & \multicolumn{2}{|r|}{ Mauritius } & \multicolumn{2}{|r|}{ Mozambique } \\
\hline RCA & Product & RCA & Product & RCA & Product & RCA & Product \\
\hline 31.3 & Nickel & 28.6 & Tobacco & 27.3 & Knitted fabrics & 21.3 & Aluminium \\
\hline 30.3 & Coffee, tea & 17.2 & Dairy produce & 22.3 & Prep. of meat, fish & 5.7 & Tobacco \\
\hline 13.6 & Apparel and clothing (1) & 12.3 & Edible vegetables & 20.9 & Apparel and clothing & 5 & Cotton \\
\hline 12.4 & Apparel and clothing (2) & 11 & Coffee, tea & 20.4 & Apparel and clothing (2) & 4.6 & Sugars \\
\hline 7.9 & Cotton & 10.7 & Sugars & 10.6 & Sugars & 2.9 & Wood \\
\hline 6.2 & Other base metals & 9.2 & Cotton & 7.5 & Cotton & 1.1 & Mineral fuels, oils \\
\hline 4 & Edible vegetables & 8.4 & Residues food indust. & 6.6 & Electrical machinery & 0.7 & Ores \\
\hline 4 & Fish and crustaceans & 6.3 & Fertilisers & 4.9 & Fish and crustaceans & 0.6 & Edible fruit, nuts \\
\hline 0.5 & Ores & 3.4 & Plastics & 0.6 & $\begin{array}{l}\text { Machinery and nuclear } \\
\text { reactors }\end{array}$ & 0.3 & $\begin{array}{l}\text { Machinery and nuclear } \\
\text { reactors }\end{array}$ \\
\hline \multirow[t]{2}{*}{0.1} & Mineral fuels, oils & 1 & Machinery and nuclear reactors & 0.5 & Pearls, precious stones & 0.2 & Pearls, precious stones \\
\hline & Namibia & & Seychelles & & South Africa & & Swaziland \\
\hline RCA & Product & RCA & Product & RCA & Product & $\mathrm{RCA}$ & Product \\
\hline 38 & Zinc & 104.3 & Preparations meat, fish & 2.1 & Vehicles & 39.4 & Essential oils \\
\hline 18.7 & Live animals & 29.6 & Commodities (3) & 2 & Iron and steel & 24.6 & Sugars \\
\hline 15.2 & Fish and crustaceans & 5.6 & Aircraft, spacecraft & 1.9 & $\begin{array}{l}\text { Machinery and nuclear } \\
\text { reactors }\end{array}$ & 20.1 & Printed books, newspapers \\
\hline 9.1 & Inorganic chemicals & 5.2 & Residues food industries & 1.8 & Edible fruit, nuts & 19.9 & Other chemical products \\
\hline 8.8 & Meat & 4.7 & Ships, boats & 1.8 & Beverages, spirits & 8.6 & Wood \\
\hline 2.2 & Pearls, precious stones & 1.6 & Tobacco & 1.6 & Ores & 7.8 & Apparel and clothing (2) \\
\hline 1.5 & Copper & 1.3 & Optical, photographic & 1.4 & Electrical machinery & 4.5 & Prep. of vegetables, fruit \\
\hline 0.8 & Edible fruit, nuts & 1.3 & Animal or vegetable fats and oils & 1.1 & Aluminium & 2.9 & Apparel and clothing (1) \\
\hline 0.7 & Ores & 1.2 & Fish and crustaceans & 1 & Pearls, precious stones & 2.8 & Organic chemicals \\
\hline 0.1 & Mineral fuels, oils & 1 & Mineral fuels, oils & 0.4 & Mineral fuels, oils & 1.8 & Beverages, spirits \\
\hline
\end{tabular}


Table 1. Revealed comparative advantages of top 10 export products of SADC countries contd

\begin{tabular}{|c|c|c|c|c|c|}
\hline \multicolumn{2}{|r|}{ Tanzania } & \multicolumn{2}{|r|}{ Zambia } & \multicolumn{2}{|r|}{ Zimbabwe } \\
\hline RCA & Product & $\mathrm{RCA}$ & Product & RCA & Product \\
\hline 13.9 & Edible vegetables & 11.7 & Copper & 20.6 & Tobacco \\
\hline 12.7 & Animal or vegetable fats & 6.9 & Cereals & 8.9 & Cotton \\
\hline 10.4 & Residues food industries & 3.1 & Salt; sulphur & 4.5 & Salt; sulphur \\
\hline 6.5 & Coffee, tea & 2.3 & Sugars & 4.4 & Sugars \\
\hline 3.8 & Fish and crustaceans & 1.5 & Other base metals & 2.2 & Wood \\
\hline 3.3 & Electrical machinery & 1.1 & Inorganic chemicals & 2.1 & Pearls, precious stones \\
\hline 3.1 & Tobacco & 1 & Tobacco & 1.8 & Iron and steel \\
\hline 2.1 & Edible fruit and nuts & 0.4 & Machinery and nuclear reactors & 1.4 & Coffee, tea \\
\hline 1.7 & Pearls, precious stones & 0.2 & Pearls, precious stones & 1.3 & Ores \\
\hline 1.3 & Ores & 0.1 & Mineral fuels, oils & 0.1 & Mineral fuels, oils \\
\hline
\end{tabular}

Note: (1) See Table A.1 in Annex 1 for the full name of products. (2): not knitted or crocheted; (3): not elsewhere specified.

Source: OECD calculation based on data from IMF, Direction of Trade Statistics (DOTS).

\section{SADC has greater potential for intra trade}

Trade impact and potential can be assessed by estimates of gravity equations of bilateral trade which explain trade flows generally well based on distance and size of countries (Tinbergen 1962, Head and Mayer 2015). The data used for the analysis cover bilateral trade flows from 1984 to 2014 and 189 countries and, most of the free trade areas in the world (see Annex 1 and Cadestin and Fall, 2017).

The estimations indicate that most of the free trade areas in the world have boosted trade. Bilateral trade for SADC members has increased by $62 \%$ by the free trade agreement. For the EU, the effect is $90 \%$ and for the Andean Community 141\% over the period (Annex 1, Table 2, Column 2). These results are encouraging for deepening SADC regional integration as they suggest that there is scope to further boost trade in the region. Distance and language proximity are factors favourable to regional trade. Estimations suggest that tariffs and non-tariff measures have hold down trade between SADC members (Cadestin and Fall, 2017).

\section{Greater participation in regional value chains could boost intra-trade}

Many emerging countries have boosted trade by participating in global or regional value chains (Kowalski et al., 2015). SADC countries are more integrated in global value chains (GVC) than in regional ones. Most of the foreign value added embedded in exports comes from outside the region (Figure 3, Panel A). Moreover, the intra-regional value added embedded in SADC members' exports decreased between 2000 and 2013, while it increased in Latin American and South-East Asian regional arrangements. The overall backward GVC participation of SADC is also low compared to South-East Asian, Latin American, Central Asian and European countries.

Deepening regional integration in SADC will depend partly on the capacity of member countries to increase their sourcing in the region to create more value for exports. This requires access to products at competitive conditions and prices. The origin of exported value added in SADC is mainly domestic (80\%) reflecting the dominance of raw materials in their exports. It peaks at $92 \%$ for Angola (oil exporter) and 87\% for Mozambique (minerals) (Table A.3 in Annex 3). The most diversified economies, Mauritius, or most integrated, Lesotho and Swaziland (both members of the SACU customs union with South Africa), have more foreign value added in their exports. 
Forward GVC participation, or share of a country's value added in exports of partners, of SADC countries is high just below the MENA, West and Central African, and Central Asia and European countries (Figure 1.3, Panel B). This also reflects the specialisation of SADC countries in exports of raw materials (oil and minerals). South-East Asian countries, and to a lesser extent Latin American countries, have more intra-regional forward GVC participation. South Africa is the only country using significant part of SADC value added in its exports (Table A.3 in Annex 3).

Figure 3. Intra and extra-regional participation in Global Value Chains
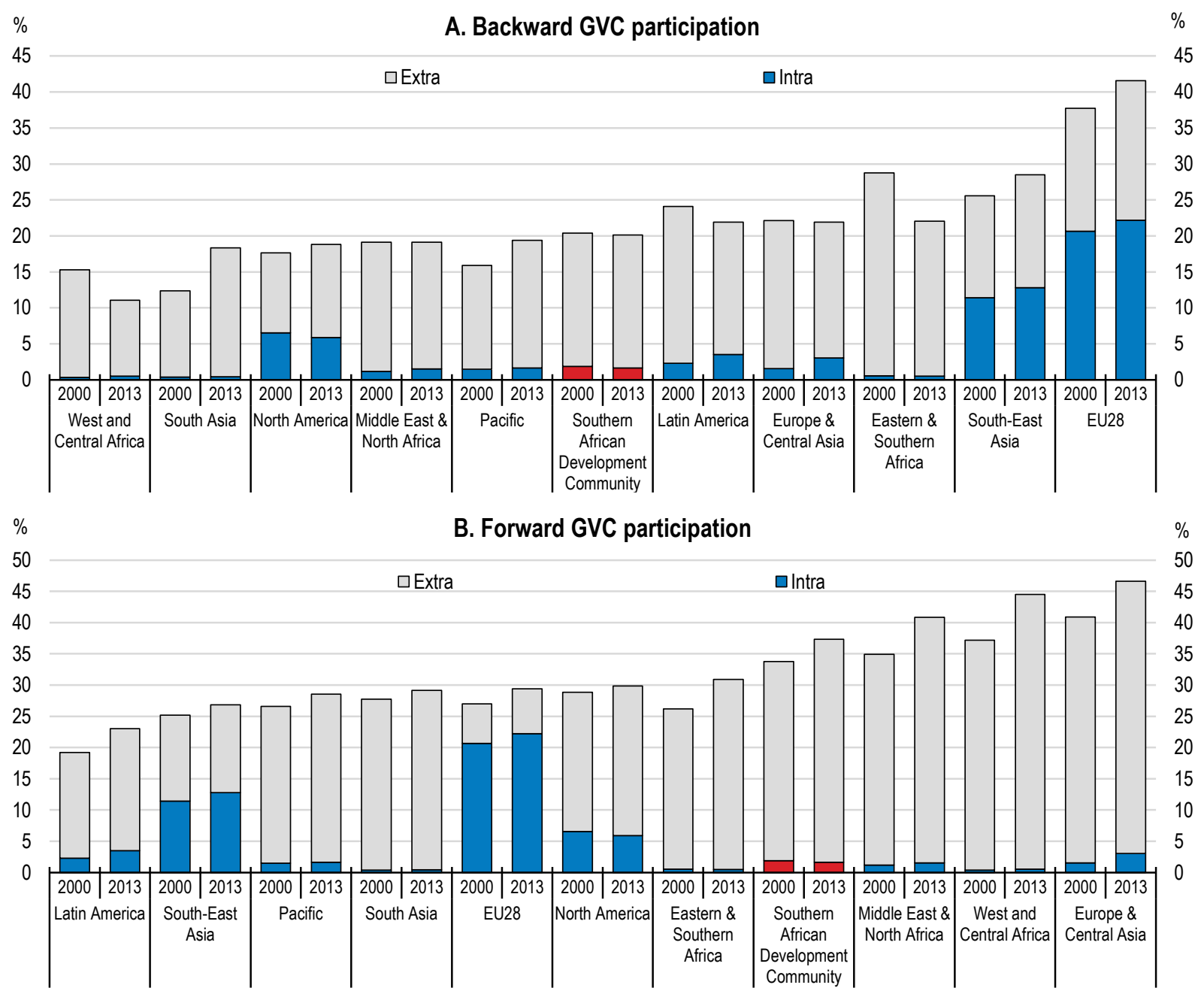

Source: OECD calculation based on EORA database.

The relatively low GVC participation of SADC countries is influenced to some extent by trade policies (tariffs and share of imports covered by free trade areas). Estimations of the determinants of low GVC participation show that for most SADC countries, trade policies contribute negatively to backward GVC participation (Figure 4, Panel A and Kowalski et al., 2015). However, trade policies in some countries (Mozambique, Angola, Zambia and South Africa) seem to be more favourable to forward GVC participation. 
Figure 4. GVC participation and contribution to trade policies

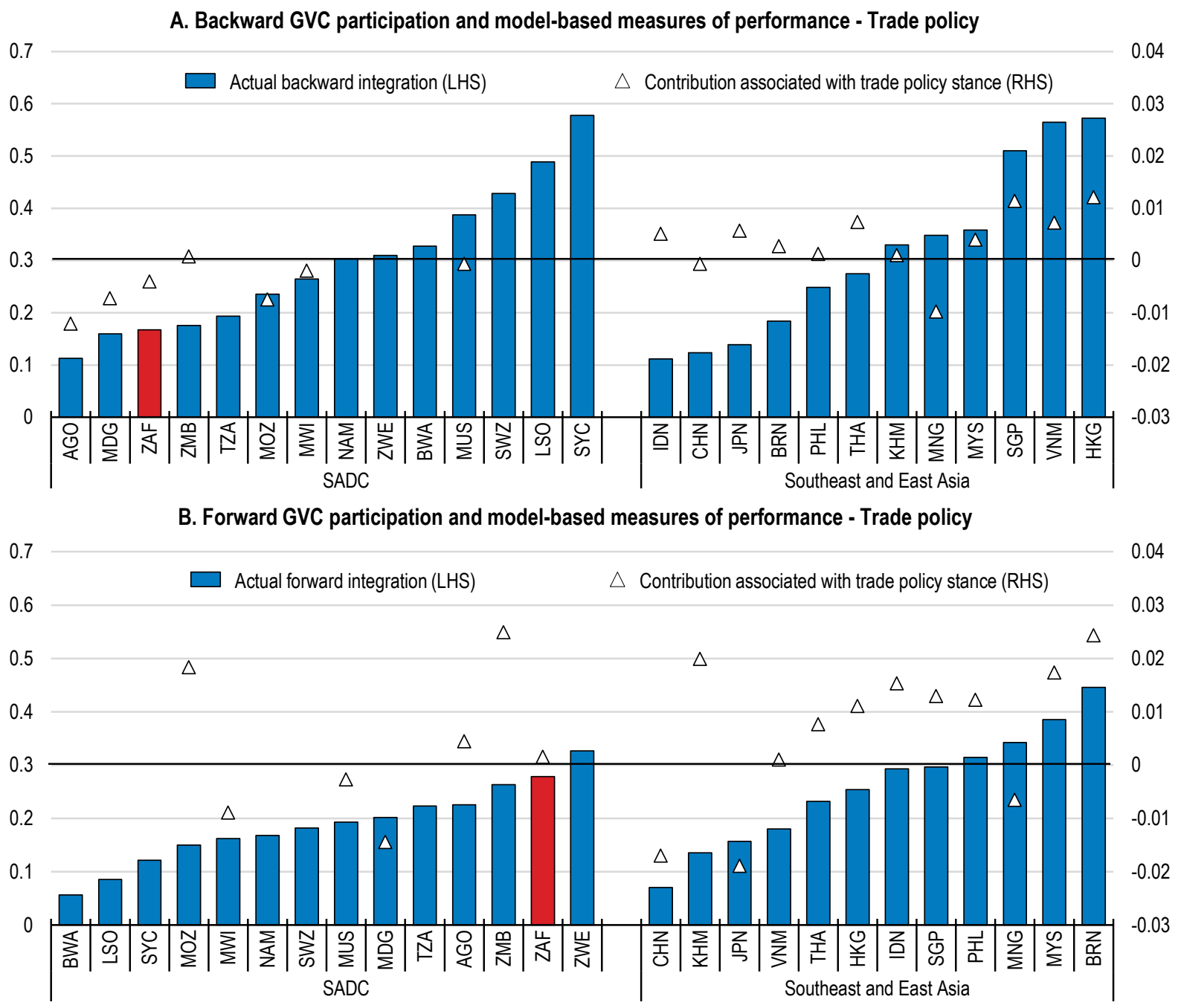

Source: OECD calculations based on EORA database.

\section{The development of regional value chains is hindered by structural factors}

The low development of regional value chains reflects the tendency of the governments to develop and follow the similar industrial and sectoral strategies. As with global value chains, the development of regional value chains is also influenced by trade and protectionist policies. To illustrate these issues value chains are discussed below with examples of three industries.

\section{Car industry value chain: an industry limited by regional market size}

The automobile value chain is analysed with firm-level supply chain data (FactSet, 2016) and business interviews with seven car manufacturers and two truck manufacturers with plants in South Africa (OECD, 2017a ). Interviews with industry representatives suggest that the automobile value chain in SADC is concentrated in South Africa. At the same time, South African plants are a small share in total world volumes of car production: 50000 vehicles compared to around a million in the producers' home 
countries and up to 10 million globally. The main players in SADC are global carmakers through affiliates in South Africa producing for the SADC market.

Carmakers source around $45-55 \%$ of components locally, primarily from large international component suppliers that have presence in South Africa. However, given low sales volumes in the region, many first-tier component suppliers are not able to locate in SADC, and the remaining components are sourced from their plants elsewhere in the world. The few components produced in the region tend to be simple. Multinational first-tier suppliers of car manufacturers have established subsidiaries in eight SADC countries. Local linkages are limited and only South Africa has some domestically owned first-tier suppliers, which produce around 50\% of auto parts and components (OECD, 2017a).

Globally car production tends to be close to the target market, influenced by low wages, availability of skilled workers and accessible infrastructure. The development of the car industry in SADC is limited by the absence of a big enough market or the inability of the car industry to design a "low cost" and competitive car for the regional market. The South Africa government provides a strong support for the development of the car industry mainly based on tax exemptions. Revising this policy to incentivise the car industry toward a more market based development strategy targeting regional markets would allow for higher volumes of production and as a result make SADC more attractive to foreign investors.

Figure 5. First-tier suppliers in SADC and their headquarters

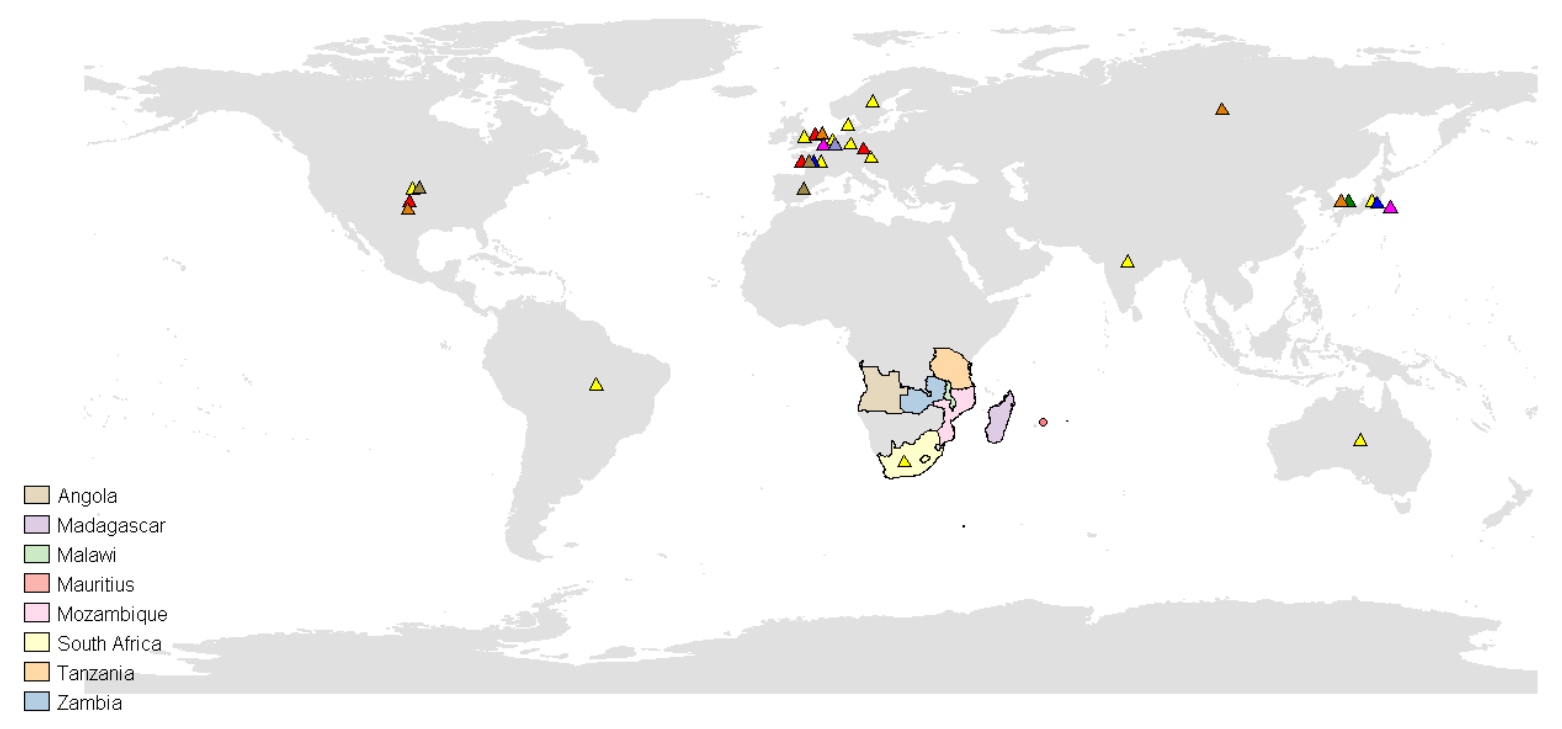

Note: Triangles represent the locations of the headquarters of first-tier suppliers, and shaded areas reflect affiliates within the SADC region. For instance, all yellow triangles are headquarters of firms that operate in South Africa.

Source: OECD report on "Regional Global Value Chains in SADC," 2017, forthcoming; calculations based on FactSet Supply Chain (2016).

\section{Textile and garment value chain: a development limited by regional trade policies}

The global textile and garment value chain has four core segments: (1) natural and synthetic fibres; (2) textiles; (3) garments; and (4) retail. The value chain is led by the retail sector: branded merchandisers are involved in global sourcing as lead buyers. The retail stage is concentrated into large, lean retail organisations. While the garment retail sector is relatively concentrated, with 38 multinationals accounting for $70 \%$ of global revenues, garment manufacturing is highly competitive, relies heavily on low-skilled labour and has low profit (OECD, 2017a). 
South Africa has a mature textile and garment industry dating back to a few businesses that started out in the 1920s. The industry developed initially under the high protection and import substitution of the Apartheid regime. It produced mainly for the domestic market, with limited exports in niche products. The development of the textiles and garments industry in SADC more generally was influenced by the MultiFibre Agreement (MFA) and subsequent WTO Agreement on Textiles and Clothing (ATC), which governed world trade in textiles and garments from 1974 through 2004. These agreements imposed quotas on garments imports from China, India and Pakistan to protect the textile industries in the United States and Europe. By limiting competition from Chinese and Indian imports, the Agreement helped the less competitive garment manufacturers in SADC to be competitive in their local markets. An unintended result of the Agreement was that Asian garment manufacturers constrained by the quotas relocated to countries in SADC (as well as other countries with no or underutilised quotas) to circumvent the quotas.

Legislation granting African countries preferential export access to the United States in 2000, the African Growth and Opportunity Act (AGOA), further bolstered the development of the garment industry in SADC, particularly in Lesotho, Mauritius, Madagascar and Swaziland. In South Africa, the Agreement boosted garment exports to the United States by $62 \%$ in the first 14 years (IDC, 2016). When the MFA/ATC expired in 2004, the whole region suffered. In countries producing garments for export the effect was mitigated by the remaining Agreement with the US, though Madagascar and Swaziland suffered from suspensions for political reasons (Madagascar has since been reinstated), and Lesotho is currently under review. South Africa's textile and garment industry which was primarily focused on the domestic market was hit hardest, suffering from renewed competition from cheap Chinese imports despite reduced quotas. Jobs in the industry in South Africa more than halved, from 180,000 in 2002 to 80,000 in 2013 (IDC, 2016).

Currently, the garment industry in SADC serves primarily the South African rather than the US market, though Mozambique, Zambia and Malawi are gaining importance as destination markets. Four SADC countries - Swaziland, Lesotho, Mauritius and Madagascar - are among South Africa's top 10 suppliers of textiles and garments. As South African textile and garment companies struggle with high wages and strong unions, factories, both national and foreign, have been gradually relocating to other SADC countries. Fabric is sourced primarily from Asia, though a small part originates in South Africa.

Low availability of skilled labour in SADC relative to Asia and weak capacity to manage the entire supply chain are the main bottlenecks for textile industry development. Another obstacle to regional integration and development in the textiles sector is the $45 \%$ duty imposed on the import of textiles in all SADC countries (originating from the SADC Rules of Origin). Since South Africa (as well as many other SADC countries) does not produce most textile inputs, the duty places an undue burden on garment manufacturers and retailers.

Rules of origin are another obstacle to develop the sector (Box 1.2). Resolving the divergence between the Southern African Customs Union (SACU) and the rest of SADC in terms of the single versus double transformation rule for free trade is necessary. The double transformation means that a country should have the capacity to produce fabrics and garments, for such garments to enjoy preferential market access under regional trade terms. The rules of origin require companies to source both garments and textiles from within SADC to enjoy preferential export access to the SADC market. This measure, designed to protect the South African textile industry, hinders regional trade within SADC and weakens the region's international competitiveness in garment manufacturing. 


\section{The regional poultry chain is hampered by trade and infrastructure barriers}

The poultry industry produces and processes agricultural commodities through a quasi-industrial process of batch production of the rearing, processing, and distribution of poultry in fresh and frozen form (Ncube et al., 2016). The poultry market is approximately 1.8 billion dollars in South Africa and is expanding in SADC countries thanks to growing population and middle -class and development of urbanisation. The SADC region, as a whole, is in deficit and South Africa imports of poultry, mainly from Europe and South America, amounted to 270 million dollars in 2014. South Africa has increased duty tariffs on imports from EU countries to protect local producers since January 2015 for 5 years.

The four main stages of the value chain are: agriculture products (maize, soya and sunflower) and their transformation into animal feed; poultry breeding for day-old chicks; broiler growing; processing and distribution. A participant in the value chain can be vertically integrated and performing all the tasks in the chain or specialised in one segment of the value chain. Also, the countries in the region have different competitive advantages in the value chain. South Africa is the largest producer in absolute terms of both poultry and animal feed; it is also the largest importer and exporter of these products in the region. But Zambia is better placed to produce component crops of maize and soya.

The vertical integration of the largest firms in the sector, mainly from South Africa, is contributing to regional integration as they are expanding across the region. Trade flows of agricultural products are following the expansion of the poultry industry. In Zimbabwe, most imports of raw materials (i.e. maize, soya beans, and oil-cake) for animal feed come from Zambia. Because Zimbabwe has a ban on genetically modified maize, it does not import maize for animal feed production from South Africa which has the cheapest maize source because of its use of genetically modified seeds. As such, Zambia is the closest nongenetically modified maize source (Ncube et al., 2016).

The development of regional integration relies on more flows of agricultural products across member countries and cross-country investments made by large poultry companies. Removal of trade barriers (nontariff barriers in member countries such as import/export quotas and standards), a further development of the production of soybean meal in the region at a competitive price and better logistic and infrastructure environment would help the sector to grow further.

\section{Policies to foster regional trade integration}

\section{Strengthening the institutional framework to achieve SADC objectives}

SADC integration has been weakened by problems in implementing the agreements and protocols at the national level, as they often are not incorporated into domestic legislation. This is aggravated by lack of clarity in many of the SADC protocols on obligations and their implementation (Cronjé, 2015). SADC is based on inter-governmental coordination assisted by the SADC Secretariat, which has no supranational decision-making and implementing powers weakening further integration. Multiple memberships of most SADC countries in different regional communities such as SACU, or COMESA also create conflicts with rules and worsen the lack of compliance to agreements. The community needs a leadership, in particular, in the implementation of the agreements; South Africa is well-placed to play that role.

Giving more power to the SADC Secretariat to enforce the regional agenda and hold countries accountable for non-compliance would reinforce integration. In the absence of a regional parliament or body with legislative powers as in the East African Communities, the EU and ECOWAS, national parliaments should also be more involved in the adoption of regional policies. SADC would also benefit from having a central body or statistical agency and website that houses standardised and comparable economic data. 
Financing of SADC regional projects and policies remains a major challenge. An important part of the financing relies on international aid. Developing a permanent and stable internal source of funding for regional projects could facilitate the integration process. A defined percentage point added to VAT or customs duties in all countries, as in ECOWAS, devoted to a SADC budget could allow quickly to accelerate important regional projects.

\section{Reducing tariffs and non-tariff barriers would foster regional trade integration}

Estimates show that quantitative approximates of non-tariff measures affect negatively trade and can be particularly negative for SADC countries (Cadestin and Fall, 2017). Non-tariff barriers include licences, quotas and bans, price controls, competition policies, rules of origin and technical barriers to trade (technical norms). Poor infrastructure is another barrier. In addition, trade of SADC countries faces higher tariffs on external trade than many other regional trade groups (Figure 6 and UNCTAD, 2015). For example, for the EU, external tariffs are not detrimental to intra-trade. Low external tariffs are important for imported intermediate inputs. As most of the SADC countries have high external tariff rates, there is room to reduce these tariff rates (Figure 6). However, easing non-tariff measures both within the region and with countries outside the region has a great positive potential impact on trade for SADC countries.

Figure 6. Tariff rates are relatively high in SADC countries

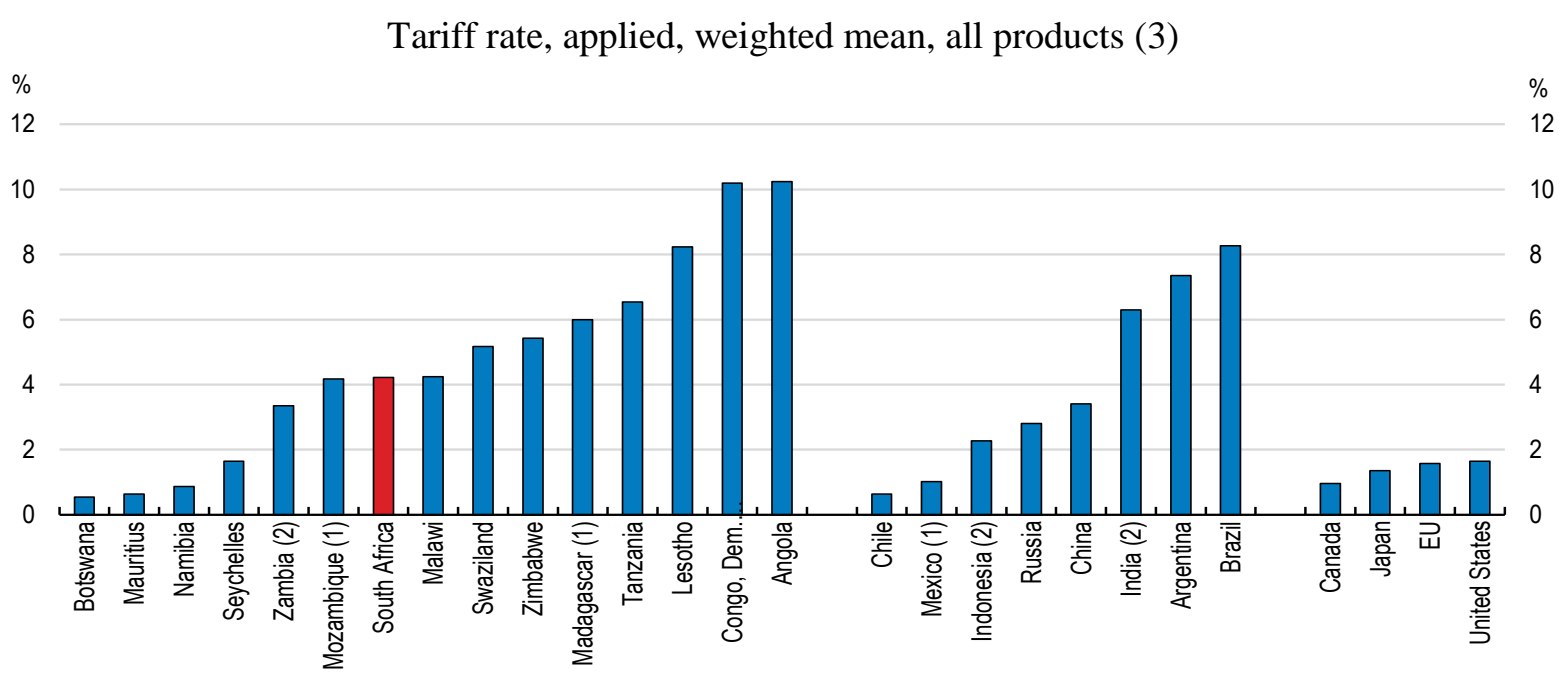

1. Numbers are for 2014.

2. Numbers are for 2013.

3. Weighted mean applied tariff is the average of effectively applied rates weighted by the product import shares corresponding to each partner country. Data are classified using the Harmonized System of trade at the six- or eight-digit level. Tariff line data were matched to Standard International Trade Classification (SITC) revision 3 codes to define commodity groups and import weights. To the extent possible, specific rates have been converted to their ad valorem equivalent rates and have been included in the calculation of weighted mean tariffs. When the effectively applied rate is unavailable, the most favoured nation rate is used instead.

Source: World Bank staff estimates using the World Integrated Trade Solution system.

High trade costs for SADC are due to a mix of poor infrastructure and non-tariff barriers. Using trade gravity estimations allows to measure the costs for trade of these different factors by applying a methodology proposed by Novy (2012) and Arvis et al. (2016) for developing countries. The results show that generally intra-regional trade costs are lower than extra-regional ones on average (Table 2). Trade costs are also higher in developing countries than in developed countries on average. In SADC intraregional average trade cost is higher than in South East-Asia. From SADC, the costliest regions to trade 


\section{ECO/WKP(2017)82}

with are Latin America, Eastern and Southern Africa, Europe and Central Asia, South Asia and South-East Asia (Table 2). This reveals that the high trade costs for SADC are due to a mix of poor infrastructure and non-tariff barriers.

The decomposition of trade costs performed by Arvis et al. (2016) confirms that in addition to traditional sources of trade costs, such as tariffs and transportation charges, a range of additional policy factors are affecting the pattern of trade in the region. In particular, transport connectivity and trade procedures are sources of trade costs, but they can be tackled by government policies. Also, regulatory and institutional features of countries that affect all firms are important sources of trade costs for developing countries.

Table 2. Region to region trade-weighted costs

\begin{tabular}{|c|c|c|c|c|c|c|c|c|c|c|c|}
\hline & EU28 & $\begin{array}{c}\text { Europe } \\
\& \\
\text { Central } \\
\text { Asia }\end{array}$ & $\begin{array}{c}\text { Eastern } \\
\& \\
\text { Southern } \\
\text { Africa }\end{array}$ & $\begin{array}{c}\text { Latin } \\
\text { America }\end{array}$ & $\begin{array}{c}\text { Middle } \\
\text { East \& } \\
\text { North } \\
\text { Africa }\end{array}$ & $\begin{array}{c}\text { North } \\
\text { America }\end{array}$ & Pacific & SADC & $\begin{array}{l}\text { South } \\
\text { Asia }\end{array}$ & $\begin{array}{c}\text { South- } \\
\text { East } \\
\text { Asia }\end{array}$ & $\begin{array}{c}\text { West } \\
\text { and } \\
\text { Central } \\
\text { Africa }\end{array}$ \\
\hline EU28 & 47 & & & & & & & & & & \\
\hline $\begin{array}{l}\text { Europe \& } \\
\text { Central Asia }\end{array}$ & 77 & 57 & & & & & & & & & \\
\hline $\begin{array}{l}\text { Eastern \& } \\
\text { Southern } \\
\text { Africa }\end{array}$ & 184 & 249 & 119 & & & & & & & & \\
\hline $\begin{array}{l}\text { Latin } \\
\text { America }\end{array}$ & 128 & 161 & 294 & 107 & & & & & & & \\
\hline $\begin{array}{l}\text { Middle East } \\
\text { \& North } \\
\text { Africa }\end{array}$ & 118 & 126 & 122 & 188 & 92 & & & & & & \\
\hline $\begin{array}{l}\text { North } \\
\text { America }\end{array}$ & 81 & 107 & 199 & 65 & 127 & 30 & & & & & \\
\hline Pacific & 115 & 142 & 413 & 186 & 144 & 102 & 55 & & & & \\
\hline SADC & 118 & 167 & 177 & 223 & 162 & 118 & 118 & 94 & & & \\
\hline South Asia & 126 & 145 & 148 & 199 & 112 & 112 & 129 & 167 & 99 & & \\
\hline $\begin{array}{l}\text { South-East } \\
\text { Asia }\end{array}$ & 104 & 120 & 191 & 138 & 140 & 77 & 92 & 167 & 123 & 66 & \\
\hline $\begin{array}{l}\text { West and } \\
\text { Central } \\
\text { Africa }\end{array}$ & 155 & 204 & 216 & 204 & 214 & 205 & 277 & 119 & 177 & 204 & 132 \\
\hline
\end{tabular}

Note: The table expresses the costs of trade from regions in row to regions in column. Figures show ad valorem equivalents of trade costs in percentages, calculated as in Arvis et al. (2016) using the trade cost measure proposed in Novy (2012). This is a comprehensive all-inclusive measure, not only tariffs and transport costs but also direct and indirect costs associated with differences in languages, currencies as well as cumbersome import or export procedures. The weights are based on total trade.

Source: OECD calculations based on ESCAP-World Bank Trade Cost Database.

The trade facilitation index confirms that more can be done in the SADC region to boost trade by simplifying trade procedures and improving infrastructure. Performance across SADC countries is widely below EU or the OECD average (Figure 7). Mauritius and SACU countries have a more friendly trade environment than the rest of SADC. Many SADC countries have a trade enabling environment below the MERCOSUR average country. The following discusses in more detail the nature of some key subcomponents of the index. 


\section{Figure 7. Trade facilitation index}

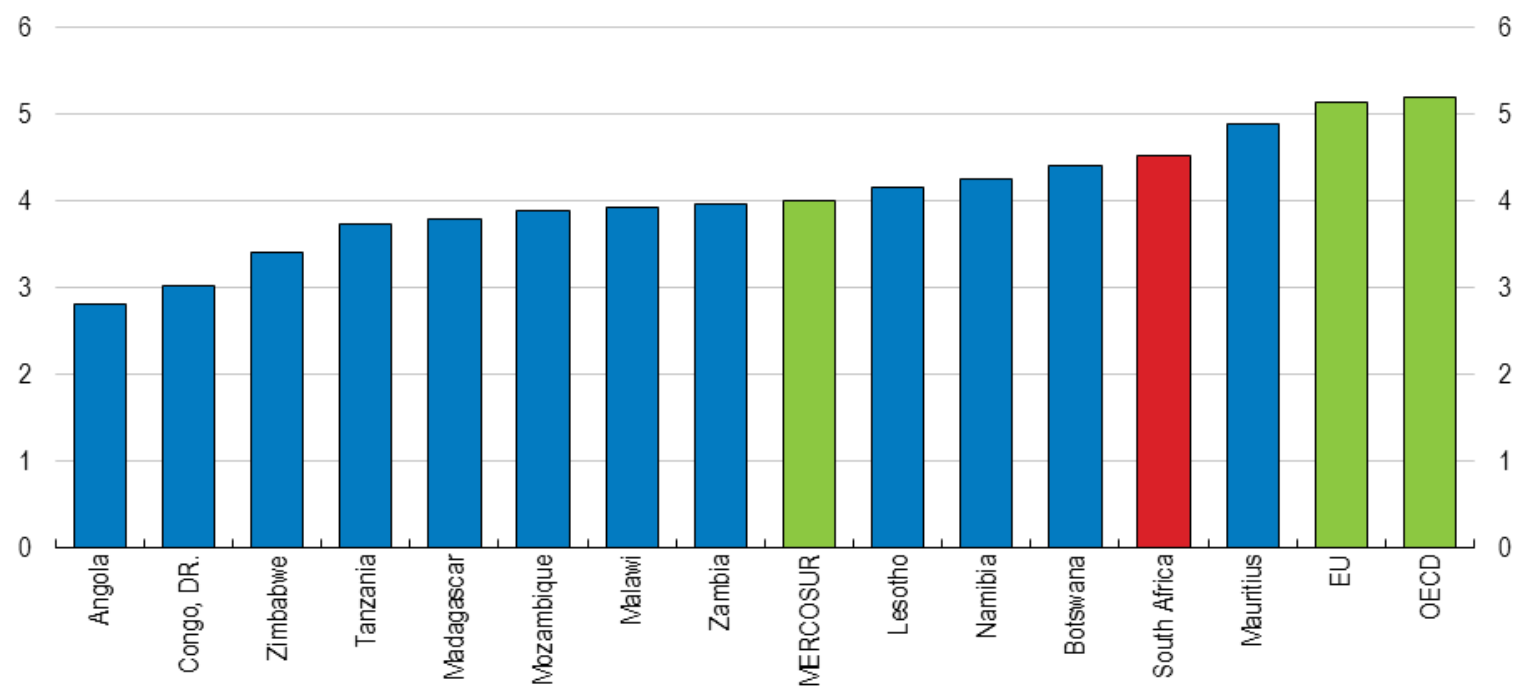

Note: The Enabling Trade Index assesses the extent to which economies have in place institutions, policies, infrastructure and services facilitating the free flow of goods over borders and to their destination. Score 1-7 (best).

Source: World Economic Forum, Global Enabling Trade Report.

\section{There is room to improve customs policies}

Customs procedures are complex within SADC compared to the OECD average (Figure 8). The multiple memberships of SADC countries in different free trade areas increase the difficulty for customs officers to establish the precise preferential tariffs applying to each product. Angola has the most burdensome customs procedures, while Mauritius is the most performant. South Africa, the regional leader and source of most regional trade, ranks fourth. Transporters complain that borders do not operate on a 24hour basis, of electrical and technical shutdowns in the border systems, and incompatibility of customs systems between countries (Vilakazi and Paleo, 2017a, UNCTAD, 2015).

Customs strategies often focus on revenue mobilisation at the expense of trade facilitation. Some SADC members have even raised import tariffs on products originating from the region to raise revenue, in flagrant violation of their regional tariff liberalisation commitments (Shayanowako, 2015).

As recognised by the strategic plan of the SADC Sub-Committee on Customs Co-operation, there is a need to enhance skills of customs officials in areas such as clearance controls and risk management, managing trader compliance and applying measures to enforce compliance (SADC, 2011b). In terms of information and communication technologies, scaling up the availability and use of such technologies and better exploiting them would improve automatic data processing and interconnectivity between neighbouring border agencies. Given the skills shortage and compliance difficulties, SADC countries should invest into simple and robust information and communication technologies and infrastructure.

Moreover, the incidence of corruption at customs remains high in the region (Shayanowako, 2015). Introducing a computerized one-stop border control point between SADC members can improve coordination between countries and help fight corruption and unnecessary red tape. Finally, accelerating the adoption by all SADC countries of legislation facilitating interagency co-operation, advance rulings and post-clearance audit would facilitate intra-regional trade. As recognised in the SADC assessment, considerable gaps remain in SADC countries in terms of compliance and implementation of commonly agreed policies. For instance, only one country was applying the Common tariff nomenclature template, three countries the customs model act and four countries have one stop border posts (SADC, 2011c). 
Figure 8. Burden of customs procedures

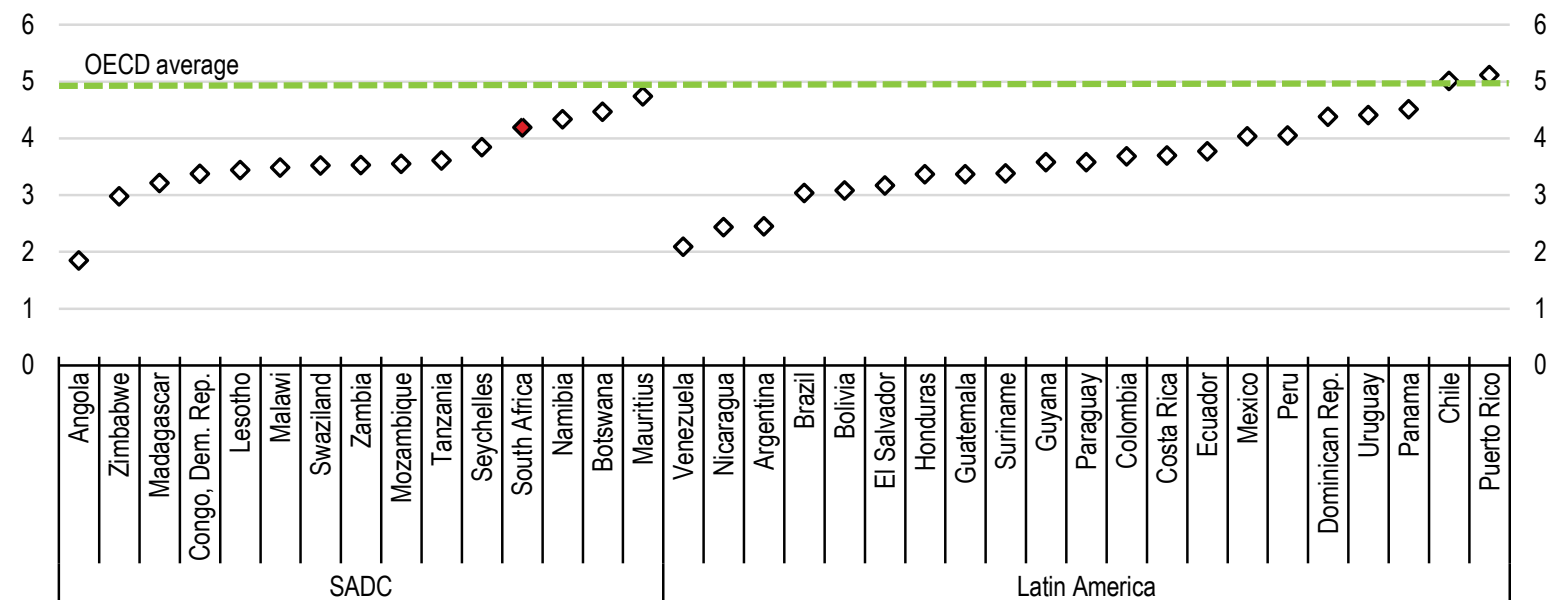

Note: Data are standardised scores. 0 represent the OECD average and 1 denotes one standard deviation in the sample of OECD countries; scores above the zero line mean better performance than the OECD average by one, two or three standard deviation.

Source: World Economic Forum, Global Competitiveness Report.

\section{SADC rules of origin are complex}

Rules of origin can become a non-tariff barrier. In a free trade area, rules of origin are set to prevent tax avoidance by exploiting differences in tariffs among member countries. Rules of origin are defined to guarantee that substantial transformations happen on imported goods in the importing country of the FTA before the product is traded with another member of the same FTA. Rules of origin are important mostly for manufactured goods. However, as production processes are more and more globalised with global outsourcing and value chains, defining rules of origin not harmful to the competitiveness of industries is difficult.

Different methods are applied across countries and agreements to determine the part of transformation made in importing countries and whether this is substantial (Abreu, 2013; Sandrey, 2015). SADC has adopted rather complex rules of origin, defined product by product and requiring double stage transformation. A simpler alternative would be the across-the-board approach adopted by COMESA (Box 2).

In SADC, the rules of origin were mainly designed to protect existing industries from increased intraregional competition, in particular the textile and clothing industry in South Africa (Brenton et al. 2005). Rather than facilitating development through trade, the complex and restrictive input-sourcing requirements of the SADC rules of origin have a negative impact on trade and attractiveness for industrial investment. In the absence of reform to simplify rules of origin, the manual by the SADC Secretariat for rules of origin (SADC, 2003) should be applied by all member countries to facilitate the application of existing rules of origin.

\section{Broadening the scope of the trade agreements could boost regional trade and integration}

\section{Liberalisation of trade in services could tackle skills shortages and increase business competitiveness}

SADC members have adopted a Protocol on Trade in Services in August 2012 aiming to establish an integrated regional market for services (SADC, 2012). The Protocol defines general obligations for 
member states on the treatment of services and service suppliers from other member states and Third Parties. However, there is no cut-off date for service liberalisation. The initial aim was to conclude the negotiations to remove barriers to the free movement of services in three years. The Protocol was amended in August 2016 as the negotiations dragged on. Six priority sectors (communication, construction, energyrelated, financial services, and tourism and transport services) were initially defined for the first round of negotiations. The objective is to open-up markets for trade and investment in the sectors within the region.

Service trade liberalisation within the region would have a positive impact on economic activity and well-being in the different countries. Services are an important part of GDP. In South Africa, the service sector already represents $70 \%$ of GDP and $16 \%$ of its exports. Services exports are also more than $30 \%$ of total exports already in Mauritius, the Seychelles, Mozambique and Tanzania (Figure 9). Restrictions on the provision of some services are high in South Africa compared to other countries (Figure 10). Service trade liberalisation would allow consumers and businesses to have access to better services at lower prices through competition effects. For instance, Dihel and Goswani (2016) find that opening of professional services (accounting and engineering services) has had a positive impact on labour productivity in several African countries. They also find that service trade increases GVC participation but access to quality services locally is challenging.

Figure 9. Service export is sizeable in many SADC countries
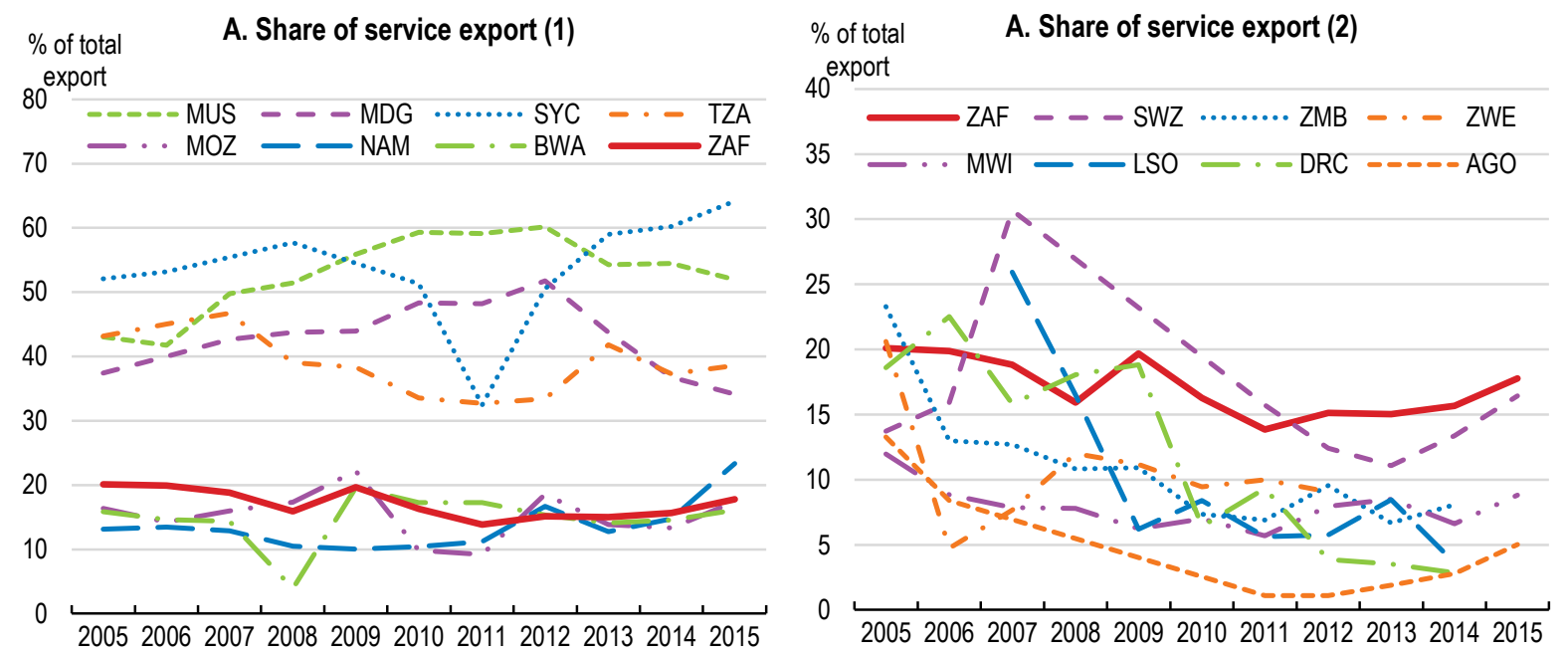

Source: International Trade Centre.

Other estimates of potential gains in service liberalisation also indicate positive macroeconomic impacts. In Dee et al. (2011), a 50\% reduction of barriers to investment in services affecting foreign investors globally would increase South African GDP by $0.2 \%$ in the long run. A recent estimation by Jensen and Sandrey (2016), using the same methodology with new data and a new version of the Global Trade Analysis Project model, show that the GDP would be $0.4 \%$ higher. Moreover, when considering a $50 \%$ reduction of barriers to investment in services affecting both national and foreign investors, South Africa's real GDP would rise by 3.2\%. As pointed by Dee and Findlay (2008), countries with high barriers to trade for foreigners tend to have high barriers to trade domestically. Therefore, implementing the SADC protocol on service liberalisation would be beneficial to all countries.

A directive for the implementation of the Protocol on services would clarify the overlapping of protocols and set the list of sectors not covered by the Protocol on services. A directive negotiated between member countries under the leadership of the SADC Secretariat could establish a timeline and guidelines for the services liberalisation and provide derogations where needed. 
Explicitly developing the concept of "community acquis" in the protocols would simplify the elaboration and the complementarity of different generations of protocols. For instance, the European Union directive on services defined the implementation strategy of the service liberalisation and provides an example of progressive liberalisation (EU, 2006). A legally binding directive to implement the agreement should cover simplification of administrative requirements and procedures and enhance transparency; set minimum standards; develop codes of good conduct to ensure quality; and, recognise each other's systems, practices and requirements (Cronjé, 2014). It should not lower existing standards and norms on services.

Figure 10. Restrictions on foreign provision of some services are high relative to other countries

OECD Services Trade Restrictiveness Index ${ }^{1}$

\section{A. Logistics cargo-handling}
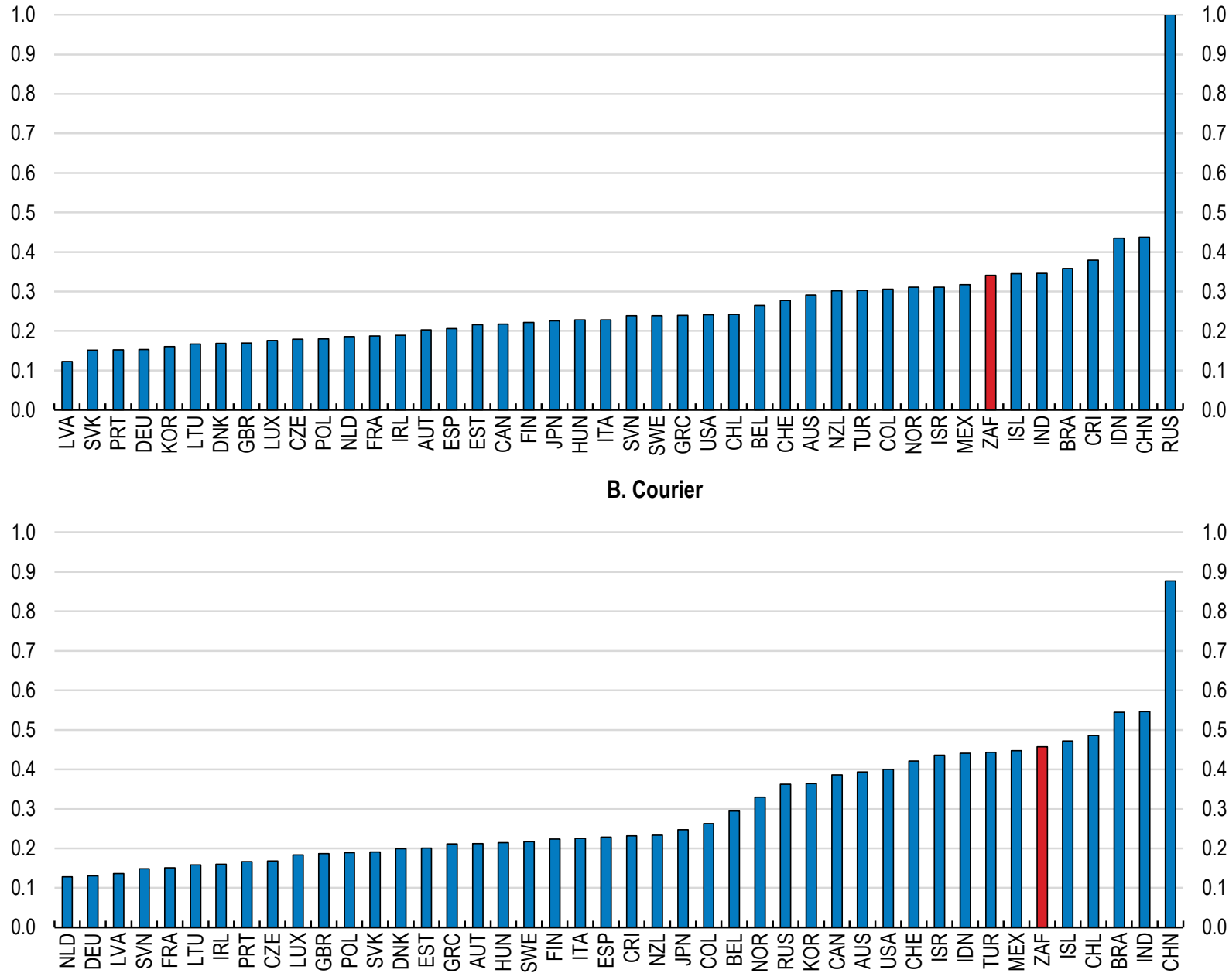

1. STRI indices take the value from 0 to 1 , where 0 is completely open and 1 is completely closed.

Source: OECD Services Trade Restrictiveness Index Database.

A broadening of the Protocol on services toward services not covered by already existing protocols would deepen the scope of trade services integration. Given skill shortages in the region in many domains, such broadening of services covered has an important potential economic impact. For instance, business services such as management consultancy, certification and testing, facilities management and services provided both to businesses and to consumers, such as legal or fiscal advice, or architects services have the 
potential for market integration. One of the main difficulties in trade services liberalisation in the region is the limitations of the free circulation and movement of people between member countries. It is a major impediment to service liberalisation as many of those activities may require proximity of providers and recipients, or travel by the recipient or the provider. Therefore, the service liberalisation should move with a clear understanding and rules for freedom of movement and settlement of professionals concerned by service liberalisation.

Also, services trade liberalisation should respect service regulations. For example, in the case of professional services, it is necessary to ease restrictions on the entry of foreign professionals, establishment of foreign companies, and cross-border supply of services without lowering standards. Specific changes could include minimising the restrictions on the kinds of businesses permitted, developing a transparent and consistent framework for accepting foreign-qualified professionals, and relaxing barriers to foreigners participating in partnerships (Dihel and Goswani (2016). Easing discriminatory procurement regulations and reforming immigration laws could complement these steps.

More generally, there is a need for coherent regulatory policies across member states in many regulated services to permit any creation of an integrated market for different services sectors. As domestic regulators determine the conditions of access to and operations in the market, integration of services sectors of different countries requires at least convergence of the national regulatory frameworks and regional regulatory co-operation.

Finally, deeper service integration cannot happen if many network services across member countries remain closed with monopolistic state owned enterprises. A progressive opening of some of these network services would boost services integration. The energy sector, where some interconnection of networks and transactions within the region are already taking place, is a good candidate to start with. It would also help reduce the electricity deficit in some countries. However, that would require important regulatory reforms (see Cronjé, 2014 and OECD, 2015).

\section{The Tripartite free trade area could reduce the complexity created by multiple membership}

The adopted tripartite free trade area (TFTA) (see Box 1) is currently incomplete and not applicable as it stands (Erasmus, 2015). There is no legally binding instrument and most of the annexes complementing the agreement are only principles. There is also no agreement on tariffs and rules of origin. The current TFTA has also not eliminated the overlap with existing free trade agreements. The TFTA should not try to maintain the coexistence of the three sets of rules. Furthermore, the extension of tariff offers between those Member States not part of the same FTAs will only increase the complexity of trade within the TFTA area. Another example is the maintaining of different rules of origin within the TFTA (see Box 2). For a real integrated regional market, it is necessary to define a common set of rules for each pending issue (tariffs, rules of origin) and then agree on the convergence path for their application.

\section{Box 2. The difficulty of defining common rules within the FTA: the case of rules of origin}

Rules of origin are among the open issues to conclude the Tripartite free trade area signed in June 2015. Article 12 and Annex 4 of the TFTA Agreement set out the criteria and conditions for goods to qualify for preferential rules of origin based on a product list. However, at the time of the launch, only about $25 \%$ of the product list had been negotiated and agreed. The parties agreed to pursue the negotiations and reach an agreement within twelve months. These negotiations are ongoing and the SADC secretariat announced in October 2016 that an agreement has been reached between country experts and is under review by countries. The discussion below illustrates the difficulty and the complexity of setting common rules of origin between the three regional Agreements.

COMESA and EAC have a different approach of the rules of origin compared to SADC. The easiest part of the negotiations is for non- manufactured goods for which the three agreements have common rules. The difficulty 


\begin{abstract}
is for manufactured goods incorporating imported inputs. The produced good is deemed originating from a member country only if "substantial transformation" happened in the country in the production process. The current regional agreements differ in their approach of the concept of "substantial transformation". For COMESA and the East African Community, which have similar rules of origin, a percentage of local content determines the origin: $35 \%$ of value added has to come locally or $60 \%$ of ex-factory costs of imported materials of the cost and freight (c.i.f.) value. SADC rules of origin are more complex and defined product by product. The productspecific rules use a variety of methods for determining eligibility, but tend to contain high value-added requirements and low levels of import contents. A review in 2004 resulted in the relaxation of some productspecific rules, but rules for most textiles and clothing items are still based on double-stage transformation.
\end{abstract}

The aim of the Tripartite free trade area is to simplify and boost trade among members which can only be reached with a single set of flexible rules of origin. The concerns with the rules of origin is exacerbated by the heterogeneity of tax systems between member countries (see section on tax competition) and the differences in tariffs applied to non-members.

Also, rules of origin are used as a protectionist measure to shelter domestic producers of 'sensitive products' from competition (Erasmus, 2015). At the core of this problem lies a belief that rules of origin can promote industrialisation, particularly the development of upstream-downstream production networks, by making local or regional content a necessary condition for enjoying trade preferences.

Source: Erasmus, G. (2015), "The Tripartite Free Trade Agreement: Results of Phase One of the Negotiations", Tralac Working Paper US15WP04/2015 and Annex 4 of the Tripartite Free Trade Agreement (https://www.tralac.org/images/Resources/Tripartite_FTA/TFTA\%20Annex\%2004\%20Rules\%20of\%20Origin\%20Re vised\%20Dec\%202010.pdf)

\title{
The EU Economic Partnership Agreement with some SADC countries increases regional fragmentation
}

Economic Partnership Agreements (EPA) were introduced by the Cotonou Agreement signed in 2000 marking a major change in the trade relationship between the EU and developing countries (Box 3). These replaced the non-reciprocal trade preferences that existed under the previous agreements by a reciprocal trade arrangement that offers duty free access for EU exports in the developing country member markets. The agreements were to enter in effect in 2008, and a transition period from 2008 to 2020 was planned for signing of EPAs and implementation of reciprocity. The main justification of the EPAs is that it is "WTO compliant".

The negotiations and agreement on EPAs have proved difficult as the European partnership agreement exposes African economies to competition from EU products, especially in agriculture, and can lower customs revenues. So far, agreements have been concluded with five SADC/SACU countries (Botswana, Lesotho, Namibia, South Africa and Swaziland) and Mozambique in 2014. The agreement with SACU countries is being provisionally applied as of 10 October 2016 pending ratification by all EU Member States. Mozambique is expected to ratify in 2017.

The negotiations were accelerated by the threat of expiring benefits from previous agreement with the EU in October 2016. At the expiration, trade with the EU would be under the EU's Generalised System of Preferences which excludes, for example, beef and table grapes, which would hurt in particular Namibia. Also, South Africa had already a bilateral Trade, Development and Co-operation Agreement (TDCA) concluded in 2000 which is close to the EPA, which expires with the application of EPA.

However some safeguards have been agreed. Export taxes are allowed for some exports for a period of 12 years at predetermined rates. On agricultural exports, flexible activation clauses are included permitting to protect, when deemed necessary, local producers from large inflows of EU goods and the EU has agreed to eliminate subsidies on several exported goods. For instance, Namibia secured a framework for the exports of fish products from its Exclusive Economic Zone. Finally, negotiation on trade in services will continue. 


\section{Box 3. The Origin of the Economic Partnership Agreement}

The first trade partnership agreement between the European Union and Sub-Saharan Africa countries was the Yaoundé Convention I concluded in 1962, which granted duty-free access of specified goods from 17 SubSaharan countries and Madagascar. The agreement was renewed by the Yaoundé Convention II in 1969, and replaced by the Lomé Convention in 1975 between 9 European Community member states and 46 developing countries from Africa, the Caribbean and the Pacific (ACP countries). It provided duty-free access to the European market for agricultural and mineral exports, and preferential quotas for products in competition with European agriculture such as sugar and beef. The Lomé Convention was renegotiated three times (Lomé II, III and IV) over a 25 year period and expanded to 70 countries. The ACP countries received about ECU 30 billion of aid and investment in addition to the trade preferences. These were replaced by the Cotonou agreement between the then $15 \mathrm{EU}$ member countries and 77 ACP countries in 2000 to reduce complexity and make the agreement compatible with international trade rules (GATT and WTO). The Cotonou agreement gave birth to the Economic Partnership Agreements.

Source: Turkson, F. E. (2012), "Trade Agreements and Bilateral Trade in Sub-Saharan Africa: Estimating the Trade Effects of the EU-ACP PTA and RTAs", Centre for Research in Economic Development and International Trade, Working Paper 12/07, University of Nottingham

Benefits from the EPA trade agreements may be greater for the EU countries than for the SADC partners. The EU is one of the largest trading partners of SADC, in particular of South Africa, in imports and exports (Figures 2 and 11), and imports from the EU are likely to increase after the most recent tariff reductions or elimination in the partnership agreement (see poultry section). Exports of SADC countries to the EU may increase by less due to weak competitiveness and undiversified production structure (Mevel et al. 2015 and Fundira, 2017).

The agreement between a fraction of SADC countries and the EU will also increase the fragmentation of SADC trade agreements, which can hamper deeper integration. To avoid further fragmentation of trade agreements within SADC, members should agree to negotiate with external partners only under the SADC umbrella based on a binding and robust framework which guarantees that all countries' concerns are taken into account. The SADC Secretariat should also be reinforced to increase its capacity to represent member countries. 
Figure 11. Trade between SADC and the European Union

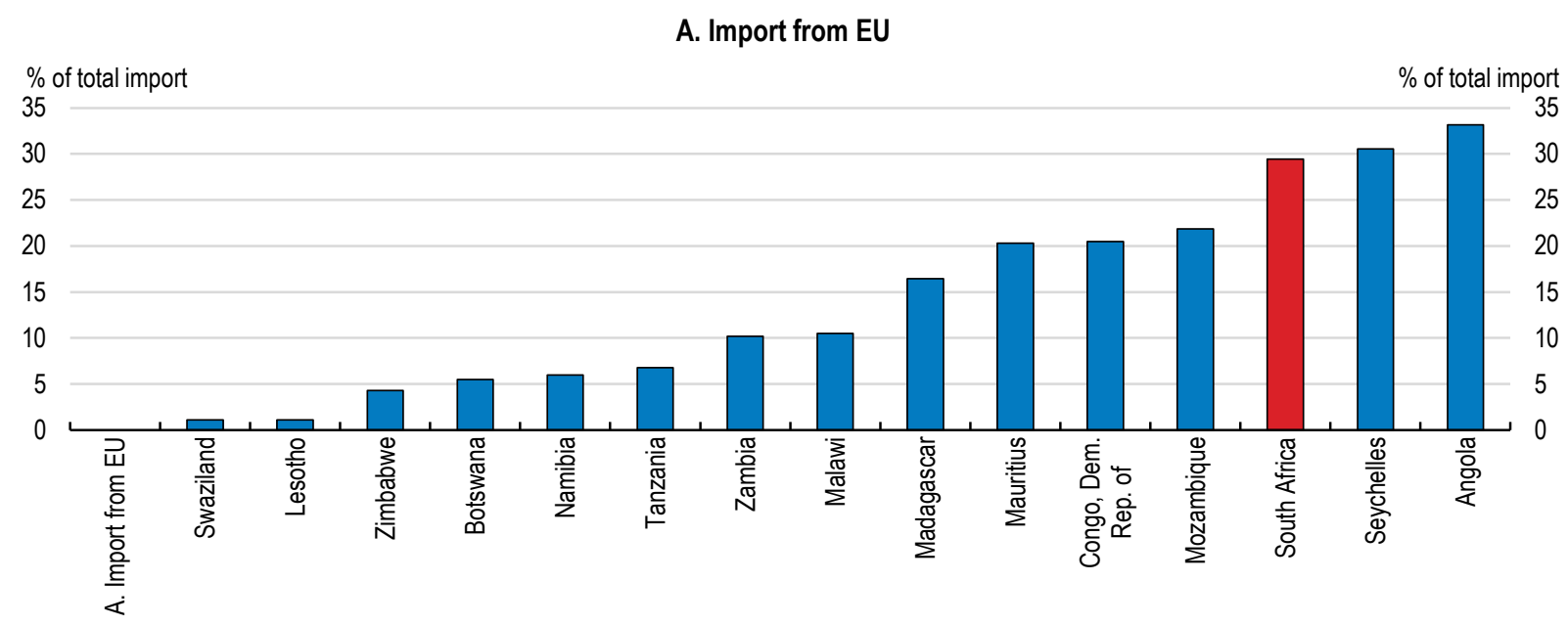

B. Export from EU

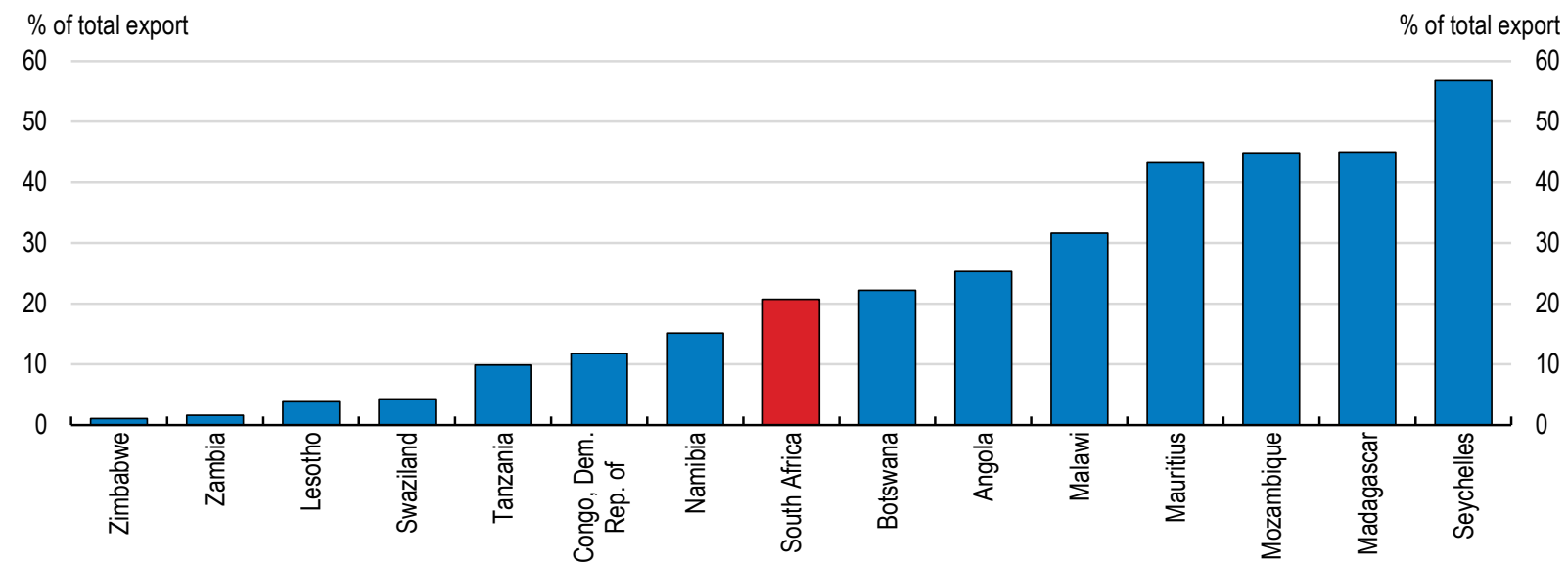

Source: IMF, Direction of Trade Statistics database.

\section{Reforming the Southern African Customs Union (SACU) to foster regional integration}

The SACU arrangement has many internal difficulties with knock-on effects on SADC regional integration. Intra-union customs border posts have not been eliminated because revenue sharing is partially based on intra-SACU trade, thus reducing benefits of trade facilitation. Second, there is a substantial income transfer from South Africa to the other members. SACU revenues now represent the main source of government revenues for SACU members, except South Africa (Figure 12). This has created perverse incentives across the other SACU members to resist any changes to tariffs and extension of the SACU union to new members (Flatters and Stern, 2006). Moreover, the difficulty of reforming the SACU arrangement is delaying the evolution of the SADC free trade area toward a customs union as intended. Reforming the SACU sharing formula and mechanism of tariff settings would ease the negotiations toward SADC customs policy harmonisation. 
Figure 12. Contribution of SACU revenue to member countries' government budget, 2014/15

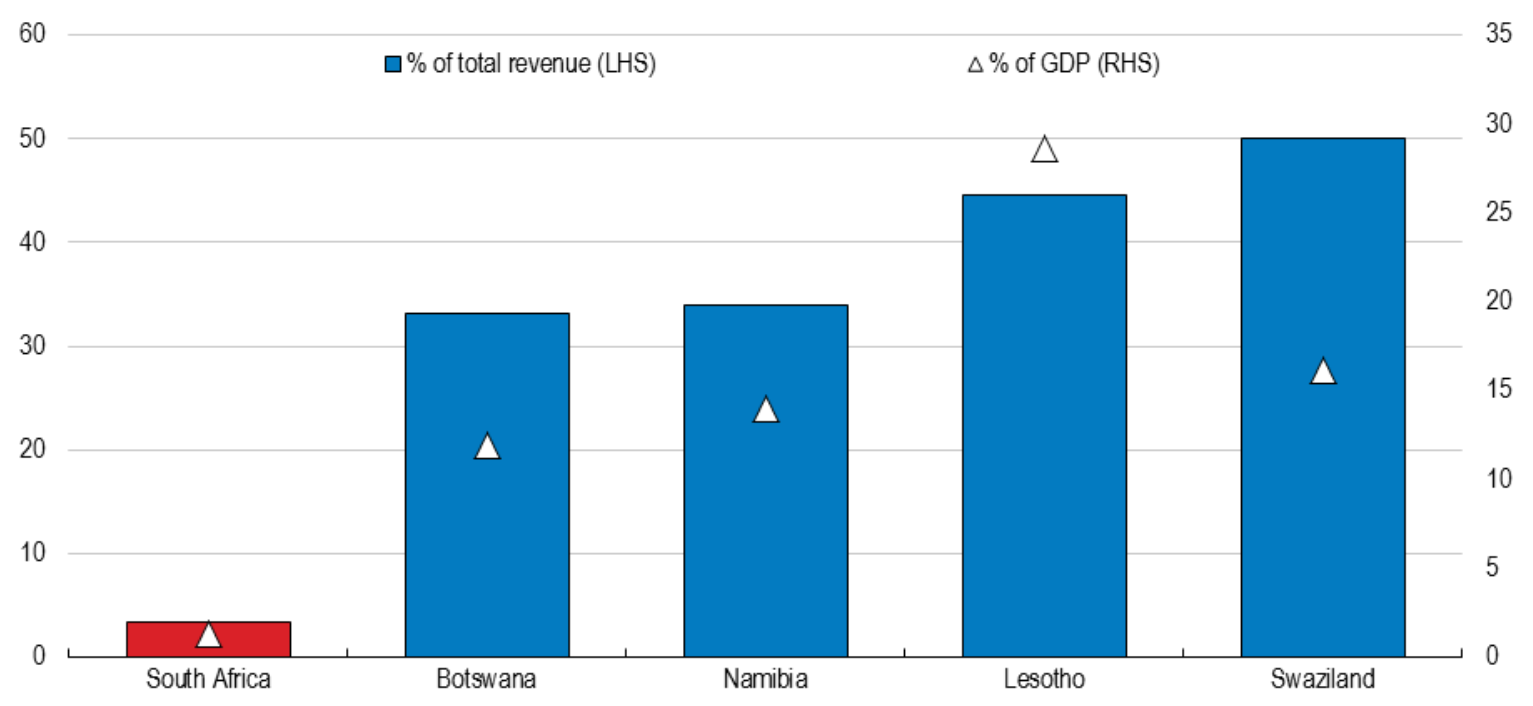

Source: SACU, Annual Report 2015.

\section{Reforming the enabling environment to strengthen regional integration}

\section{Favouring the development of industries at the regional level}

Regional industrialisation has become a top priority in the revised Regional Indicative Strategic Development Plan 2015-2020 of the SADC, which is the main SADC policy document. Member states have also adopted the SADC Industrialisation Strategy and Roadmap 2015-2063 in 2015. The Strategy has three pillars: industrialisation, trade and regional integration and geography (SADC, 2015a). The industrialisation strategy rests on increasing productivity through manufacturing including agro-processing and minerals.

The level of industrialisation is low across SADC countries (Figure 13, Panel A). Even in South Africa, which has the most sophisticated industry in the region, the share of manufacturing in GDP is low. SADC countries have failed so far to increase value added in sectors, such as minerals and raw materials where they have some comparative advantages. The justification of SADC regional industrial policy rests on the common features of SADC countries in terms of a small market, lack of competitiveness and needs to co-operate in tackling structural barriers (Figure 13, Panel B). 
Figure 13. Degree of industrialisation and competitiveness of SADC countries

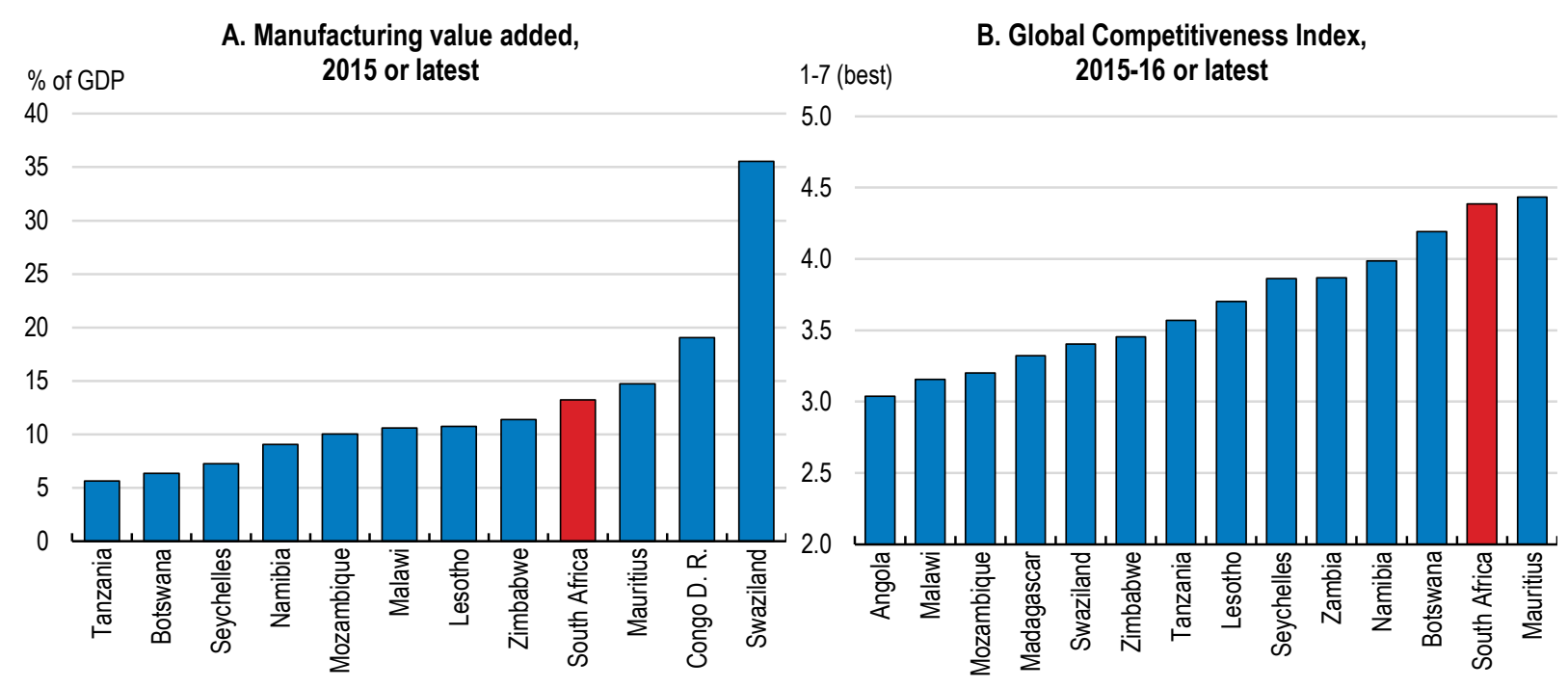

Source: World Bank; World Economic Forum, The Global Competitiveness Index.

The main barriers to the development of industry in the region are related to the enabling environment. Lack of proper infrastructure and institutions, skill shortages, complex regulations are common across SADC countries, and constitute bottlenecks to the development of industry in any sector. For example, in Mozambique, technical and higher-level skills are lacking, and firms see lack of employee skills as a serious constraint to growth (Newman et al., 2016). Skill shortage is also a major constraint in South Africa (see Lewis et Gasealahwe, 2017 and OECD, 2017b). Regulatory barriers, monopolistic behaviours and dominant state own enterprises are common across countries. These factors reduce competition and increase the average cost of doing business, making the region less competitive compared to Asian economies. Infrastructure is also a binding constraint. Delays at borders cost around USD 400 per truck per day (Vilakazi and Paleo, 2017a); that represents around USD 13 per tonne, which can be as high as one quarter of the rate charged for the route (Lusaka and Johannesburg or Lilongwe to Maputo and Beira). As put by Newman et al. (2016), for industrialisation in African countries, including SADC, setting the environment right, starting with closing the infrastructure gap, is the first priority (see section below).

As already pointed out, institutional reforms at the regional level to facilitate trade logistics should be speeded up. The journey from Kolwezi (D.R. of Congo) to Johannesburg (South Africa), of about $3000 \mathrm{~km}$, takes fifteen to twenty days, $70 \%$ of which is spent as downtime at border crossings (Newman et al. (2016). All measures facilitating trade and exports (one-stop border facilities, efficient customs, logistics, etc.) would reduce costs of doing business.

Third, special economic zones should be better linked to the rest of the economy to create cluster effects. The experience of special economic and processing zones is not positive in Africa (Farole, 2011). Apart from Mauritius, investment and exports are low, and job creation has been limited. Most have relied on tax incentives and holidays, which are insufficient if the business environment remains unfavourable. The most commonly used tax incentives across the region are alternative minimum corporate income tax rates and preferential sector benefits in the tourism, agriculture and manufacturing sectors (Table 3). In addition to reduced income tax rates, companies also benefit from sizeable capital allowances and other investments and expenditure deductions, and exemptions from import duty, VAT, withholding and local taxes. Many tax incentives also remain at the discretion of government ministries with some companies 
with a large enough investment being able to strike individual agreements with the government with generous fiscal concessions.

To make successful special economic zones, more focus should be put on the infrastructure quality, business environment and linkages with the rest of the economy to create agglomeration effects. In SADC, access to regular electricity, capacity to import intermediate inputs without additional duties, functioning road transports, easy customs procedures and supply of skilled workers would make the zones, like the rest of the economies, more successful. In South Africa, a better location of special economic zones closer to agglomerations could increase their effectiveness.

Finally, access to finance is a major issue in many SADC countries. Apart from attracting foreign direct investment, industrial development requires the participation of local producers to the value chain. There is a need to set up financing schemes that help local entities and SMEs to have better access to finance for the upgrading of their technologies (see Lewis et al., 2017).

Table 3. Investment incentives across SADC countries

\begin{tabular}{|c|c|c|c|c|}
\hline & Incentives & Sectors/Target & Criteria & Duration \\
\hline Angola & $\begin{array}{l}\text { Exemption or rate reduction for } \\
\text { investment }\end{array}$ & All sectors & $1 \mathrm{~m}$ USD & $6-10$ years \\
\hline DRC & Exemptions/reductions for investment & $\begin{array}{l}\text { Excl: mining, Finance and } \\
\text { trade }\end{array}$ & 200K USD & $\begin{array}{l}\text { Project } \\
\text { duration }\end{array}$ \\
\hline \multirow[t]{6}{*}{ Madagascar } & Exemptions & microfinance & & 5 years \\
\hline & Preferential sector treatment & $\begin{array}{l}\text { Industrial and service } \\
\text { exporters }\end{array}$ & & $2-5$ years \\
\hline & $\begin{array}{l}\text { Reduction for investment ( } 50 \% \text { on } \\
\text { investment during the related tax year) }\end{array}$ & $\begin{array}{l}\text { Renewables, tourism, } \\
\text { construction, and } \\
\text { transformation }\end{array}$ & & $\begin{array}{l}\text { Project } \\
\text { duration }\end{array}$ \\
\hline & Preferential sector treatment (investment) & Mining investment & 50m USD & $\begin{array}{l}\text { Project } \\
\text { duration }\end{array}$ \\
\hline & custom and import duty exemptions & Petroleum exploration & & $\begin{array}{l}\text { Project } \\
\text { duration }\end{array}$ \\
\hline & Exemptions for investment & All sectors & & 4 years \\
\hline \multirow[t]{3}{*}{ Malawi } & Export allowances: $25 \%$ & Manufacturing & & $\begin{array}{l}\text { Project } \\
\text { duration }\end{array}$ \\
\hline & $\begin{array}{l}\text { Investment allowance of } 100 \% \text { for new } \\
\text { buildings and } 40 \% \text { for used }\end{array}$ & Manufacturing & & $\begin{array}{l}\text { Project } \\
\text { duration }\end{array}$ \\
\hline & Expenditure allowances (100\%) & Mining, Agriculture & & \\
\hline Mauritius & Tax-free economic zones & Exporters in Freeport zone & No minimum & $\begin{array}{l}\text { Project } \\
\text { duration }\end{array}$ \\
\hline \multirow[t]{3}{*}{ Mozambique } & $\begin{array}{l}\text { Investment allowances of } 5 \% \text { to } 10 \% \text {, up } \\
\text { to the total amount of CIT liability. }\end{array}$ & $\begin{array}{l}\text { For productive assets in all } \\
\text { sectors }\end{array}$ & & 5 \\
\hline & Expenditure deductions of $50-120 \%$ & $\begin{array}{l}\text { Exploration/mining } \\
\text { incentives }\end{array}$ & & 5 \\
\hline & Customs and VAT exemptions & $\begin{array}{l}\text { Capita equipment in all } \\
\text { sectors }\end{array}$ & & $\begin{array}{l}\text { Project } \\
\text { duration }\end{array}$ \\
\hline \multirow[t]{2}{*}{ Namibia } & $\begin{array}{l}\text { Various allowances (building, employee, } \\
\text { export, transport }\end{array}$ & $\begin{array}{l}\text { All sectors, with additional } \\
\text { benefits for manufacturing }\end{array}$ & $\begin{array}{l}\text { Exports } \\
\text { outside } \\
\text { SACU }\end{array}$ & \\
\hline & Tax-free economic zones & $\begin{array}{l}\text { Manufacturing and } \\
\text { exporters in EPZ }\end{array}$ & & Unlimited \\
\hline Seychelles & Tax-free economic zones & Offshoring & & Unlimited \\
\hline South Africa & $\begin{array}{l}\text { Numerous incentives aimed at } \\
\text { encouraging investment, } R \& D \text { and } \\
\text { infrastructure development }\end{array}$ & $\begin{array}{l}\text { All sectors, prioritising } \\
\text { manufacturing }\end{array}$ & depends & varied \\
\hline Tanzania & Reduced corporate tax rate of $25 \%$ & newly listings on DSE & $\begin{array}{l}30 \% \text { of } \\
\text { shares } \\
\text { public }\end{array}$ & 3 years \\
\hline
\end{tabular}


Table 3. Investment incentives across SADC countries contd

\begin{tabular}{|c|c|c|c|c|}
\hline & Capital deductions:5- $100 \%$ & $\begin{array}{l}\text { Agriculture, manufacturing, mining } \\
\text { and tourism }\end{array}$ & & $\begin{array}{l}\text { Project } \\
\text { duration }\end{array}$ \\
\hline & $\begin{array}{l}\text { Tax-free export and } \\
\text { economic zone }\end{array}$ & exporters & $\begin{array}{l}\text { Export min } 80 \% \\
\text { output }\end{array}$ & 10 years \\
\hline Zambia & Tax holidays & $\begin{array}{l}\text { Agriculture, manufacturing and } \\
\text { approved SEZs }\end{array}$ & $500 \mathrm{~K}$ USD & 5 years \\
\hline \multirow[t]{3}{*}{ Zimbabwe } & Reduced tax rate & Mining & special lease & $\begin{array}{l}\text { Project } \\
\text { duration }\end{array}$ \\
\hline & Reduced tax rate & Manufacturing & $\begin{array}{l}\text { exporting } \min 30 \% \\
\text { output }\end{array}$ & $\begin{array}{l}\text { Project } \\
\text { duration }\end{array}$ \\
\hline & Tax holidays & Tourism and industrial SEZs & & 5 years \\
\hline
\end{tabular}

Source: OECD compilation.

\section{Upgrading regional infrastructure quality and availability}

The SADC Regional Infrastructure Development Master Plan recognises that reducing transaction costs for industry and trade is essential to enhance regional integration. Infrastructure plays a major role in growth in Africa and contributed more than other structural policies to per capita economic growth between 1990 and 2005 (Calderón et al., 2008). However, the deterioration in the quantity and quality of energy infrastructure over the same period retarded growth. In Southern Africa, it is estimated to have cost 20 basis points from per capita growth (Foster et al. 2010). Poor infrastructure has been estimated to depress firm productivity by about $40 \%$ (Escribano et al., 2010). Therefore, making services related to infrastructure (transports, communications, ICT, energy and water supply) available, affordable and reliable is indispensable for further regional integration and economic growth.

Despite important efforts in the last decade, infrastructure gaps remain important within SADC. Quantity and quality of transport infrastructure is low. Only South Africa is close to the OECD average on the index of transport infrastructure and most SADC countries have poor transport infrastructure (Figure 14). Even in South Africa there is ample room to improve the quantity and quality of infrastructure, and lower costs (OECD, 2015). The energy sector has the largest unmet needs across the region (Foster et al., 2010). Furthermore, Byiers and Vanheukelom (2014) find that outside South Africa, roads and rail are often in a poor state, border crossings are frequently slow, and traders are subject to uneven and arbitrary bureaucratic treatment by border officials and police. They estimate that the effective speed of road transport in Southern Africa is between 6 and $12 \mathrm{~km}$ per hour. Rail transport is even worse with an effective speed of $4 \mathrm{~km}$ per hour on some routes. 
Figure 14. Transport infrastructure compared to OECD average
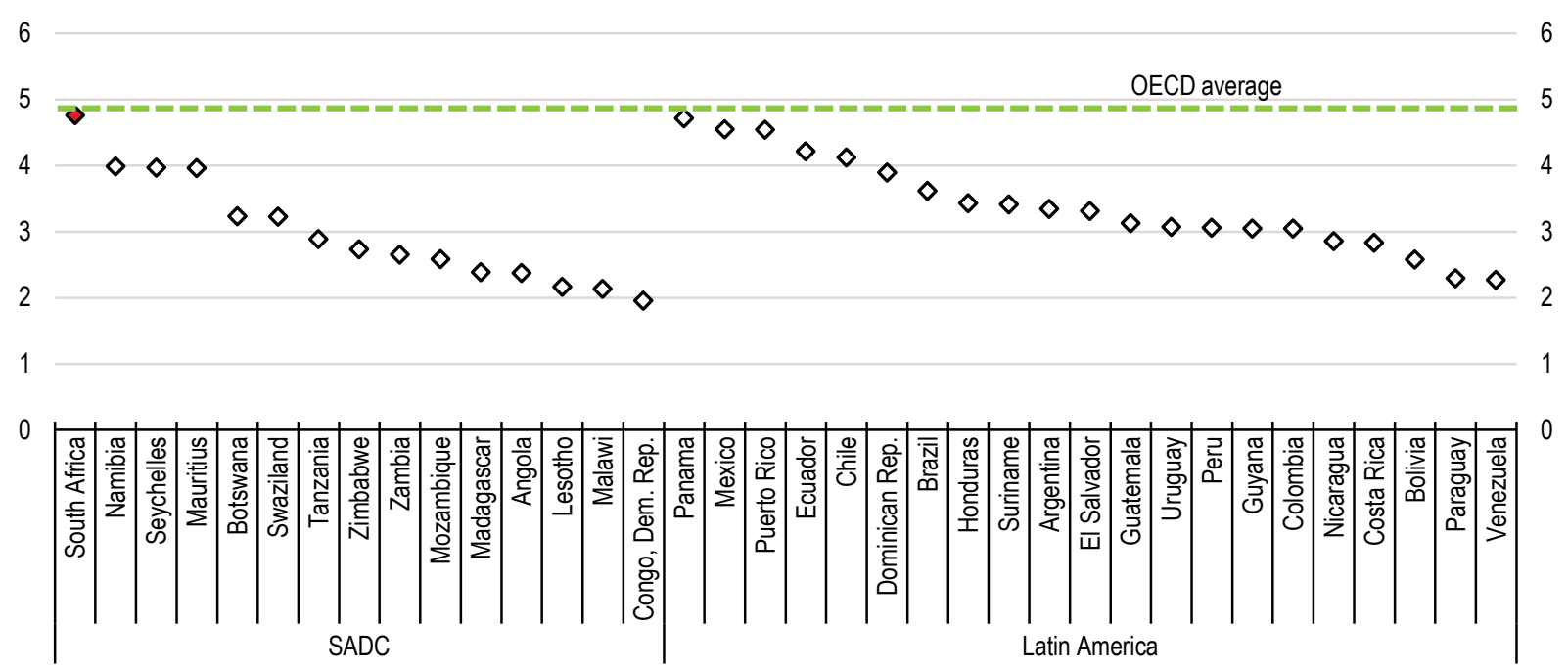

Source: World Economic Forum, Global Competitiveness Report.

At the regional level, there are different policies and initiatives to tackle the infrastructure needs. Strategic plans have been developed and agreed in all areas of infrastructure (transport, energy, meteorology, ICT, tourism and water). The aim is to upgrade the infrastructure, address the deficit and enhance quality. Also, improving maintenance of existing infrastructure and developing cross-border infrastructure and connection are among the top objectives.

Some progress has been made on most of these objectives. For instance, road agencies have been established in almost all countries, easing the collaboration between member countries. Intra-region transport corridors (around 18) have been identified and progress made on feasibility studies and costing (see Figure A.1 in Annex 4). For instance, the highway linking South Africa to Mozambique (Maputo development corridor connecting the port of Maputo to South Africa and Swaziland) has been built with the participation of the private sector (SADC, 2015b). In the energy sector, the creation of the Southern African Power Pool helped accelerate regional co-operation resulting in the establishment of the power trading platform and the connection of 9 of the 12 mainland SADC countries to the regional grid. This has helped, in the last years, imports of electricity from Mozambique to South Africa when the country was facing deep electricity shortage.

More focus should also be put on policies that could lower the cost of infrastructure-related services. Lack of progress on the liberalisation of road transport and the harmonisation of regional policies and regulation remains an important bottleneck (Cronjé (2015). Promoting more competition in the transport sector and harmonising rules across countries will lower the cost of transport and facilitate trade and industrial development. Vilakazi and Paleo (2017a) find that rates charged for goods transport can double between routes depending on the degree of competition. In routes with more competition, for instance between Lusaka and Johannesburg, prices are lower compared to the routes from Lilongwe to Maputo and Beira with weak competition. Vilakazi and Paleo (2017b) also show that there are still enormous differences in terms of rules and conditions of access to the transport market across member countries.

One of the main issues for the development of infrastructure is the funding. For instance, the SADC Regional Infrastructure Development Master Plan estimated capital requirements of USD 500 billion for regional infrastructure. SADC members have agreed to set up a Regional Development Fund as a financing 
mechanism for economic development and sustainable growth in SADC. The agreement to operationalise the Fund was signed in August 2016 aiming at an initial capital of thirteen billion dollars (SADC, 2016a). Accelerating the ratification of the agreement and subscription of the capital is necessary for the commencement of operations by the Fund.

Participation of the private sector in the financing of needed cross-border infrastructure would help in filling the funding gap. This requires the harmonisation of domestic and regulatory frameworks among countries, for instance by adopting common criteria for bid selection and evaluation, aligning national standards for oversight and transparency of the procurement process (OECD, 2013). Furthermore, transparent pricing and tariff regulations are necessary to attract private participation for instance in crossborder toll roads.

\section{Developing a comprehensive regional investment framework}

Investment is a key dimension of regional integration. The limited availability of capital and the large investment needs call for attracting foreign investment in almost all SADC countries. To foster investment across member countries and attract foreign investment, SADC countries have signed a Protocol on Finance and Investment (FIP) in 2006. Investment has risen subsequently along with the acceleration of trade between SADC members. Inward investment in SADC has grown at a faster pace than world investment flows (Figure 15).

Figure 15. SADC experienced a rapid increase of inward investment over the past 15 years

FDI flows.

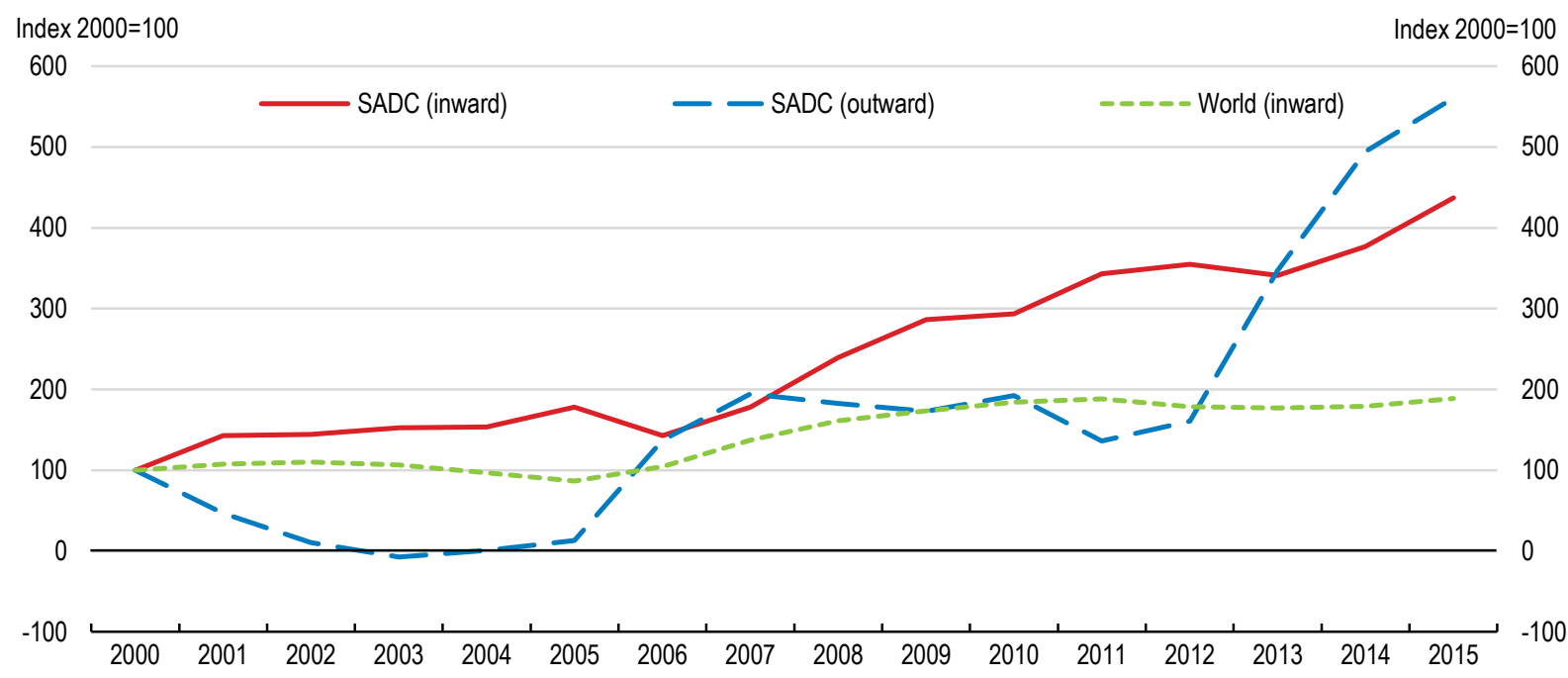

Note: FDI flows correspond to 5-year moving average, where the reported year corresponding to the latest of the 5 years.

Source: UNCTAD, World Investment Report 2016.

Despite the signature of the SADC Protocol on investment and financial integration, bottlenecks to investment inside the region remain high. In 2012, the SADC Secretariat developed a model of bilateral investment treaties to harmonise them across the region and help member countries in designing them (SADC, 2012). Furthermore, the SADC Regional Investment Policy Framework has been developed recently, in co-operation with the OECD and NEPAD, to accelerate the harmonisation and implementation of investment policies in the region. 
However, investment flows across and toward SADC are still low (Figure 16). The stock of crossregional investment is lower than in other regional economic communities (RECs) in Asia and Latin America. Nevertheless, inward and outward investment in SADC is significantly higher relative to the Economic Community of West African States. The flow of investments from South Africa is rising sharply in selected SADC countries. The decomposition of FDI stocks into cross-border investments from within the region versus outside the region show negligible intra-regional investment flows until 2010. In 2014, the share of cross-regional investment in total FDI has risen to 5\% and 12\% for inward and outward FDI stocks, respectively. This is still low compared to regional economic communities in Asia, but outperforms regional economic communities in Latin America and West Africa.

There is a difference between intra-regional and international investments. FDI flows into the SADC region have been concentrated in natural resource sectors (OECD, 2017b). Most greenfield investments in five SADC member countries (Botswana, Mauritius, Mozambique, Namibia and South Africa) between 2003 and 2015 went into the extraction of coal, oil, natural gas, and metals (OECD, 2016). Foreign investment remains low in manufacturing both in terms of share in total and absolute terms (OECD, 2017a). Intra-regional investments have been mostly driven by the development of regional value chains in the services sector (supermarket, banking, etc.). 
Figure 16. FDI position of SADC relative to other regional economic communities

Inward and outward FDI positions by regional cluster: 2010 and 2014 (in USD billion)

$\square$ Regional

$\square$ Non-regional

A. Inward FDI positions

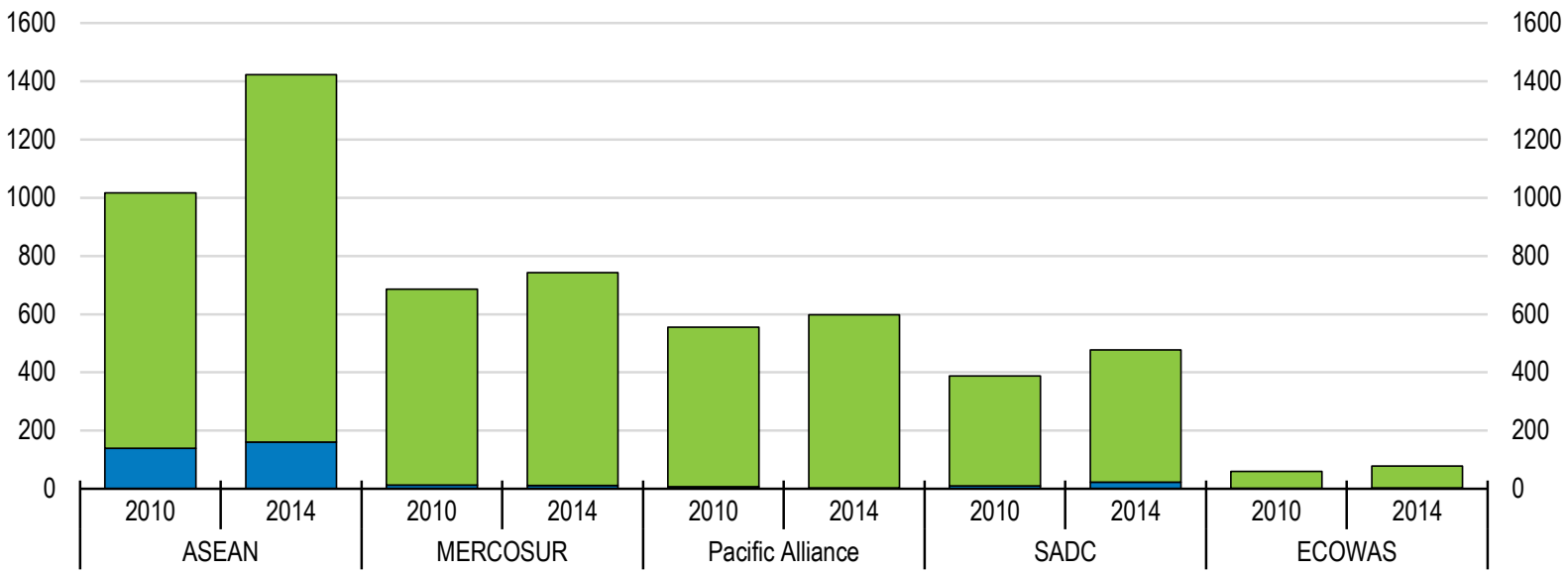

B. Outward FDI positions

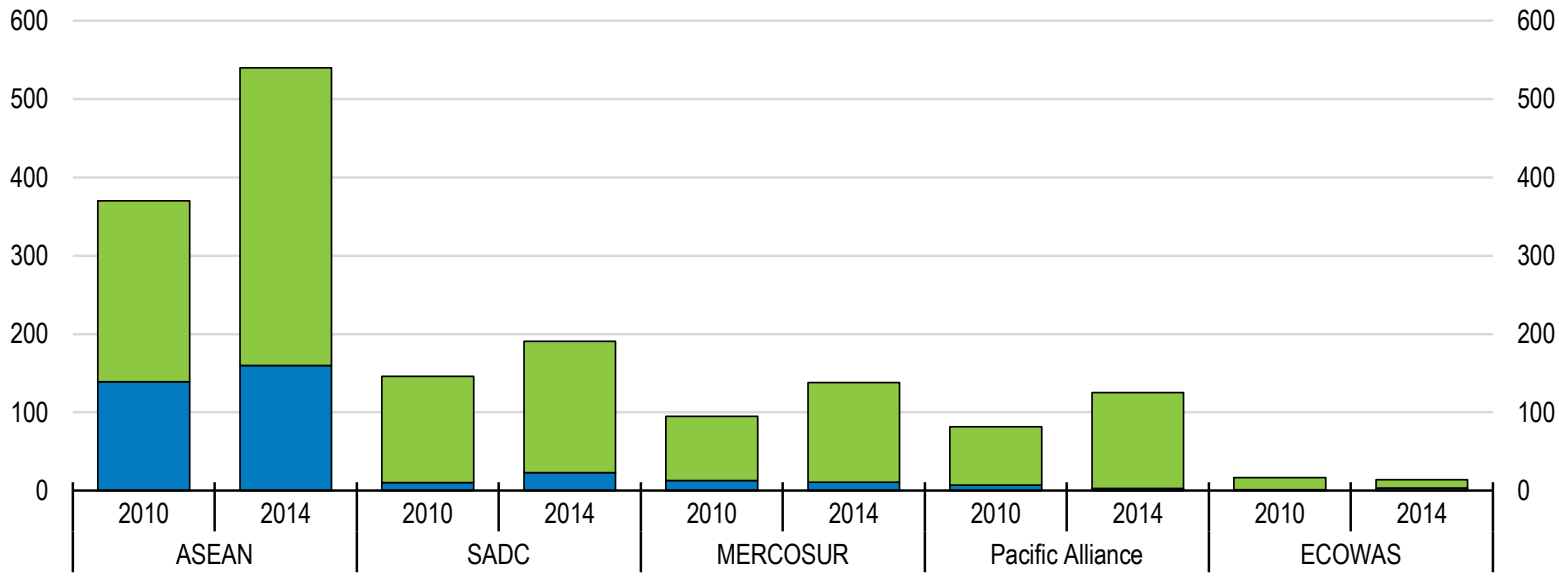

Source: OECD report on "Regional Global Value Chains in SADC," 2017, data based on IMF (2016), Coordinated Direct Investment Survey (CDIS).

In particular, the Regional Investment Policy Framework addresses 5 policy areas that have emerged as priorities for regional co-operation: coherent and transparent investment environment; market access and competition; security and protection of investors' rights; responsible and inclusive investment and regional and international integration (SADC / OECD, 2017a). Incorporating the regional framework into domestic reforms is crucial for the implementation of the Regional Investment Policy Framework.

A SADC / OECD (2017b) benchmarking exercise confirmed that reforming the framework conditions and improving the infrastructure environment are essential to attract investment and to make SADC as attractive as other emerging regions such as ASEAN for investors. For instance, in terms of the number of days to start a business, it takes many more days to set up a firm in SADC than in any other region in the world, with the exception of MERCOSUR. The extent of these reforms varies across SADC Member States (SADC / OECD, 2017b). Establishing a central point to co-ordinate and systematically gather 
comprehensive, up-to-date information on all laws, regulations, incentive schemes, and procedures related to investment, is necessary in the region to increase attractiveness.

In terms of market access, restrictions on foreign investment have increased in recent years. FDI and other cross-border investment restrictions appear to be relatively high in SADC compared with other regions. The high average for SADC is driven to a certain extent by the recent restrictions on cross-border investment introduced by South Africa (SADC / OECD, 2017b). SADC countries should provide equal competitive opportunities for both foreign and national investors and be transparent with up-to-date information on existing restrictions justified by national goals (promotion of disadvantaged groups).

\section{Further integration of the financial system will ease financing conditions across countries}

The financial sector in SADC is diverse and fragmented. South Africa and Mauritius have highly developed financial systems, while Congo D. R. and Tanzania have small and underdeveloped ones (Table 4). Affordable capital across most of the region is scarce, as high risk premiums associated with political and macroeconomic uncertainty drive up costs (World Bank, 2007; AfDB, 2013; SWIFT 2013). Currency conversion costs are high; and most countries still have restrictive exchange and capital control regulations in place (IMF, 2016). Therefore, intra-SADC trade and capital movement remains below its potential, with most businesses finding it easier to source and move capital from outside the continent to support intra-African transactions than within (AfDB, 2013, SWIFT 2013).

Out of the five indicators tracked to assess regional integration on the continent, the financial and macroeconomic integration sub-index has the lowest overall score across all regional economic centres (African Union Commission et al., 2016). Not surprisingly, the index shows that within SADC, financial integration of domestic markets is low. Deeper regional integration can help overcome current issues of scale and development, enable risks to be better managed, make markets more efficient and improve the allocation of capital.

Table 4. Indicators of financial depth and size, 2014

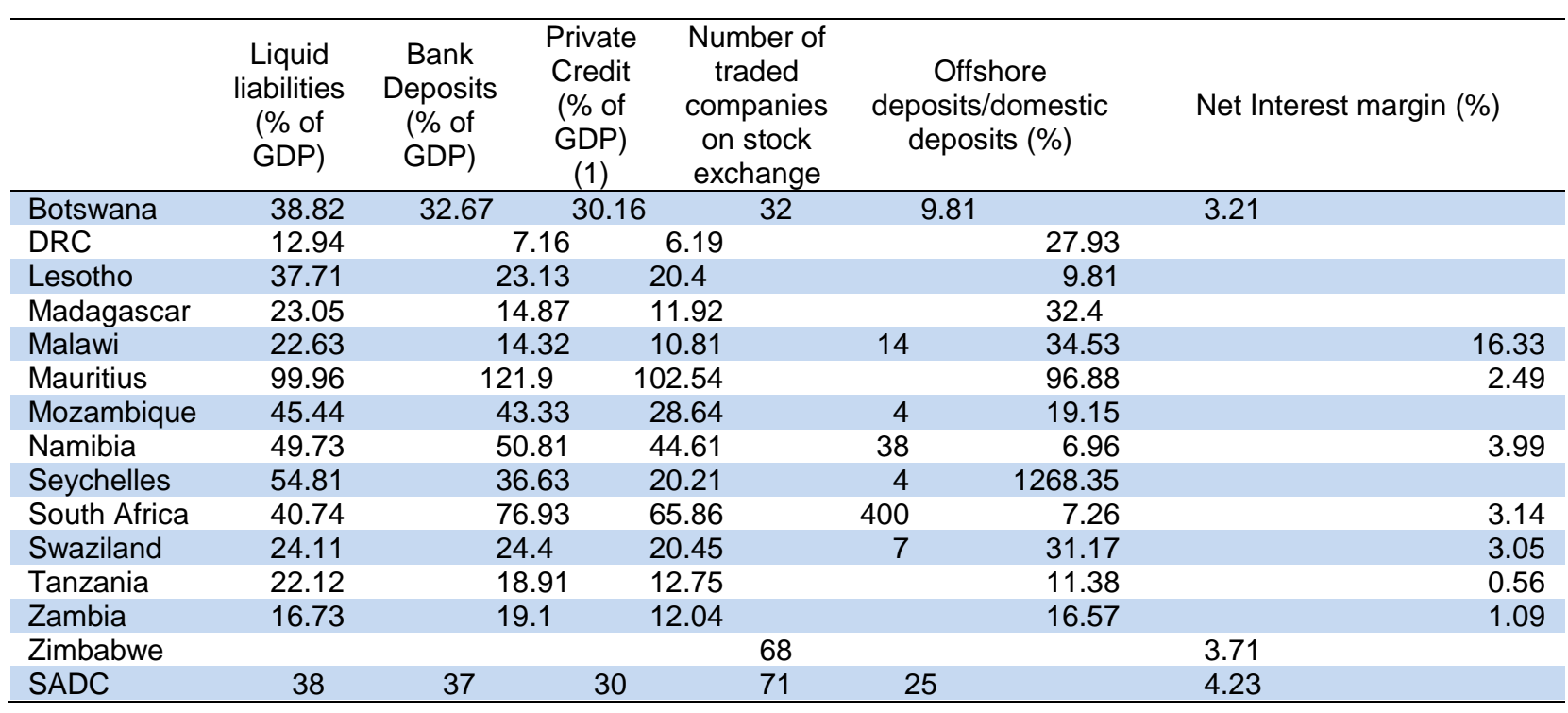

Note: (1) Credit extended by deposit money banks. Numbers marginally higher for Zimbabwe (15.82) and Seychelles (22.11) if lending by other institutions are included and significantly higher for South Africa (147.28).

Source: World Bank Financial Development and Structure Dataset, 2015. Committee of SADC Stock Exchanges. 
Cross-border transactions face different regulatory frameworks within SADC. To deal with this, SADC has put in place memoranda and guidelines to improve coordination, to harmonise the systems and to establish common regional frameworks for foreign exchange transactions, capital controls, banking procedures and systems and other financial matters (SADC, 2006; SADC, 2009; SADC, 2011). SADC has also developed a model of central bank law that aims to facilitate the operational independence of central banks and create clear standards of accountability and transparency (SADC, 2009 and SADC, 2011). However, these are not binding. Moreover, the memoranda and guidelines often result in countries agreeing or implementing reforms at the lowest common denominator. Encouragingly, an application to harmonise banking supervision processes has been implemented by 14 countries.

A regional cross-border settlement system, the Integrated Regional Electronic Settlement System (SIRESS) was introduced in 2013 to enhance greater financial integration within the region. SIRESS was first piloted in the four Common Monetary Area countries that use the South African Rand (South Africa, Lesotho, Namibia and Swaziland) and was later rolled out to other member countries. The system allows for real-time settlement of payment transactions between countries based on a single currency - the South African rand. The system is operated by the South African Reserve Bank (SARB) on behalf of the SADC Committee of Central Bank Governors, with the National Payment System Act of South Africa providing the legal framework for the system. While the system is managed by the SARB, ownership and decision-making processes fall under the governance structures of the Committee of Central Bank Governors.

Prior to the introduction of SIRESS, cross border payments in the region were mostly in US Dollars, often resulting in a double round of exchange costs (SWIFT 2013). For example, South African sending money to Botswana would have to first convert from rand to dollars, then from dollars to pula, incurring transaction fees and commissions. Following SIRESS, transfers now only face one currency exchange without any commission and are instant.

The exact impact of SIRESS on weakening the use of the dollar and facilitating greater trade is difficult to assess as there is limited access to data. However, the higher than average ranking for financial integration in SADC relative to other customs unions in the 2016 World Bank sub-index for financial market integration (that includes a measure of currency convertibility) suggests that SIRESS has played an important role in improving currency convertibility and deepening financial integration since its introduction in 2013 (Figure 17). 
Figure 17. Financial Integration Index
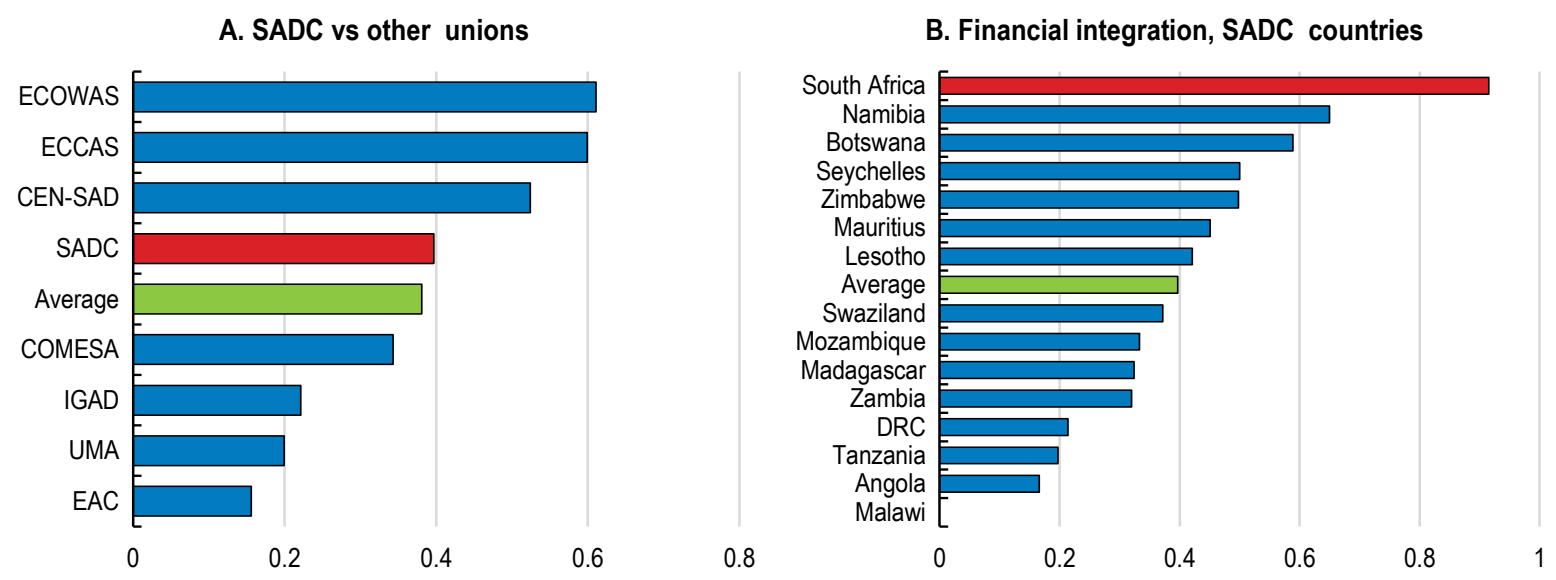

Note: Index of two indicators: Regional convertibility of national currencies and Inflation rate differentials (based on the Harmonised Consumer Price Index).

Source: Africa Union Commission et al., Africa Regional Integration Index (2016).

The introduction of SIRESS is a great first step to create foundations for greater integration. By ensuring that settlements are done through the banking system, SIRESS has the potential to improve the monetary base within the region. The interbank nature of the system also facilitates the establishment of a regional short-term money market, with the potential to lower rates and increase transparency and broaden access to credit. Finally, as the use of the rand as the base currency presents some challenges due to the trade imbalance between South Africa and the other countries, SADC countries are considering making SIRESS a multi-currency payment system. Over time, the use of a single currency in SIRESS presents opportunities to eliminate exchange risk associated with cross-border transactions and enhance intra-SADC trade and investment by making it easy to transact.

In addition to traditional bank transfers and SIRESS, the region has made progress in easing remittances between individuals across SADC countries. Money transfer operators such as MoneyGram and Western Union and retail stores such as Shoprite and PicknPay have taken advantage of existing networks, partnerships, infrastructure and widely used technology such as mobile money to facilitate the ease of cross-border transfers for individuals (Hope, 2016). Cross border SADC regulation does not exist for money transfer, neither is there much harmonisation between countries.

However, this has not always deterred further expansion of these services or the creation of new payment corridors. The creation of a new financial licence category in 2015 in South Africa made it possible for non-bank institutions to become money transfer operators. New market participants and the creation of a special money transfer corridor between South Africa and Zimbabwe have made regulatory barriers between countries less binding for financial mobility. Further facilitating money transfers between countries through non-financial institutions accompanied by appropriate regulations have the potential to boost financial integration.

\section{There is scope for strengthening tax cooperation}

Since the adoption of the first SADC memorandum of understanding in 2002, corporate and VAT rates have been reduced across the region and some countries have been trying to rationalise investment 
tax incentives. However, tax regimes across the region remain complex with large differences in the effective tax rates across different sectors and economic zones (Table 5).

Corporate tax rates have declined across most countries over the last decade, in line with global trends. However, statutory corporate rates across most SADC member states remain above the regional average of $28 \%$ with alternative minimum rates for some sectors or special economic zones. The OECD average is $25 \%$ (range of 8.5 to $35 \%$ ). Similarly, personal income taxes and payroll taxes still differ quite significantly across SADC member states. In contrast, there is some convergence in VAT rates and the zero-rating of exports, but VAT systems still differ with respect to standard, zero-rated and exempt goods. Despite differences in zero-rated and exempt goods, 10 of the member states have VAT rates between 14 and $16 \%$, and three of five SACU countries have a fairly unified VAT regime. In response, SADC has developed a Guideline for VAT that proposes a minimum standard rate of $10 \%$, discourages the use of multiple tax rates and, instead, encourages the use of an ad-valorem excise tax for goods requiring a higher tax rate than the standard VAT rate (SADC, 2016b). While SADC aims to gradually harmonise the application of zero rating and exemption of goods, specific guidelines have yet to be set. The application and rates of other indirect taxes such as excise duties and other local taxes also remains fairly varied, despite the guidelines set out in the memoranda.

Tax incentives across the region are also varied and complex, differing by sector, investment types, activity, location, domestic and foreign ownership and size of investment. Like corporate income tax rates, tax incentives tend to favour companies investing in the mining, manufacturing and tourism sectors and those located in special economic and exporting zones.

Table 5. Summary of major tax rates across SADC ${ }^{1}$

\begin{tabular}{|c|c|c|c|c|c|c|c|}
\hline & \multicolumn{4}{|c|}{ Main tax rates } & \multicolumn{3}{|c|}{ Alternative minimum corporate income tax rates } \\
\hline & $\begin{array}{c}\text { Personal } \\
\text { Income tax } \\
(\%)^{2}\end{array}$ & $\begin{array}{c}\text { Value } \\
\text { added } \\
\operatorname{tax}(\%)\end{array}$ & $\begin{array}{c}\text { Payroll } \\
\text { taxes } \\
(\%)^{3} \\
\end{array}$ & $\begin{array}{c}\text { Corporate } \\
\text { income tax } \\
(\%)^{4}\end{array}$ & $\begin{array}{c}\text { Mineral } \\
\text { resources }(\%)^{5}\end{array}$ & Manufacturing ${ }^{5}$ & $\begin{array}{c}\text { Special } \\
\text { economic } \\
\text { zones }^{6}\end{array}$ \\
\hline Angola & 17 & 10 & 8 & 30 & $25-65.75$ & & \\
\hline Botswana & 25 & 12 & 0.2 & 22 & $22-55$ & 15 & 15 \\
\hline DRC & 40 & 16 & 11.2 & 35 & 30 & & \\
\hline Lesotho & 30 & 14 & 0 & 25 & & 10 & \\
\hline Madagascar & 20 & 20 & 18 & 20 & & & 10 \\
\hline Malawi & 30 & 17 & 8.5 & 30 & & & \\
\hline Mauritius & 15 & 15 & 10 & 15 & & & 0 \\
\hline Mozambique & 32 & 17 & 4 & 32 & & & \\
\hline Namibia & 37 & 15 & 1.9 & 32 & $35-55$ & 18 & 0 \\
\hline Seychelles & 15 & 15 & 2 & 25 & & & \\
\hline South Africa & 41 & 14 & 2 & 28 & & & 15 \\
\hline Swaziland & 33 & 14 & 5.5 & 28 & & & \\
\hline Tanzania & 30 & 18 & 16 & 30 & & & 0 \\
\hline Zambia & 35 & 16 & 9.2 & 35 & 30 & 0 & 0 \\
\hline Zimbabwe & 25 & 15 & 5 & 26 & 15 & $15-20$ & 0 \\
\hline
\end{tabular}

Note: (1) See table A.5 in Annex for detailed precision on rates. (2): Top marginal or flat rate. (3) The sum of wage contributions and tax based on the payroll, except in Botswana where the base is company turnover. (4) Statutory rate- top or flat, effective rate including surtax for Zimbabwe. (5) General preferential sector rates or rate applicable to select companies or subsectors within industry. (6) Refers to special economic, export processing zones or any other geographic or legal area that functions with a different fiscal regime to the norm.

Source: OECD compilation.

A certain degree of tax competition exists between SADC countries in particular with respect with special economic zones, tax incentives and advantages accorded to investors without transparency in the criteria. This applies in particular to mining, manufacturing and tourism sectors and special economic and 
export zones. Countries like South Africa, Mauritius and Tanzania also seem to be competing in incentivising companies to set up headquarters.

In an effort to foster greater tax uniformity, incentivise investment and minimise harmful tax competition within the region, SADC has developed guidelines on taxation with specific recommendations relating to the treatment of VAT, excise, customs and tax incentives (SADC, 2002; SADC, 2006; SADC 2016b). The guidelines aim to achieve greater tax transparency, convergence in tax rates across countries, a common approach in the treatment of indirect taxes and incentives, and the substitution of taxes on internationally traded goods with a broad-based consumption tax.

VAT coordination could encourage greater economic integration and limit trade diversion. SADC should develop a standardised maximum list of exemptions and rates of VAT. The SADC guideline on VAT should have mandatory dimension with specific deadlines by which countries should comply, in line with international best practice. This has the benefit of lowering compliance and enforcement costs, and promoting the free movement of goods and trade within the region. An example of successful coordination of VAT is the EU where member states have the freedom to set the number and level of VAT rates but subject to rules which prescribe the minimum standard rate, the number of reduced rates, and the set of goods and services to which they apply.

\section{Box. Key recommendations for deepening regional integration within SADC}

- Reduce non-tariffs barriers on intra-regional trade. Harmonise where possible documents for licences, price control measures and technical barriers to trade (technical norms).

- Simplify and adopt a unique set of rules of origin in the forthcoming tripartite free trade area.

- Lead the harmonization of competition rules among SADC countries and increase cooperation between competition authorities.

- Promote competition in infrastructure-related services across countries.

- Create a specific infrastructure fund and increasing private sector participation in infrastructure development.

- Provide special economic zones with better infrastructure and develop their linkages with local economies.

- Upgrade information technology at custom posts and improve the interconnectivity of systems and generalise one-stop border control point between SADC members.

Further recommendations

- Align and co-ordinate VAT rates. Develop a standardised maximum list of exemptions and reduced rates of VAT and make guidelines with specific deadlines by which countries should comply.

- Facilitate the mobility of workers and business people within SADC.

- Reform the framework conditions for doing business to attract more investment.

- Limit the number of procedures, documents and time to set up a business.

- Accelerate the creation of the regional development fund and subscription of the capital necessary for the commencement of operations by the Fund.

- Reform the sharing formula of SACU and mechanism of tariff settings to facilitate further custom policy harmonisation within SADC.

- Establish a central point to co-ordinate and systematically gather comprehensive, up-todate information on all laws, regulations, incentive schemes, and procedures related to investment. 


\section{REFERENCES}

Abreu, M. D. (2013), "Preferential Rules of Origin in Regional Trade Agreements", Staff Working Paper ERSD-2013-05, World Trade Organisation.

African Development Bank Group (2013), "Regional Integration Brief: Intra-SADC cross-border investments", https://www.afdb.org/fileadmin/uploads/afdb/Documents/Publications/Regional_Integration_Brief__Intra-sadc_cross-border_investments.pdf

AfDB (African Development Bank), OECD, and United Nations Development Programme (2014), African Economic Outlook 2014: Global Value Chains and Africa's Industrialisation. Paris: UN Economic Commission for Africa.

African Union Commission, African Development Bank and Economic Commission for Africa (2016), "Africa Regional Integration Index". https://www.integrateafrica.org/fileadmin/uploads/afdb/Documents/ARII-Report2016_EN_web.pdf

Anderson, J. E. and E. van Wincoop (2003), "Gravity with Gravitas: A Solution to the Border Puzzle," American Economic Review, Vol. 93(1), pages 170-192.

Anderson, J. E. and Y. V. Yotov (2010) "The Changing Incidence of Geography", American Economic Review, Vol. 100, 2157-86.

Arvis, J.-F., Y. Duval, B. Shepherd, C. Utoktham, A. Raj (2016), “Trade costs in the Developing World: 1996-2010", World Trade Review, Vol. 15:3, 451-474.

Balistreri, E. J. and R. H. Hillberry (2007), "Structural estimation and the border puzzle," Journal of International Economics, Vol. 72(2), pages 451-463.

Brenton, P., Flatters F. and P. Kalenga (2005), "Rules of Origin and SADC: The case for change in the mid-term review of the Trade Protocol", Africa Region Working Paper Series, No. 83. Washington: World Bank.

Byiers, B., and J. Vanheukelom (2014), "What Drives Regional Economic Integration? Lessons from the Maputo Development Corridor and the North-South Corridor", European Centre for Development Policy Management Discussion Paper, No 157.

Cadestin, C. and F. Fall (forthcoming), "Effectiveness of Trade Policies in SADC Compared to Other Regional Communities", OECD Economics Department Working Paper, forthcoming.

Calderón, C. and L. Servén (2008), "Infrastructure and Economic Development in Sub-Saharan Africa", Policy Research Working Paper, No. 4712. World Bank, Washington, DC.

Cronjé, J.B. (2015), 'The road transport sector in the context of the SADC Protocol on Transport, Communications and Meteorology', TRALAC Working Paper, S15WP07/2015

Cronjé, J.B. (2014), "The SADC Protocol on Trade in Services: What is necessary to support the establishment of an integrated market?", TRALAC Working Paper, S14WP05/2014 
Dee, P. et al. (2011), “The Impact of Trade Liberalisation on Jobs and Growth: Technical Note”, OECD Trade Policy Working Papers, No. 107, OECD Publishing. doi: 10.1787/5kgj4jfj1nq2-en

Dee, P. and C. Findlay (2008), “Services: A Deal-Maker in the Doha Round?" in B. Blonigen (ed.), Monitoring International Trade Policy: A New Agenda for Reviving the Doha Round, Kiel Institute and Centre for Economic Policy Research.

Dihel, N. and A. G. Goswami (2016), "From Hair Stylists and Teachers to Accountants and Doctors: The Unexplored Potential of Trade in Services in Africa", Edited by Nora Dihel and Arti Grover Goswami, World Bank Group, 2016.

Erasmus, G. (2015), "The Tripartite Free Trade Agreement: Results of Phase One of the Negotiations", TRALAC Working Paper, No US15WP04/2015.

Escribano, A., J. L. Guasch and J. Pena (2010), “Assessing the Impact of Infrastructure Quality on Firm Productivity in Africa", Policy Research Working Paper, No 5191, World Bank.

EU (2006), "Directives on services in the internal market". http://eur-lex.europa.eu/legalcontent/EN/TXT/?uri=CELEX:32006L0123.

Factset (2016), "A comprehensive and up-to-date database of material intercompany relationships", www.factset.com/data/company_data/supply_chain

Fall, F., B. Vachon and C. Winckler (2014), "Regional Integration: Comparison Between SADC and ECOWAS", Regional Economic Integration in West Africa, Advances in African Economic, Social and Political Development, Springer International Publishing, Switzerland. doi: 10.1007/978-3-31901282-7_9

Fally, T. (2015), "Structural Gravity and Fixed Effects", Journal of International Economics, 97, 76-85.

Farole, T. (2011), "Special Economic Zones in Africa: Comparing Performance and Learning from Experience", World Bank, Washington.

Feenstra, R. (2004), “Advanced International Trade”, Princeton University Press.

Flatters, F. and M. Stern (2006), "SACU Revenue Sharing: Issues and Options", http://qed.econ.queensu.ca/faculty/flatters/writings/ff\&ms_sacursf_2006.pdf

Foster, V. and C. Briceño-Garmendia (2010), Africa's Infrastructure: A Time for Transformation, Ed., World Bank, Washington D C

Fundira, T. (2017), "Implementing the SADC EPA- Challenges and impact", TRALAC Discussion Note, 01 March 2017, https://www.tralac.org/discussions/article/11348-implementing-the-sadc-epachallenges-and-impact.html\#ftn3

Harrigan, J. (1996), "Openness to trade in manufactures in the OECD, "Journal of International Economics, Vol. 40(1-2), pages 23-39, February.

Head, K., and T. Mayer (2015), "Gravity Equations: Workhorse, Toolkit, and Cookbook", Handbook of International Economics, Vol. 4, eds. Gopinath, Helpman, and Rogoff. 
Hope, A. (2016), "Moving Money Across Borders in the SADC Region", TRALAC Trade brief, No S16TB16/2016.

Industrial Development Corporation (2016). "Clothing and textiles: stabilising a challenging sector", accessed 16-04-2017. http://www.idc.co.za/20years/making-an-impact/clothing-and-textiles

IMF (2016), "Annual Report on Exchange Arrangements and Exchange restrictions", https://www.imf.org/en/Publications/Annual-Report-on-Exchange-Arrangements-and-ExchangeRestrictions/Issues/2017/01/25/Annual-Report-on-Exchange-Arrangements-and-ExchangeRestrictions-2016-43741

Jensen, H. G. and R. Sandrey (2016), "Continental Wide Service Liberalization within Africa", TRALAC Working Paper, S16WP20/2016

Kowalski, P. et al. (2015), "Participation of Developing Countries in Global Value Chains: Implications for Trade and Trade-Related Policies", OECD Trade Policy Papers, No. 179, OECD Publishing, Paris. http://dx.doi.org/10.1787/5js33lfw0xxn-en

Krugman, P. (1979), "Increasing returns, monopolistic competition, and international trade", Journal of International Economics, Vol. 9(4), 469-479.

Krugman, P. (1980), "Scale Economies, Product Differentiation, and the Pattern of Trade", American Economic Review, Vol. 70(5), 950-59.

Lewis, C. and B. Gasealahwe (2017), "Lowering barriers to entrepreneurship and promoting small business growth in South Africa", OECD Economics Department Working Paper 150.

Mevel, S., G. Valensisi and S. Karingi (2015), "The Economic Partnership Agreements and Africa's integration and transformation agenda: the cases of West Africa and Eastern and Southern Africa regions", UNECA.

Ncube et al. (2016), "Development of the animal feed to poultry value chain across Botswana, South Africa, and Zimbabwe", UNU-WIDER Working Paper, 2016/2.

Newman, C., et al. (2016), "Made in Africa: Learning to Compete”, Ed., Brooking Institution Press, Washington D.C.

Novy, D. (2012), 'Gravity Redux: Measuring International Trade Costs with Panel Data', Economic Inquiry, Vol. 51(1):01- 121.

OECD (2017a), "Mapping supply chain investments in Southern African Development Community and the world", presented at SADC Investment Focus Group Meeting in Swaziland, March 2017, forthcoming.

OECD (2017b), OECD Economic Surveys: South Africa 2017, OECD Publishing, Paris.

OECD (2015), OECD Economic Surveys: South Africa 2015, OECD Publishing, Paris.

OECD (2013), "Increasing private participation in the Southern African Development Community's infrastructure: Policy bottlenecks and the way forward". https://www.oecd.org/daf/inv/investmentpolicy/IncreasingPrivateParticipationInSADCinfrastructure.pdf 
Redding, S. and A. J.Venables (2004), "Economic geography and international inequality", Journal of International Economics, Vol. 62(1): 53-82.

SADC and OECD (2017a), "The SADC Regional Investment Policy Framework - A regional Action Plan for inclusive and productive investment", OECD forthcoming.

SADC and OECD (2017b), "Role of Monitoring for Implementation: Advancing Investment Policy Reforms in the SADC", SADC Investment Focus Group Meeting February 2017, forthcoming.

SADC (2016a), "Agreement on the operationalisation of the SADC Regional Development Fund". https://www.tralac.org/images/Resources/SADC/Agreement\%20on\%20the\%20Operationalisation\% 20of\%20the\%20SADC\%20Regional\%20Development\%20Fund\%202016\%20English.pdf

SADC (2016b), "Guidelines for Co-operation in Value Added Taxes in the SADC Region", https://www.sadc.int/files/4114/7618/6109/SADC_VAT_Guidelines_and_Commentary_Published_ October_2016_English.pdf

SADC (2015a), "Revised Regional Indicative Strategic Development Plan (RISDP) 2015-2020", https://www.tralac.org/publications/article/9173-revised-risdp-a-new-growth-path-for-sadc-sindustrial-development.html

SADC (2015b), "SADC@35: Success stories", https://www.sadc.int/files/8914/4007/4304/SADC_Success_Stories_final_English_PDF_3.pdf .

SADC (2012), "SADC Model Bilateral Investment Treaty Template with Commentary". https://www.tralac.org/images/Resources/SADC/SADC_Model_Bilateral_Investment_Treaty_Temp late_with_Commentary_July_2012.pdf

SADC (2011a), "SADC Explanatory Guide to the SADC Central Bank Model Law". https://www.sadcbankers.org/Lists/News\%20and\%20Publications/Attachments/118/Model_Law(En glish2009)_SADC\%20Central\%20Bank\%20Model\%20Law.pdf

SADC (2011b), "Sub-Committee on Customs Co-operation: Indicative Strategic Plan", July 2011. http://www.sadc.int/files/4213/7415/0105/SCCC_Strategic_Plan_2012_-_2016.pdf

SADC (2011c), "Technical Report: 2011 Audit of the Implementation of Regional SADC Customs Instruments and international Conventions". http://www.sadc.int/files/5413/7415/0039/Customs_Audit_2011.pdf

SADC (2009), "SADC Central Bank Model Law". https://www.sadcbankers.org/Lists/News\%20and\%20Publications/Attachments/118/Model_Law(En glish2009)_SADC\%20Central\%20Bank\%20Model\%20Law.pdf

SADC (2006), "SADC Protocol on Finance and Investment". http://www.sadc.int/files/4213/5332/6872/Protocol_on_Finance_Investment2006.pdf

SADC (2003), "Rules of Origin: Exporters Guide Manual". http://www.sadc.int/files/9613/5413/6410/3._Rules_of_Origin_Exporters_Guide_Manual.pdf

SADC (2002), "Memorandum of Understanding in Co-operation in Taxation Related Matters", http://www.sadc.int/files/4413/5333/7922/Memorandum_of_Understaning_in_Cooperation_in_Taxa tion_Related_Matters.pdf 
Sandrey, R. (2015), "Rules of origin - looking outside the box", TRALAC Working Paper, US15WP03/2015

Santos Silva, J. and S. Tenreyro (2006), "The Log of Gravity", Review of Economics and Statistics, Vol. 88, No. 4, Pages 641-658.

Schiff, M. and L. A. Winters (2003), "Regional integration and development", World Bank, Washington D.C.

Shayanowako, P. (2015), "The role of customs management in the facilitation of trade in the region", TRALAC Working Paper, S15WP05/2015

SWIFT (2013), "Africa Payments: Insights into African transaction flows", https://www.swift.com/node/14411

Tinbergen, J. (1962), "Shaping the World Economy: Suggestions for an International Economic Policy", New York: The Twentieth Century Fund.

UNCTAD (2015), "Non-Tariff Measures and Regional Integration in the Southern African Development Community". http://unctad.org/en/PublicationsLibrary/ditctab2014d5_en.pdf

Vilakazi, T., and A. Paelo (2017a), "Understanding Intra-Regional Transport towards the Integration of Markets: Competition in Road Transportation between Malawi, Mozambique, South Africa, Zambia, and Zimbabwe", WIDER Working Paper, 2017/46.

Vilakazi, T., and A. Paelo (2017b), "Transport towards the Integration of Markets: Competition in road transportation of perishable goods between Malawi, South Africa, Zambia, and Zimbabwe", WIDER Working Paper, 2017/49

World Bank (2007), "Financial Sector Integration in two regions in Sub-Saharan Africa", http://siteresources.worldbank.org/INTAFRSUMAFTPS/Resources/Working_Paper_on_Regional_F inancial_Integration_Jan07.pdf 


\section{ANNEX 1}

\section{Export products in SADC}

Table A.1 List of exported products in table 1

\begin{tabular}{|c|c|}
\hline Aircraft, spacecraft, and parts thereof & Aluminium and articles thereof \\
\hline $\begin{array}{l}\text { Animal or vegetable fats and oils and their cleavage } \\
\text { products; prepared edible fats; animal ... }\end{array}$ & $\begin{array}{l}\text { Articles of apparel and clothing accessories, knitted or } \\
\text { crocheted }\end{array}$ \\
\hline $\begin{array}{l}\text { Articles of leather; saddlery and harness; travel goods, } \\
\text { handbags and similar containers; articles ... }\end{array}$ & Beverages, spirits and vinegar \\
\hline Cereals & Cocoa and cocoa preparations \\
\hline Coffee, tea, maté and spices & Commodities not elsewhere specified \\
\hline Copper and articles thereof & Cotton \\
\hline $\begin{array}{l}\text { Dairy produce; birds' eggs; natural honey; edible products } \\
\text { of animal origin, not elsewhere ... }\end{array}$ & Edible fruit and nuts; peel of citrus fruit or melons \\
\hline $\begin{array}{l}\text { Electrical machinery and equipment and parts thereof; } \\
\text { sound recorders and reproducers, television ... }\end{array}$ & $\begin{array}{l}\text { Essential oils and resinoids; perfumery, cosmetic or toilet } \\
\text { preparations }\end{array}$ \\
\hline Fertilisers & $\begin{array}{l}\text { Fish and crustaceans, molluscs and other aquatic } \\
\text { invertebrates }\end{array}$ \\
\hline Footwear, gaiters and the like; parts of such articles & $\begin{array}{l}\text { Furniture; bedding, mattresses, mattress supports, } \\
\text { cushions and similar stuffed furnishings; ... }\end{array}$ \\
\hline $\begin{array}{l}\text { Inorganic chemicals; organic or inorganic compounds of } \\
\text { precious metals, of rare-earth metals, ... }\end{array}$ & Iron and steel \\
\hline Knitted or crocheted fabrics & Live animals \\
\hline $\begin{array}{l}\text { Machinery, mechanical appliances, nuclear reactors, } \\
\text { boilers; parts thereof }\end{array}$ & Meat and edible meat offal \\
\hline $\begin{array}{l}\text { Mineral fuels, mineral oils and products of their distillation; } \\
\text { bituminous substances; mineral ... }\end{array}$ & Miscellaneous chemical products \\
\hline $\begin{array}{l}\text { Natural or cultured pearls, precious or semi-precious } \\
\text { stones, precious metals, metals clad ... }\end{array}$ & Nickel and articles thereof \\
\hline $\begin{array}{l}\text { Optical, photographic, cinematographic, measuring, } \\
\text { checking, precision, medical or surgical ... }\end{array}$ & Ores, slag and ash \\
\hline Organic chemicals & Other base metals; cermets; articles thereof \\
\hline Plastics and articles thereof & $\begin{array}{l}\text { Preparations of meat, of fish or of crustaceans, molluscs } \\
\text { or other aquatic invertebrates }\end{array}$ \\
\hline $\begin{array}{l}\text { Preparations of vegetables, fruit, nuts or other parts of } \\
\text { plants }\end{array}$ & $\begin{array}{l}\text { Printed books, newspapers, pictures and other products } \\
\text { of the printing industry; manuscripts, ... }\end{array}$ \\
\hline $\begin{array}{l}\text { Products of the milling industry; malt; starches; inulin; } \\
\text { wheat gluten }\end{array}$ & $\begin{array}{l}\text { Residues and waste from the food industries; prepared } \\
\text { animal fodder }\end{array}$ \\
\hline $\begin{array}{l}\text { Salt; sulphur; earths and stone; plastering materials, lime } \\
\text { and cement }\end{array}$ & Ships, boats and floating structures \\
\hline Sugars and sugar confectionery & Tobacco and manufactured tobacco substitutes \\
\hline $\begin{array}{l}\text { Vehicles other than railway or tramway rolling stock, and } \\
\text { parts and accessories thereof }\end{array}$ & Wood and articles of wood; wood charcoal \\
\hline $\begin{array}{l}\text { Wool, fine or coarse animal hair; horsehair yarn and } \\
\text { woven fabric }\end{array}$ & Zinc and articles thereof \\
\hline
\end{tabular}




\section{ANNEX 2 \\ ESTIMATES OF DETERMINANTS OF TRADE FLOWS}

Bilateral trade patterns are regressed with size and distance between countries in various specifications of the models (see Feenstra 2004, Head and Mayer 2015). In the literature, the best estimation results have been obtained with the Poisson pseudo-maximum likelihood method (PoissonPML), which is robust to different patterns of heteroskedasticity and measurement errors (Santos Silva and Tenreyro, 2006). Also, introducing exporter and importer fixed effects to capture both market-size effects and multilateral-resistance indexes are now common in the equations (Harrigan 1996, Redding and Venables, 2004). Properly defining the multilateral-resistance variables brings the structural dimension as put forward by Anderson and van Wincoop (2003), Anderson and Yotov (2010), and Balistreri and Hillberry (2007) among others.

Moreover, Fally (2015) shows that estimating gravity equation with Poisson PML and fixed effects is consistent with the equilibrium constraints imposed by more structural approaches such as those of Anderson and van Wincoop (2003) and Anderson and Yotov (2010). In particular, the estimated fixed effects in the Poisson PML specification are consistent with the definition of outward and inward multilateral resistance indexes and the equilibrium constraints that they need to satisfy. The Poisson PML estimator is also able to handle the zero bilateral trade flows.

In this study, gravity regressions with fixed effects and Poisson PML are mainly used to estimate the gravity equations; clustered ordinary least squares estimates are also provided for comparisons with literature but with controls for multilateral resistance terms. Following the gravity literature, bilateral trade flows can be expressed as, for each exporter i and importer $\mathrm{j}$, trade flows Xij should satisfy:

$$
X_{i j}=\frac{Y_{i}}{Z_{i}^{-\theta}} * D_{i j}^{-\theta} * \frac{E_{j}}{P_{j}^{-\theta}}
$$

where, Yi refers to total output in country $\mathrm{i}$; Ej refers to total expenditure in country $\mathrm{j}$; Dij captures trade costs from i to j; and the parameter $\theta$ reflects the elasticity of trade flows to trade costs, which may have different structural interpretations depending on the theoretical model (see Head and Mayer, 2015). Finally, the terms $P_{j}^{-\theta}$ and $Z_{i}^{-\theta}$ are the inward and outward "multilateral resistance" indexes as defined by Anderson and van Wincoop (2003). To qualify as structural gravity equations, the two resistance terms should satisfy the following constraints:

$$
P_{j}^{-\theta}=\sum_{i} \frac{Y_{i} D_{i j}^{-\theta}}{Z_{i}^{-\theta}} \quad \text { (2) } \quad \text { and } \quad Z_{j}^{-\theta}=\sum_{j} \frac{E_{i} D_{i j}^{-\theta}}{P_{i}^{-\theta}}
$$

When a log-linear form is estimated, the equation, with additional control variables writes

$$
\ln X_{i j}=a_{0}+a_{1} \ln Y_{i}+a_{2} \ln E_{j}+a_{3} \ln C_{i j}+a_{4} P_{i}+a_{5} Z_{j}+\varepsilon_{i j}
$$

Where $C_{i j}=\delta_{2}$ Distance $_{i j}+\delta_{3}$ CommonBorder $_{i j}+\delta_{4}$ CommonLang $_{i j}+\delta_{5}$ Colony $_{i j}$ and/or $\quad$ other control variables, for instance dummy variable for free trade arrangements.

Estimations with the Poisson pseudo-maximum likelihood estimator are in level and additional variables enter in multiplicative form. 
Table A.2. Estimate results

\begin{tabular}{|c|c|c|c|c|c|}
\hline & (1) & (2) & (3) & (3) & $(4)$ \\
\hline VARIABLES & $x$ & $x$ & $x$ & Ln_X & $X$ \\
\hline \multirow[t]{2}{*}{ Border } & -0.0285 & -0.428 & $0.399^{* * *}$ & $0.626^{\star \star \star}$ & $0.513^{\star * \star}$ \\
\hline & $(6.611 e+06)$ & $(6.590 e+06)$ & $(0.0646)$ & $(0.0861)$ & $(0.0679)$ \\
\hline \multirow[t]{2}{*}{ Common language } & -0.000883 & -0.00468 & 0.0899 & $0.326^{\star \star \star}$ & -0.0682 \\
\hline & $(2.774 \mathrm{e}+06)$ & $(3.430 e+06)$ & $(0.0911)$ & $(0.0685)$ & $(0.0962)$ \\
\hline \multirow[t]{2}{*}{$\begin{array}{l}\text { Lang. spoken by at least } \\
9 \% \text { population }\end{array}$} & -0.00775 & 0.0604 & $0.289^{\star \star \star}$ & $0.287^{\star \star \star}$ & $0.259^{\star *}$ \\
\hline & $(4.492 \mathrm{e}+06)$ & $(4.502 e+06)$ & $(0.0928)$ & $(0.0678)$ & $(0.101)$ \\
\hline \multirow[t]{2}{*}{ Common coloniser } & -0.00194 & 0.108 & 0.207 & $0.937^{\star \star \star}$ & 0.139 \\
\hline & $(726,827)$ & $(690,154)$ & $(0.131)$ & $(0.0581)$ & $(0.143)$ \\
\hline \multirow[t]{2}{*}{ fta_apta } & & $0.177^{\star *}$ & $-0.448^{* *}$ & $-1.822^{* * *}$ & \\
\hline & & $(0.0823)$ & $(0.214)$ & $(0.303)$ & \\
\hline \multirow[t]{2}{*}{ fta_gafta } & & 0.0694 & $-0.852^{* * *}$ & $0.806^{* * *}$ & \\
\hline & & $(0.144)$ & $(0.219)$ & $(0.126)$ & \\
\hline \multirow[t]{2}{*}{ fta_sadc } & & $0.487^{\star *}$ & $2.038^{\star \star \star}$ & $0.965^{\star \star \star}$ & \\
\hline & & $(0.247)$ & $(0.252)$ & $(0.261)$ & \\
\hline \multirow[t]{2}{*}{ fta_mercosur } & & 0.0216 & $0.542^{\star *}$ & $0.750^{\star * *}$ & \\
\hline & & $(0.0948)$ & $(0.236)$ & $(0.233)$ & \\
\hline \multirow[t]{2}{*}{ fta_andean } & & $0.881^{\star \star \star}$ & $0.853^{\star \star \star}$ & $1.527^{\star \star \star}$ & \\
\hline & & $(0.294)$ & $(0.185)$ & $(0.283)$ & \\
\hline \multirow[t]{2}{*}{ fta_comesa } & & 0.215 & $1.716^{\star \star *}$ & $1.265^{\star * *}$ & \\
\hline & & $(0.194)$ & $(0.273)$ & $(0.235)$ & \\
\hline \multirow[t]{2}{*}{ fta_ecowas } & & 0.0131 & $1.827^{\star \star \star}$ & $1.350^{\star \star \star}$ & \\
\hline & & $(0.186)$ & $(0.280)$ & $(0.195)$ & \\
\hline \multirow[t]{2}{*}{ fta_asean } & & -0.0467 & 0.0494 & $-0.640^{* * *}$ & \\
\hline & & $(0.0888)$ & $(0.152)$ & $(0.223)$ & \\
\hline \multirow[t]{2}{*}{ fta_nafta } & & $0.361^{\star \star \star}$ & $0.975^{\star \star \star}$ & $-0.614^{\star *}$ & \\
\hline & & $(0.0560)$ & $(0.105)$ & $(0.300)$ & \\
\hline \multirow[t]{2}{*}{ fta_eu } & & $0.647^{\star \star \star}$ & $0.409^{* \star *}$ & $-0.208^{\star * *}$ & \\
\hline & & $(0.0766)$ & $(0.0894)$ & $(0.0597)$ & \\
\hline \multirow[t]{2}{*}{ fta_wto } & 0.0369 & & & & \\
\hline & $(0.0346)$ & & & & \\
\hline \multirow[t]{2}{*}{ Ln weighted distance } & & & $-0.771^{* * *}$ & $-1.667^{* * *}$ & $-0.851^{\star \star *}$ \\
\hline & & & $(0.0369)$ & $(0.0217)$ & $(0.0305)$ \\
\hline \multirow[t]{2}{*}{ Cost business start-up } & & & & & 0.149 \\
\hline & & & & & (0) \\
\hline \multirow[t]{2}{*}{ Tariff charged } & & & & & $-0.0110^{* *}$ \\
\hline & & & & & $(0.00553)$ \\
\hline \multirow[t]{2}{*}{ Tariff faced } & & & & & -0.00737 \\
\hline & & & & & $(0.00540)$ \\
\hline Country fixed effects & Yes & Yes & Yes & Yes & Yes \\
\hline $\begin{array}{l}\text { Country Pair fixed } \\
\text { effects }\end{array}$ & Yes & Yes & No & & \\
\hline Observations & 527,457 & 527,457 & 559,555 & 372,302 & \\
\hline R-squared & 0.993 & 0.993 & 0.912 & 0.737 & 0.892 \\
\hline
\end{tabular}

Note: ${ }^{* * *} \mathrm{p}<0.01,{ }^{* *} \mathrm{p}<0.05,{ }^{*} \mathrm{p}<0.1$

Source: Cadestin and Fall (2017), "Effectiveness of trade policies in SADC", OECD Working Papers, forthcoming. 
ANNEX 3

\section{PARTICIPATION IN GLOBAL VALUE CHAINS}

Table A.3. The origin of value added in exports - backward participation,

Panel A. SADC countries, intra-regional, 2013

\begin{tabular}{|c|c|c|c|c|c|c|c|c|c|c|c|c|c|c|c|c|}
\hline & & \multicolumn{15}{|c|}{ To } \\
\hline & & AGO & BWA & COD & LSO & MDG & $\mathrm{MOZ}$ & MUS & MWI & NAM & SWZ & SYC & TZA & ZAF & ZMB & ZWE \\
\hline \multirow{17}{*}{ From } & AGO & 0.00 & 0.05 & 0.10 & 0.23 & 0.12 & 0.11 & 0.07 & 0.13 & 0.25 & 0.05 & 0.15 & 0.06 & 0.08 & 0.07 & 0.06 \\
\hline & BWA & 0.01 & 0.00 & 0.10 & 0.65 & 0.04 & 0.05 & 0.01 & 0.43 & 0.10 & 0.02 & 0.06 & 0.02 & 0.00 & 1.27 & 0.77 \\
\hline & COD & 0.04 & 0.05 & 0.00 & 0.20 & 0.07 & 0.11 & 0.03 & 0.14 & 0.04 & 0.05 & 0,14 & 0.05 & 0.08 & 3.62 & 0.05 \\
\hline & LSO & 0.01 & 0.02 & 0.02 & 0.00 & 0.02 & 0.03 & 0.01 & 0.03 & 0.01 & 0.01 & 0.04 & 0.01 & 0.00 & 0.01 & 0.01 \\
\hline & MDG & 0.01 & 0.02 & 0.03 & 0.08 & 0.00 & 0.05 & 0.78 & 0.05 & 0.02 & 0.02 & 0.11 & 0.02 & 0.02 & 0.02 & 0.01 \\
\hline & MOZ & 0.02 & 0.07 & 0.05 & 0.10 & 0.04 & 0.00 & 0.03 & 0.83 & 0.06 & 0.31 & 0.08 & 0.03 & 0.22 & 0.18 & 0.05 \\
\hline & MUS & 0.02 & 0.05 & 0.06 & 0.16 & 2.90 & 0.12 & 0.00 & 0.12 & 0.04 & 0.05 & 1.32 & 0.06 & 0.03 & 0.12 & 0.09 \\
\hline & MWI & 0.01 & 0.06 & 0.03 & 0.16 & 0.03 & 0.31 & 0.02 & 0.00 & 0.03 & 0.04 & 0.07 & 0.20 & 0.10 & 0.25 & 0.17 \\
\hline & NAM & 3.51 & 0.23 & 0.04 & 0.09 & 0.03 & 0.08 & 0.02 & 0.07 & 0.00 & 0.03 & 0.06 & 0.03 & 0.00 & 0.11 & 0.09 \\
\hline & SWZ & 0.04 & 0.01 & 0.02 & 0.25 & 0.05 & 1.50 & 0.06 & 0.24 & 0.01 & 0.00 & 0.07 & 0.07 & 0.00 & 0.06 & 0.10 \\
\hline & SYC & 0.01 & 0.02 & 0.04 & 0.11 & 0.08 & 0.06 & 0.04 & 0.06 & 0.02 & 0.02 & 0.00 & 0.01 & 0.01 & 0.03 & 0.01 \\
\hline & TZA & 0.01 & 0.02 & 0.13 & 0.35 & 0.02 & 0.08 & 0.02 & 0.82 & 0.02 & 0.02 & 0.06 & 0.00 & 0.03 & 0.20 & 0.07 \\
\hline & ZAF & 12.17 & 64.09 & 17.50 & 1.09 & 4.55 & 37.20 & 9.68 & 31.35 & 63.11 & 69.79 & 8.15 & 9.81 & 0.00 & 43.63 & 49.04 \\
\hline & ZMB & 0.77 & 0.24 & 7.54 & 0.31 & 0.08 & 0.21 & 0.07 & 2.27 & 0.19 & 0.18 & 0.17 & 0.45 & 0.73 & 0.00 & 1.16 \\
\hline & ZWE & 0.01 & 0.01 & 0.02 & 0.03 & 0.02 & 0.04 & 0.01 & 0.04 & 0.01 & 0.02 & 0.07 & 0.01 & 0.00 & 0.01 & 0.00 \\
\hline & Domestic & 92.02 & 65.92 & 82.80 & 51.63 & 83.09 & 87.24 & 61.21 & 81.30 & 67.04 & 51.29 & 62.17 & 62.37 & 78.81 & 83.71 & 58.63 \\
\hline & Foreign & 7.98 & 34.08 & 17.20 & 48.37 & 16.91 & 12.76 & 38.79 & 18.70 & 32.96 & 48.71 & 37.83 & 37.63 & 21.19 & 16.29 & 41.37 \\
\hline
\end{tabular}

Panel B. Regional communities, 2013

\begin{tabular}{|c|c|c|c|c|c|c|c|c|c|c|c|c|}
\hline & & \multicolumn{11}{|c|}{ To } \\
\hline & & E28 & ESA & LAT & MEN & NAMR & PAC & ROW & SAS & SADC & SEA & WCA \\
\hline \multirow{13}{*}{ From } & E28 & 53.38 & 28.97 & 21.58 & 43.22 & 19.35 & 16.38 & 52.53 & 25.61 & 37.79 & 17.85 & 40.64 \\
\hline & ESA & 0.05 & 2.27 & 0.04 & 0.11 & 0.02 & 0.06 & 0.16 & 0.12 & 0.29 & 0.03 & 0.48 \\
\hline & LAT & 2.58 & 4.07 & 16.05 & 2.29 & 13.25 & 2.32 & 2.28 & 2.78 & 3.68 & 2.60 & 4.53 \\
\hline & MEN & 4.83 & 8.74 & 2.31 & 8.00 & 3.72 & 2.90 & 3.08 & 7.10 & 5.82 & 6.25 & 4.43 \\
\hline & NAMR & 8.02 & 7.11 & 30.77 & 8.55 & 31.31 & 20.47 & 7.70 & 9.37 & 9.85 & 11.88 & 8.17 \\
\hline & PAC & 0.72 & 2.99 & 0.80 & 1.26 & 1.24 & 8.45 & 0.76 & 3.29 & 2.73 & 3.89 & 1.75 \\
\hline & ROW & 14.12 & 13.12 & 8.98 & 14.61 & 7.61 & 20.17 & 21.44 & 22.63 & 10.79 & 9.11 & 12.77 \\
\hline & SAS & 1.47 & 9.80 & 1.51 & 5.45 & 1.55 & 1.54 & 1.27 & 2.35 & 3.55 & 2.09 & 4.14 \\
\hline & SADC & 0.87 & 5.86 & 0.71 & 0.94 & 0.92 & 0.97 & 0.67 & 1.70 & 8.10 & 1.11 & 2.87 \\
\hline & SEA & 13.45 & 15.97 & 16.81 & 15.27 & 20.24 & 26.56 & 9.62 & 24.63 & 16.83 & 44.91 & 15.56 \\
\hline & WCA & 0.51 & 1.09 & 0.44 & 0.30 & 0.78 & 0.19 & 0.48 & 0.43 & 0.59 & 0.30 & 4.65 \\
\hline & Foreign & 58.42 & 77.96 & 78.10 & 80.89 & 81.17 & 80.62 & 78.06 & 81.65 & 79.89 & 71.50 & 88.92 \\
\hline & Domestic & 41.58 & 22.04 & 21.90 & 19.11 & 18.83 & 19.38 & 21.94 & 18.35 & 20.11 & 28.50 & 11.08 \\
\hline
\end{tabular}

Note: This figure provides a visual representation of backward GVC participation across different countries or regions. Each entry identifies the origin of value added embodied in column nation's gross exports.

Source: Author's calculation based on EORA database. 
ECO/WKP(2017)82

Table A.4 Destination of value added used by trading partners for exports

Panel A: Forward participation, intra-regional, 2013

\begin{tabular}{|c|c|c|c|c|c|c|c|c|c|c|c|c|c|c|c|c|c|c|c|c|}
\hline & & \multicolumn{19}{|c|}{ To } \\
\hline & & AGO & BWA & $C O D$ & LSO & MD & $\mathrm{MO}$ & $M U$ & & MWI & NAM & SWZ & SYC & TZA & ZAF & ZMB & & ZWE & Domestic Fc & eign \\
\hline \multirow{15}{*}{ From } & AGO & 0.00 & & 0.00 & 0.00 & 0.00 & 0.00 & 0.00 & & & & 0.02 & 0.00 & 0.00 & 0.00 & 0.20 & 0.00 & 0.00 & 70.0 & 30.0 \\
\hline & BWA & $0.1=$ & & 0.00 & 0.22 & 0.58 & 0.07 & 0.03 & & & & 0.31 & 0.06 & 0.08 & 0.08 & 0.57 & 4.03 & 0.83 & 76.1 & 23.9 \\
\hline & COD & 0.04 & & 0.01 & 0.00 & 0.02 & & & 0.02 & 0.8 & & 0.02 & & 0.02 & 0.02 & 1.05 & 1.26 & 0.01 & 53.0 & 47.0 \\
\hline & LSO & 0.18 & & 0.09 & 0.10 & 0.00 & 0.08 & 0.04 & 0.14 & & & 0.08 & 0.07 & 0.16 & 0.07 & 0.53 & 0.12 & 0.02 & 72.3 & 27.7 \\
\hline & MDG & 0.0 & & 0.01 & 0.02 & 0.02 & 0.00 & & 1.42 & & & 0.02 & 0.02 & 0.04 & 0.02 & 0.63 & 0.02 & 0.00 & 71.9 & 28.1 \\
\hline & MOZ & 0.12 & & 0.07 & 0.06 & 0.06 & 0.04 & 0.00 & 0.13 & & & & 0.49 & 0.07 & 0.06 & 16.70 & 0.36 & 0.03 & 69.7 & 30.3 \\
\hline & MUS & 0.06 & & 0.03 & 0.04 & 0.04 & 1.52 & 0.02 & 0.00 & & & & & 0.52 & 0.06 & 1.01 & 0.11 & 0.03 & 74.3 & 25.7 \\
\hline & MWI & 0.08 & & 0.06 & 0.05 & 0.09 & 0.03 & & 0.08 & & & & & 0.06 & 0.44 & 7.27 & 0.49 & 0.11 & 71.9 & 28.1 \\
\hline & NAM & 14.96 & & 0.18 & 0.04 & 0.04 & 0.02 & 0.02 & 0.06 & & & 0.00 & & 0.04 & 0.04 & 0.21 & 0.17 & 0.05 & 75.3 & 24.7 \\
\hline & SWZ & 0.44 & & 0.02 & 0.06 & 0.25 & & 0.90 & 0.40 & & & 0.05 & 0.00 & 0.11 & 0.26 & 0.34 & 0.24 & 0.12 & 74.8 & 25.2 \\
\hline & SYC & 0.12 & & 0.04 & 0.08 & 0.09 & 0.14 & 0.03 & 0.27 & & & 0.06 & & 0.00 & 0.05 & 1.00 & 0.09 & 0.02 & 68.6 & 31.4 \\
\hline & TZA & 0.06 & & 0.02 & 0.14 & 0.15 & 0.02 & 0.02 & 0.06 & 0.3 & & & & 0.04 & 0.00 & 1.65 & 0.32 & 0.04 & 74.0 & 26.0 \\
\hline & ZAF & $0.5=$ & & 0.51 & 0.18 & 0.00 & 0.04 & 0.09 & 0.29 & & & & 0.83 & 0.05 & 0.16 & 0.00 & 0.67 & 0.26 & 67.5 & 32.5 \\
\hline & ZMB & 1.04 & & 0.06 & 2.41 & 0.04 & 0.02 & 0.02 & 0.06 & 0.3 & & 0.09 & & 0.03 & 0.23 & 12.64 & 0.00 & 0.19 & 70.9 & 29.1 \\
\hline & ZWE & 0.11 & & 0.04 & 0.05 & 0.05 & 0.07 & 0.03 & 0.13 & & & 0.06 & & 0.16 & 0.07 & 0.51 & 0.07 & 0.00 & 72.0 & 28.0 \\
\hline
\end{tabular}

Panel B: Forward participation, World, 2013

\begin{tabular}{|c|c|c|c|c|c|c|c|c|c|c|c|c|c|c|c|c|}
\hline & & \multicolumn{15}{|c|}{ To } \\
\hline & & E28 & ESA & LAT & MEN & & NAMR & PAC & & SAS & & & SEA & WCA & Domestic F & \\
\hline \multirow{11}{*}{ From } & E28 & 75.5 & & 0.0 & 1.9 & 2.5 & 3. & & 0.4 & 4.8 & 0.7 & 0.5 & 10.0 & 0.1 & 66.5 & 33.5 \\
\hline & ESA & 57.6 & & 1.6 & 2.6 & 4.9 & 3. & & 1.2 & 11.2 & 2.4 & 2.8 & 11.4 & 1.1 & 71.6 & 28.4 \\
\hline & LAT & 38.4 & & 0.0 & 15.3 & 1.4 & 25. & & 0.7 & 2.2 & 0.8 & 0.5 & 15.4 & 0.1 & 77.3 & 22.7 \\
\hline & MEN & 55.5 & & 0.1 & 1.7 & 3.7 & 5. & & 0.6 & 2.3 & 1.5 & 0.6 & 28.4 & 0.1 & 66.4 & 33.6 \\
\hline & NAMR & 39.7 & & 0.0 & 9.7 & 1.7 & 19. & & 1.9 & 2.4 & 0.9 & 0.4 & 23.3 & 0.1 & 73.1 & 26.9 \\
\hline & PAC & 25.6 & & 0.1 & 1.8 & 1.8 & 5. & & 5.7 & 1.7 & 2.2 & 0.9 & 54.5 & 0.1 & 73.9 & 26.1 \\
\hline & ROW & 63.6 & & 0.0 & 2.6 & 2.7 & 4. & & 1.7 & 6.2 & 1.9 & 0.4 & 16.3 & 0.1 & 50.7 & 49.3 \\
\hline & SAS & 48.7 & & 0.2 & 3.2 & 7.4 & 6. & & 1.0 & 2.7 & 1.5 & 1.1 & 27.5 & 0.3 & 73.7 & 26.3 \\
\hline & SADC & 51.6 & & 0.2 & 2.7 & 2.3 & 7. & & 1.1 & 2.5 & 1.9 & 4.4 & 26.0 & 0.3 & 68.1 & 31.9 \\
\hline & SEA & 36.1 & & 0.0 & 2.9 & 1.7 & 6. & & 1.4 & 1.7 & 1.3 & 0.4 & 47.7 & 0.1 & 72.7 & 27.3 \\
\hline & WCA & 61.5 & & 0.1 & 3.4 & 1.5 & 12. & & 0.4 & 3.7 & 1.0 & 0.6 & 14.5 & 1.2 & 66.6 & 33.4 \\
\hline
\end{tabular}

Note: This figure provides a visual representation of forward GVC participation across different countries or regions. Each entry identifies the destination of value added embodied in row nation's gross exports.

Source: Author's calculation based on EORA database. 
ANNEX 4

\section{ROAD INFRASTRUCTURE NEEDS IN SADC}

Figure A.1: Corridors in Southern Africa

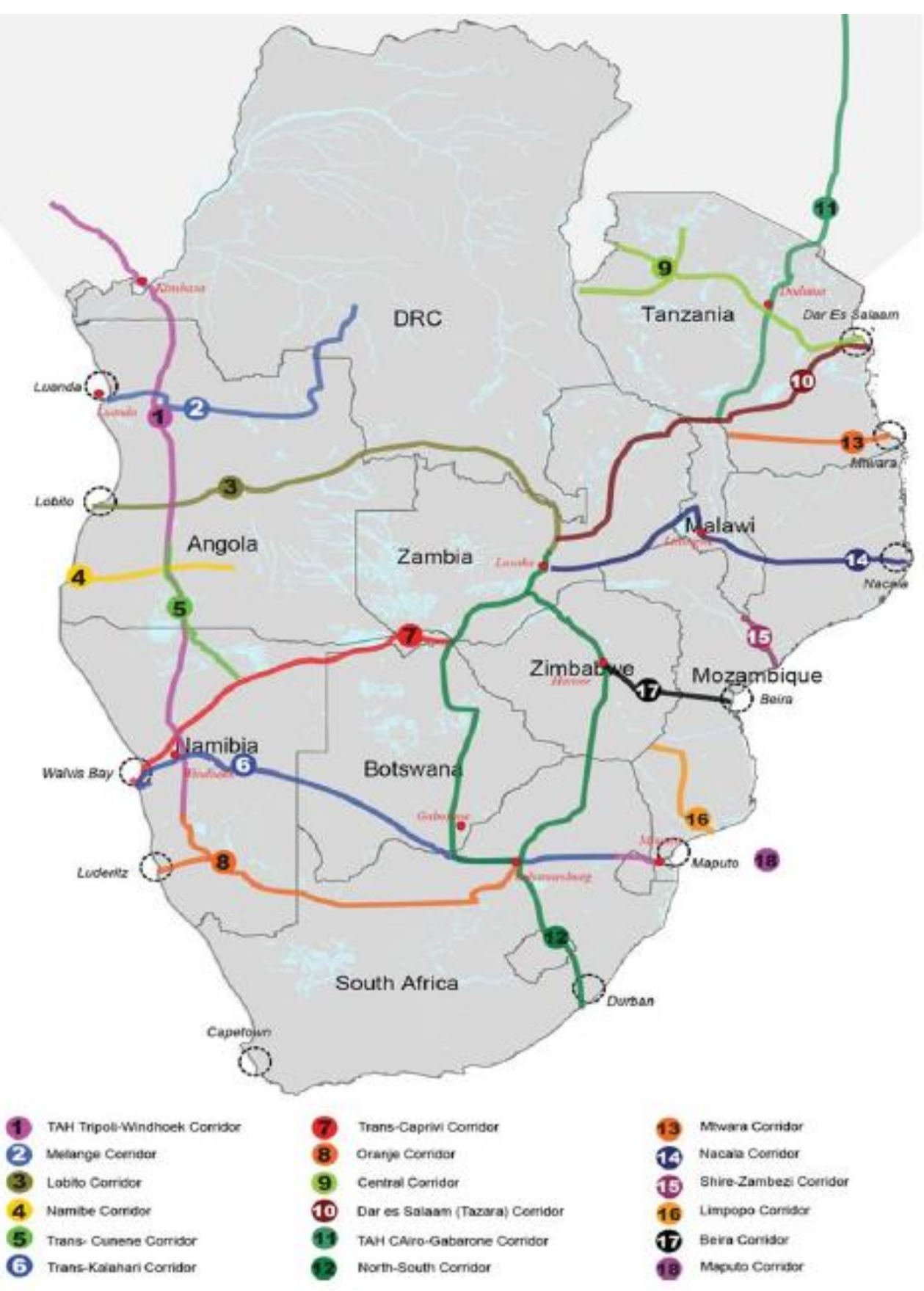

Source: Byiers, B., and J. Vanheukelom (2014), p 7. 
ECO/WKP(2017)82

\section{ANNEX 5}

\section{DETAILED INFORMATION ON TAXES}

\begin{tabular}{|c|c|}
\hline Country & Notes \\
\hline \multicolumn{2}{|l|}{ Payroll Taxes } \\
\hline Angola & In addition to payroll taxes, Angola also has a minimum wage \\
\hline Botswana & Payroll tax of $0.2 \%$ is actually a skills training levy whose base is company turnover \\
\hline DRC & Includes $9 \%$ social security, $2 \%$ employment fund and $0.2 \%$ ONEM \\
\hline Lesotho & No payroll taxes \\
\hline Madagascar & Includes $13 \%$ social security and $5 \%$ for health insurance \\
\hline Malawi & Includes $7.5 \%$ for pension and $1 \%$ TEVETA levy \\
\hline Mauritius & Includes $6 \%$ pension (NPF), $2.5 \%$ savings (NSF) and $1.5 \%$ training tax \\
\hline Mozambique & Contributions are for social security \\
\hline Namibia & Includes social security $0.9 \%$ and workmen's compensation (1-8) \\
\hline Seychelles & Contributions are for pension \\
\hline South Africa & Includes $1 \%$ SDL and $1 \%$ UIF. $1.62 \%$ occupational injuries excluded. \\
\hline Swaziland & Includes $5 \%$ provident fund, $0.46 \%$ min mandatory compensation insurance \\
\hline Tanzania & Includes $5 \%$ SDL, $10 \%$ social security, $1 \%$ workers compensation tariff \\
\hline Zambia & Includes $5 \%$ pension and $4.22 \%$ workers compensation \\
\hline Zimbabwe & Includes $3.5 \%$ social security, $1 \%$ manpower, $0.5 \%$ standards development \\
\hline \multicolumn{2}{|c|}{ Corporate income taxes } \\
\hline Angola & $\begin{array}{l}\text { Mineral Resources: } 25 \% \text { general mining. Oil: } 30 \text { national concessionaire companies, } 50 \% \\
\text { production or sharing agreement, } 65.75 \% \text { foreign and other ventures }\end{array}$ \\
\hline Botswana & $\begin{array}{l}\text { All mining companies taxed at least } 22 \text { per cent, except for diamond companies that are taxed } \\
\text { on a formula basis with rates up to } 55 \% \text {, cannot be less than } 22 \% \text {. Accredited innovation } \\
\text { hubs, IFSC companies taxed and manufacturing companies approved by finance minister } \\
\text { taxed at } 15 \%\end{array}$ \\
\hline DRC & $\begin{array}{l}\text { There is a minimum tax rate of } 1 \% \text { for small companies which also apply to loss making } \\
\text { companies as well as companies with CIT of less than } 1 \% \text { of turnover. }\end{array}$ \\
\hline Madagascar & $\begin{array}{l}\text { Rate of } 20 \% \text { applies to companies with a turnover exceeding MGA } 20 \text { million. } \\
\text { Companies with less subject to CIT of } 5 \% \text { on } 70 \% \text { of turnover, with a minimum tax of MGA } \\
16,000 \text {. Industrial and other exporting service providers eligible for CIT exemption during the } \\
\text { first two to five years and a reduced CIT of } 10 \% \text { thereafter. }\end{array}$ \\
\hline Malawi & $\begin{array}{l}\text { Agricultural and power generation taxed at } 0 \% \text { for first ten years, then } 15 \% \text { if incorporated in } \\
\text { Malawi, else } 20 \% .35 \% \text { for Malawi branches of external companies }\end{array}$ \\
\hline Mauritius & $\begin{array}{l}\text { Banking and telephone service providers liable to additional levy on profits of between 3.4- } \\
5 \% \text {. Companies in freeport export processing zone exempt from taxes. }\end{array}$ \\
\hline Namibia & $\begin{array}{l}\text { Oil and gas extraction: } 35 \% \text {, hard rock and companies rendering mining services: } 37.5 \% \text {, } \\
\text { diamond mining } 55 \% \text {. }\end{array}$ \\
\hline Seychelles & $\begin{array}{l}25 \% \text { on first SCR } 1 \mathrm{~m} \text { and } 30 \% \text { on the remainder except for some financial, telecom and } \\
\text { alcohol companies } 33 \% \text {.International Business Companies (IBCs) tax exempt. }\end{array}$ \\
\hline South Africa & $\begin{array}{l}\text { Special tax regime for small businesses. Gold mining companies taxed using a special } \\
\text { formula. Funds are treated as separate taxpayers and taxed at five separate rates. } 30 \% \\
\text { individual policyholder, } 0 \% \text { untaxed policyholder funds, } 28 \% \text { for the rest. }\end{array}$ \\
\hline Swaziland & $\begin{array}{l}\text { The Minister of Finance, along set guidelines, may nominate a business as a developmental } \\
\text { for a grant with tax concessions such as a lower corporate tax rate }\end{array}$ \\
\hline Tanzania & $\begin{array}{l}5 \% \text { of turnover for technical and management service providers to mining, oil, and gas } \\
\text { entities. } 25 \% \text { for three years for new listings on DSE. } 0.3 \% \text { for companies with perpetual } \\
\text { unrelieved tax losses. Tax holiday in SEZ's only for ten years }\end{array}$ \\
\hline & $\begin{array}{l}\text { Agriculture and agro-processing: 10, export of non-traditional products and production of } \\
\text { organic fertiliser and chemical manufacture of fertiliser }\end{array}$ \\
\hline Zambia & Tax holidays only valid for 5 years, reduce with standard rate kicking in $5-10$ years in \\
\hline & $\begin{array}{l}3 \% \text { AIDS levy imposed on base rate of } 25 \% \text { making effective rate } 25.75 \% \text {. Mining company } \\
\text { holding special lease } 15 \% \text {. Tax holidays in SEZs only valid for } 5 \text { years. }\end{array}$ \\
\hline Zimbabwe & Reduced manufacturing rates apply to companies exporting $\min 30 \%$ of output \\
\hline
\end{tabular}

